\title{
CHARACTERIZATION OF STORMWATER RUNOFF FROM THE NAVAL AIR STATION AND NAVAL WEAPONS INDUSTRIAL RESERVE PLANT, DALLAS, TEXAS, 1994-96
}

By Timothy H. Raines, Stanley Baldys III, and Joy S. Lizarraga

U.S. GEOLOGICAL SURVEY

Open-File Report 97-402

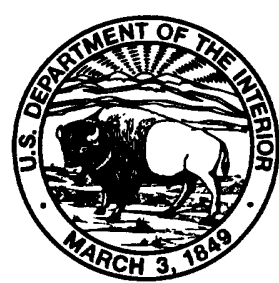

Prepared in cooperation with the SOUTHERN DIVISION NAVAL FACILITIES ENGINEERING COMMAND 2155 EAGLE DRIVE

CHARLESTON, SOUTH CAROLINA 29418 


\section{U.S. DEPARTMENT OF THE INTERIOR \\ BRUCE BABBITT, Secretary}

U.S. GEOLOGICAL SURVEY

Gordon P. Eaton, Director

Any use of trade, product, or firm names is for descriptive purposes only and does not imply endorsement by the U.S. Government.

For additional information write to:

District Chief

U.S. Geological Survey

8011 Cameron Rd.

Austin, TX 78754-3898
Copies of this report can be purchased from:

U.S. Geological Survey

Branch of Information Services

Box 25286

Denver, CO 80225-0286 


\section{CONTENTS}

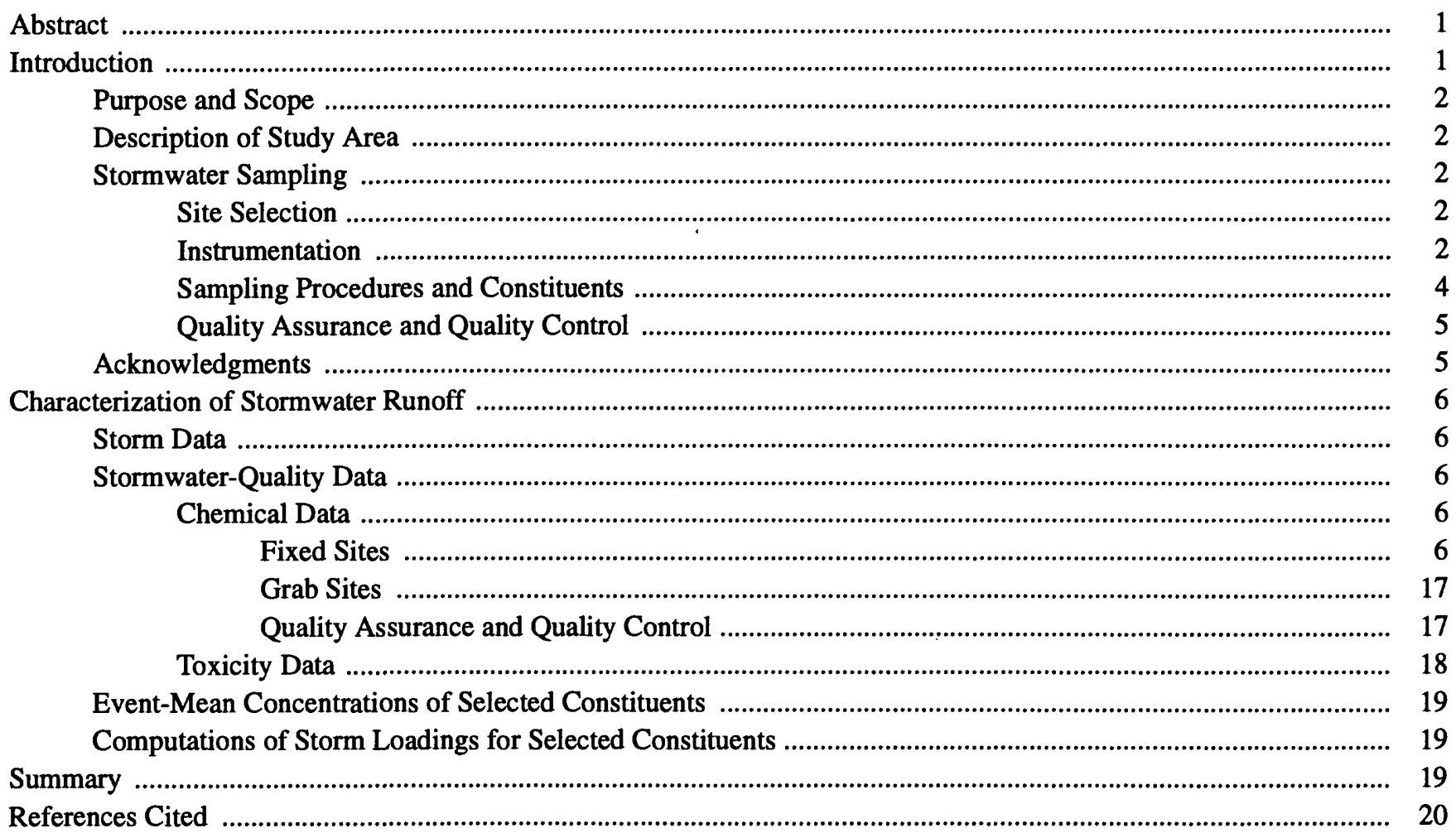

\section{FIGURES}

1. Map showing location of study area and fixed and grab sites

2-6. Hydrographs showing accumulated precipitation, discharge, and times of grab samples and composite aliquots at site:

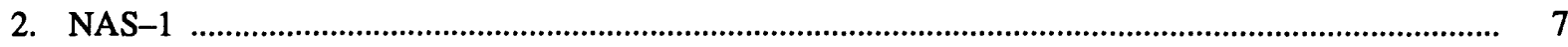

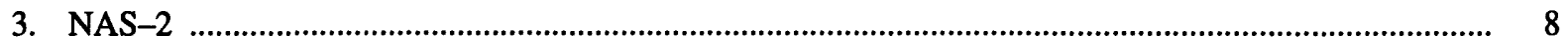

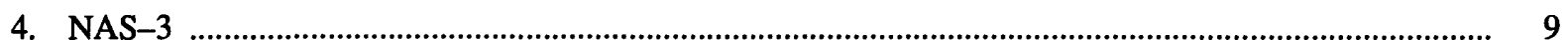

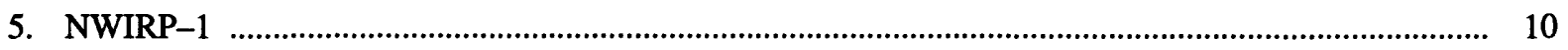

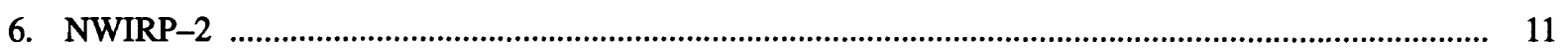

7-10. Boxplots showing range and distribution of:

7. Chemical and biochemical oxygen demand concentrations ............................................................. 12

8. Fecal coliform and fecal streptococcus bacteria densities ............................................................... 12

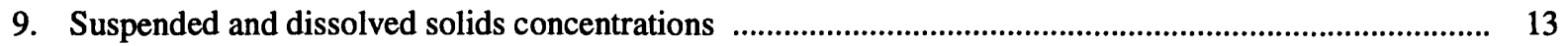

10. Total nitrite plus nitrate and total kjeldahl nitrogen concentrations .................................................. 13

11-12. Graphs showing number of detections for:

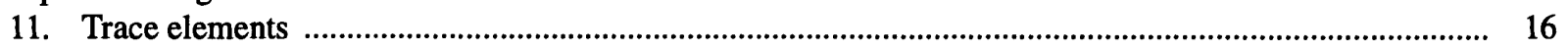

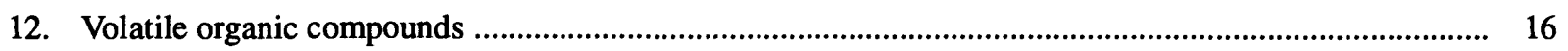

\section{TABLES}

1. Characteristics of sites, Naval Air Station and Naval Weapons Industrial Reserve Plant, Dallas, Texas ........... 4

2. Characteristics of storms and samples collected at fixed sites, Naval Air Station and Naval Weapons Industrial Reserve Plant, Dallas, Texas 
3-7. Stormwater chemical data at site:

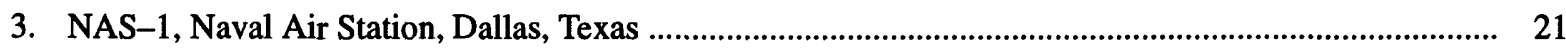

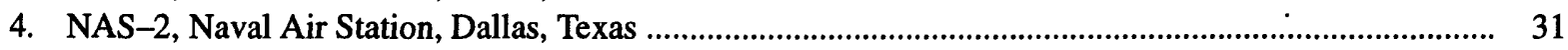

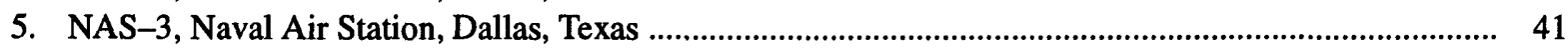

6. NWIRP-1, Naval Weapons Industrial Reserve Plant, Dallas, Texas ................................................. 51

7. NWIRP-2, Naval Weapons Industrial Reserve Plant, Dallas, Texas .................................................... 61

8. Number of trace element, volatile organic compound, semivolatile organic compound, and organophosphorous pesticide detections at fixed sites, Naval Air Station and Naval Weapons Industrial Reserve Plant, Dallas, Texas

9. Number of trace element and volatile organic compound detections that exceed maximum contaminant levels at fixed sites, Naval Air Station and Naval Weapons Industrial Reserve Plant, Dallas, Texas

10. Number of trace element detections that exceed effluent limits for discharge of hazardous metals at fixed sites, Naval Air Station and Naval Weapons Industrial Reserve Plant, Dallas, Texas

11. Number of detections that exceed effluent limits for discharge of water containing other petroleum substances at fixed sites, Naval Air Station and Naval Weapons Industrial Reserve Plant, Dallas, Texas

12. Stormwater chemical data at grab sites, Naval Air Station, Dallas, Texas

13. Number of trace element and volatile organic compound detections at grab sites, Naval Air Station, Dallas, Texas

14. Stormwater toxicity data at fixed sites, Naval Air Station and Naval Weapons Industrial Reserve Plant, Dallas, Texas

15. Median event-mean concentrations of selected constituents at fixed sites, Naval Air Station and Naval Weapons Industrial Reserve Plant, Dallas, Texas 


\title{
Characterization of Stormwater Runoff From the Naval Air Station and Naval Weapons Industrial Reserve Plant, Dallas, Texas, 1994-96
}

\author{
By Timothy H. Raines, Stanley Baldys III, and Joy S. Lizarraga
}

\section{Abstract}

The characterization of stormwater runoff from the Naval Air Station (NAS) and the Naval Weapons Industrial Reserve Plant (NWIRP), Dallas, Texas, is necessary to determine if runoff from the facilities is contributing to off-site contamination of surface waters. A network of five fixed sites and four grab sites was established to collect stormwater-runoff samples from a substantial part of the drainage area of each facility. Fixed sites were instrumented to measure and store precipitation, stage, discharge, and runoff-volume data and to collect flow-weighted composite samples during a storm. Grab and composite samples were collected for six storms at each of the five fixed sites from October 1994 to March 1996. The grab samples were analyzed for about 100 properties and constituents including specific conductance, $\mathrm{pH}$, water temperature, bacteria, trace elements, oil and grease, total phenols, and volatile organic compounds. The composite samples were analyzed for about 220 properties and constituents including specific conductance, $\mathrm{pH}$, chemical oxygen demand, biochemical oxygen demand, major ions, suspended and dissolved solids, nutrients, trace elements, total organic carbon, volatile organic compounds, semivolatile organic compounds, and organochlorine and organophosphorus pesticides. Grab samples were collected for two storms (September 18, 1995, and October 2, 1995) at each of the four grab sites. The grab samples were analyzed for about 80 constituents including specific conductance, $\mathrm{pH}$, water temperature, trace elements, and volatile organic compounds. Com- posite samples were collected for two of the six storms sampled at the fixed sites and analyzed for aquatic toxicity. Fathead minnow growth and survival toxicity tests and water flea reproduction and survival toxicity tests were done.

Median event-mean concentrations computed for 12 selected constituents in samples from NAS and NWIRP fixed sites were compared to median event-mean concentrations for residential, commercial, industrial, and highway land uses within the Dallas-Fort Worth area computed from data collected for the National Pollutant Discharge Elimination System program. NAS and NWIRP median event-mean concentrations also were compared to those for residential and commercial land uses from the Nationwide Urban Runoff Program.

\section{INTRODUCTION}

The U.S. Department of Defense is concerned about the past and present environmental impacts of stormwater runoff from the Naval Air Station (NAS) and the adjacent Naval Weapons Industrial Reserve Plant (NWIRP), Dallas, Texas, to receiving waters and ecosystems. Most runoff from the NAS and the NWIRP drains into Mountain Creek Lake. Stormwater runoff is suspected of being a major mechanism of off-site contaminant transport from the two facilities.

In 1994 the U.S. Geological Survey (USGS), in cooperation with the Southern Division Naval Facilities Engineering Command, began a study to characterize the stormwater runoff from the NAS and NWIRP. A stormwater sampling program was conducted from October 1994 to March 1996. Several concurrent studies of the quality of sediment suspended in runoff and on the lake bottom and the quality of ground water are being done in the study area. 


\section{Purpose and Scope}

This report characterizes stormwater runoff originating from the drainage areas of nine sites at the NAS and NWIRP. The report is limited to analysis of chemical and toxicity (to aquatic organisms) data for stormwater runoff collected from October 1994 to March 1996. Grab and flow-weighted composite samples were collected at each of five fixed sites on the NAS and NWIRP during six storms and analyzed for about 100 properties and constituents in grab samples and about 220 properties and constituents in composite samples. Grab samples were collected at each of four grab sites on the NAS during two storms and analyzed for about 80 properties and constituents. Additional composite samples were collected at each of the five fixed sites during two of the six storms and analyzed for aquatic organism toxicity. Median event-mean concentrations (EMCs) were calculated for 12 selected constituents for the fixed sites.

\section{Description of Study Area}

The study area is in north-central Texas in Dallas County in the city of Dallas (fig. 1). The NWIRP is immediately adjacent to and west of the NAS. Both facilities are adjacent to and north of Mountain Creek Lake. Most runoff from the NAS and NWIRP drains into Mountain Creek Lake.

The study area has a moderate climate with hot, dry summers; warm, wet autumns; cool, dry winters; and warm, wet springs. Mean annual temperature for the study area is 64 degrees Fahrenheit $\left({ }^{\circ} \mathrm{F}\right)$ with monthly means ranging from $44^{\circ} \mathrm{F}$ in January to $86^{\circ} \mathrm{F}$ in July. Mean annual precipitation, mostly as rainfall, is 29.5 inches (in.) (U.S. Department of Commerce, National Oceanic and Atmospheric Administration, 1990).

Soils in the study area consist mainly of the Houston Black-urban land complex. This complex is made up of deep, moderately well drained, gently sloping clay soils and areas of urban land. Houston Black soil represents about 40 percent of the land area; urban land, which consists of areas of buildings and pavement, represents about 35 percent; and minor soils represent the other 25 percent. A representative soil profile of the Houston Black consists of 6 in. of very dark gray clay overlying 38 in. of black clay. The permeability of the Houston Black soil is very low (U.S. Department of Agriculture, Soil Conservation Service, 1980).
Land cover is characterized by a variety of military land uses. The NAS land cover consists of runways, hangars, offices or commercial buildings, aircraft maintenance and automotive shops, barracks or high-density residential housing, and several paved roads. The NWIRP land cover consists primarily of industrial buildings (used for manufacturing aircraft and weapons) and paved areas.

\section{Stormwater Sampling}

A network of five fixed sites and four grab sites was established to collect stormwater samples to be analyzed for constituents that characterize the physical, organic, and inorganic chemical quality of the stormwater runoff. The five fixed sites were instrumented with equipment to measure and store 1-minute values of precipitation, stage, discharge, and runoff volume and to collect automatic flow-weighted composite samples during a storm. Grab and composite samples were collected for six storms at each of the five fixed sites. Grab samples were collected manually for two storms at each of the four grab sites (outfalls). Additional composite samples were collected for two of the six storms at each of the five fixed sites and analyzed for aquatic organism toxicity.

\section{Site Selection}

Five fixed stormwater-sampling sites were established; three on the NAS and two on the NWIRP (fig. 1). These sites were located to measure runoff from a major percentage of the drainage area of each facility. Three of the five outfalls drain into Mountain Creek Lake (NAS-1, NWIRP-1, NWIRP-2). Four additional stormwater outfalls were selected at the NAS for collecting grab samples (fig. 1). The stormwater outfalls at all four grab sites discharge into Mountain Creek Lake. A fifth grab site at the NAS initially was identified for sampling but later was determined to be an abandoned sanitary sewer outfall. Characteristics of fixed and grab sites are listed in table 1.

\section{Instrumentation}

The five fixed sites were instrumented for automatic collection of stormwater samples. A 4- by 3- by 4-foot (ft) metal gage house was installed at each site to hold the sampling equipment and supplies. Precipitation, in 0.01 -in. increments, was measured by a tipping bucket raingage that was attached to the gage house. The water elevation (stage) in a culvert or drainage 


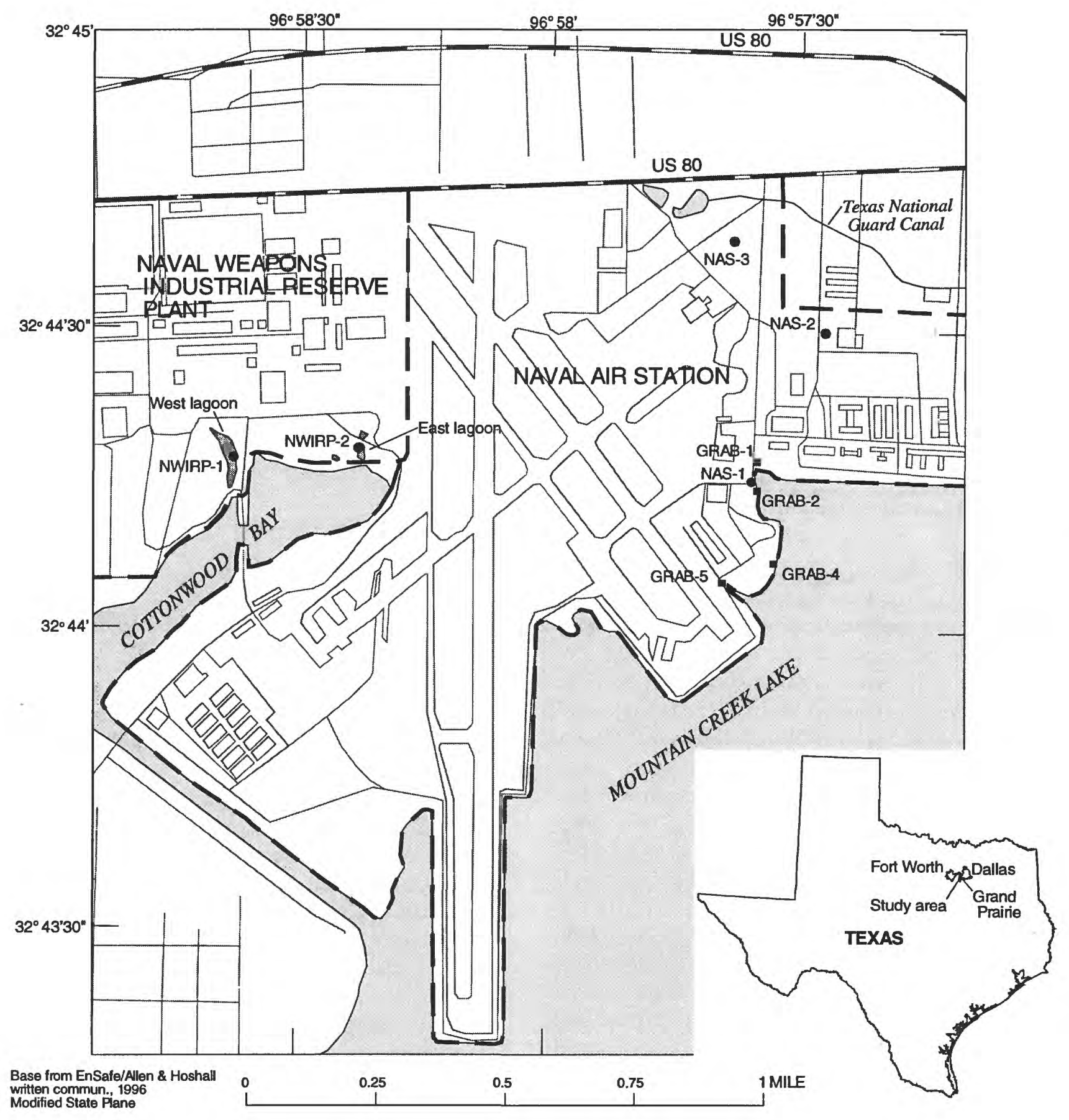

EXPLANATION

Boundary of Naval Air Station and Naval
Weapons Industrial Reserve Plant

- Fixed site

- Grab site

Figure 1. Location of study area and fixed and grab sites. 
Table 1. Characteristics of sites, Naval Air Station and Naval Weapons Industrial Reserve Plant, Dallas, Texas

[in., inches; RCP, round concrete pipe; TANG, Texas Air National Guard; --, not applicable; CMP, composite pipe]

\begin{tabular}{|c|c|c|c|c|c|c|}
\hline $\begin{array}{c}\text { Station } \\
\text { no. }\end{array}$ & $\begin{array}{c}\text { Station } \\
\text { name }\end{array}$ & Latitude & Longitude & $\begin{array}{l}\text { Estimated } \\
\text { drainage } \\
\text { area } \\
\text { (acres) } 1\end{array}$ & $\begin{array}{l}\text { Outfall } \\
\text { type }\end{array}$ & $\begin{array}{l}\text { Primary } \\
\text { land } \\
\text { use }^{1}\end{array}$ \\
\hline \multicolumn{7}{|c|}{ Fixed sites } \\
\hline 08050040 & NAS-1 & $32^{\circ} 44^{\prime} 15^{\prime \prime}$ & $96^{\circ} 57^{\prime} 36^{\prime \prime}$ & 28.4 & 36-in. RCP & hangar and runway \\
\hline 08050150 & NAS-2 & $32^{\circ} 44^{\prime} 30^{\prime \prime}$ & $96^{\circ} 57^{\prime} 27^{\prime \prime}$ & 22.5 & 42-in. RCP & fuel farm, commercial \\
\hline 08050148 & NAS-3 & $32^{\circ} 44^{\prime} 39^{\prime \prime}$ & $96^{\circ} 57^{\prime} 38^{\prime \prime}$ & 89.8 & natural channel & TANG hangar and runway, commercial \\
\hline 08050012 & NWIRP-1 & $32^{\circ} 44^{\prime} 17^{\prime \prime}$ & $96^{\circ} 58^{\prime} 38^{\prime \prime}$ & 187.6 & lagoon & industrial \\
\hline 08050010 & NWIRP-2 & $32^{\circ} 44^{\prime} 18^{\prime \prime}$ & $96^{\circ} 58^{\prime} 23^{\prime \prime}$ & 113.5 & lagoon & industrial \\
\hline \multicolumn{7}{|c|}{ Grab sites } \\
\hline -- & GRAB-1 & $32^{\circ} 44^{\prime} 17^{\prime \prime}$ & $96^{\circ} 57^{\prime} 35^{\prime \prime}$ & 4.6 & 36-in. RCP & commercial \\
\hline -- & GRAB-2 & $32^{\circ} 44^{\prime} 14^{\prime \prime}$ & $96^{\circ} 57^{\prime} 35^{\prime \prime}$ & 2.5 & 30-in. RCP & commercial \\
\hline -- & GRAB-4 & $32^{\circ} 44^{\prime} 07^{\prime \prime}$ & $96^{\circ} 57^{\prime} 33^{\prime \prime}$ & 7.4 & 36-in. RCP & runway, commercial \\
\hline -- & GRAB-5 & $32^{\circ} 44^{\prime} 05^{\prime \prime}$ & $96^{\circ} 57^{\prime} 39^{\prime \prime}$ & 53.3 & 30- by 48 -in. CMP & runway \\
\hline
\end{tabular}

${ }^{1}$ From drainage maps, Ensafe/Allen \& Hoshall, Memphis, Tenn.

channel was measured with a Campbell SWD1 monitoring system, which uses a self-calibrating pressure transducer and gas bubbler. The discharge was computed using the measured stage and a theoretical equation based on the type of flow-control structure in the culvert or drainage channel: A sharp-crested trapezoidal weir was installed at site NWIRP-1, existing concrete broad-crested weirs were used at sites NWIRP-2 and NAS-3, and Palmer-Bowlus flumes were installed in the culverts at sites NAS-1 and NAS-2. The accumulated runoff volume, in cubic feet, was computed by multiplying the discharge, in cubic feet per second, by the time step, in seconds. The SWD1 system triggered an ISCO 3700 automatic sampler to collect a volumeweighted composite sample after a prespecified volume of flow had passed the flow-control structure. The sampler line was teflon-lined tubing connected to a stainless steel intake. The time, stage, precipitation, discharge, accumulated runoff volume, and composite sample times are stored in the Campbell CR-10 datalogger. The site is powered by a deep-cycle 12-volt battery recharged by a solar panel. A storage module is used for data backup in the event of power failure. Telephone communication was established to all sites to provide remote monitoring and data retrieval.

\section{Sampling Procedures and Constituents}

Stormwater samples were collected and analyzed only when the following precipitation criteria were met:
(1) Storm could not be preceded by more than $0.1 \mathrm{in}$. of precipitation in the last 72 hours, and (2) storm had to have a total precipitation of at least 0.1 in.

Grab and composite samples were collected for six storms at each of the five fixed sites. The grab samples were collected as soon as possible after flow passed the flow-control structure. Sample bottles were filled by dipping the bottles into the flowing water by hand or by pumping water from the sampling line using a portable peristaltic pump if safety considerations prohibited hand sampling. The grab samples were analyzed for about 100 properties and constituents including specific conductance, $\mathrm{pH}$, water temperature, bacteria, selected trace elements, oil and grease, total phenols, and selected volatile organic compounds (VOCs). The grab samples were analyzed for these constituents for two principal reasons: (1) The tendency of some of these constituents to have varying concentrations after a short period of time (generally less than 3 hours) because of changing equilibriums, and (2) to characterize the firstflush phase of runoff for comparison to the composite sample.

Flow-weighted composite samples were collected by automatic samplers and by hand. The automatic samplers were triggered by the datalogger to pump equal volumes (aliquots) for a specified volume of runoff for the duration of the storm (automatic composite aliquots). The hand-dipped composite aliquots were collected discretely by hand when the sampler 
triggered and later composited at the laboratory. The composite sample was analyzed for about 220 properties and constituents including specific conductance, $\mathrm{pH}$, chemical oxygen demand (COD), biochemical oxygen demand (BOD), major ions, suspended and dissolved solids, selected nutrients, selected trace elements, total organic carbon, VOCs, semivolatile organic compounds (SVOCs), organochlorine pesticides, polychlorinated biphenyls, and organophosphorus pesticides. The hand-dipped composite aliquots were used for analysis of VOCs and toxicity. The automatic composite aliquots were used for analysis of the remaining constituents.

Grab samples were measured for specific conductance, $\mathrm{pH}$, and temperature in the field during the storm. Grab samples were analyzed for bacteria (fecal coliform and fecal streptococcus), and composite samples were analyzed for specific conductance, $\mathrm{pH}$, alkalinity, and BOD at the USGS Fort Worth Subdistrict laboratory. Grab samples were analyzed for oil and grease and total phenols, and composite samples were analyzed for COD, major ions, suspended and dissolved solids, total organic carbon, and SVOCs at the USGS National Water Quality Laboratory (NWQL) in Arvada, Colo. Grab samples were analyzed for trace elements and VOCs, and composite samples were analyzed for nutrients, trace elements, VOCs, and organochlorine and organophosphorus pesticides at Quanterra Laboratory in Arvada. The grab and composite samples collected at each of the five sites during the last two storms were analyzed for trace elements and VOCs at the NWQL.

Grab samples were collected at each of the four grab sites during two storms and were analyzed for about 80 constituents including specific conductance, $\mathrm{pH}$, water temperature, trace elements, and VOCs. The grab samples were collected by hand at the outfall. Specific conductance, $\mathrm{pH}$, and temperature were measured in the field during the storm, and trace elements and VOCs were analyzed at the NWQL.

Additional composite samples were collected during two of the six storms at the fixed sites and analyzed for toxicity to aquatic organisms. Two ambient toxicity tests were used: 7-day fathead minnow (Pimephales promelas) growth and survival tests, and 7-day water flea (Ceriodaphnia dubia) larval reproduction and survival tests. The hand-dipped composite aliquots for toxicity analysis were composited and analyzed at the Bio-Aquatic Testing Laboratory in Carrolton, Tex.

\section{Quality Assurance and Quality Control}

Stormwater sampling followed prescribed field and laboratory procedures outlined in a sampling and analysis plan approved by the Texas Natural Resource Conservation Commission (TNRCC). Strict qualityassurance and quality-control (QA/QC) procedures were followed during the study. Chain-of-custody forms were used for processing and shipment of samples. Field blanks ${ }^{1}$ were used to test the sampling equipment for organic contamination. Trip blanks ${ }^{2}$ were used to determine if contamination of the VOC samples occurred during transit, and laboratory blanks were used to determine if contamination of the organic samples occurred in the field laboratory during sample compositing. Replicate samples (collected at the same time and using the same protocols as the environmental samples) were collected to check the precision of the laboratory analyses. Spike samples ${ }^{3}$ were used to determine the extent, if any, of the effect of the sample matrix on the accuracy of the analysis. Reference samples (nutrient and inorganic constituents with known concentrations) were used to determine the analytical accuracy of the laboratory. The NWQL, Quanterra Laboratory, and Bio-Aquatics Testing Laboratory followed similar QA/QC procedures.

\section{Acknowledgments}

Jay Spence, Ensafe/Allen \& Hoshall, provided drainage maps for the NAS and NWIRP. The toxicity results were analyzed by J. Bruce Moring, USGS. The following USGS employees collected and processed stormwater samples during this study: Jack D. Benton, Martin J. Danz, Bruce R. Goddard, Bradley L. Mansfield, Darryl G. Pinion, Jeffrey T. Sandlin, Clyde T. Schoultz, J.M. Taylor, and David V. Tudor, Jr.

\footnotetext{
${ }^{1} \mathrm{~A}$ constituent-free solution that is subjected to all aspects of sample collection, field processing, preservation, transportation, and laboratory handling as an environmental sample.

${ }^{2} \mathrm{~A}$ constituent-free solution that is put in the same type of bottle used for an environmental sample and kept with the set of sample bottles both before and after sample collection.

${ }^{3}$ A sample to which known concentrations of specific constituents have been added in such a manner as to minimize the change in the matrix of the original sample.
} 


\section{CHARACTERIZATION OF STORMWATER RUNOFF}

\section{Storm Data}

Water samples were collected for six storms at each of the five fixed stormwater monitoring sites from October 1994 to March 1996. The storm characteristics are listed in table 2 . Of the 30 storms, 12 storms were sampled in the fall months of September through November, 6 storms were sampled in the winter months of December through February, 12 storms were sampled in the spring months of March through May, and no storms were sampled during the summer months of June through August. More than one-half of the 30 samples were collected in March (9) and November (7). The total precipitation per storm ranges from 0.12 to 1.58 in., and the maximum 5-minute intensity ranges from 0.03 to $0.43 \mathrm{in}$. for the 30 storms. The antecedent dry period ranges from 3 to 17 days. The runoff duration ranges from 70 to 515 minutes, and total runoff ranges from 7,050 to 518,000 cubic feet $\left(\mathrm{ft}^{3}\right)$. The number of automatic composite aliquots ranges from 2 to 33 , and the number of hand-dipped composite aliquots ranges from 2 to 15 .

The hydrographs for the 30 storms are shown in figures 2-6. The hydrographs show the accumulated precipitation, discharge, and grab and composite sample times for each storm.

\section{Stormwater-Quality Data}

Water samples for chemical analysis were collected for six storms at each of the five fixed sites and two storms at each of the four grab sites. Water samples for toxicity analysis were collected for two of the six storms at each of the five fixed sites.

\section{Chemical Data}

\section{Fixed Sites}

The stormwater-quality data at the five fixed sites are listed in tables 3-7 (at end of report). Specific conductance at the five sites ranges from 54 to 1,160 microsiemens per centimeter at 25 degrees Celsius $(\mu \mathrm{S} / \mathrm{cm})$ in the grab samples and from 27 to $401 \mu S / \mathrm{cm}$ in the composite samples. The $\mathrm{pH}$ ranges from 6.8 to 8.3 in the grab samples and from 6.6 to 8.0 in the composite samples. Specific conductance and $\mathrm{pH}$ generally are larger in the grab samples than in the composite samples at the five sites. Water temperature ranges from 9.0 degrees
Celsius $\left({ }^{\circ} \mathrm{C}\right)$ for the storm sampled on March 27, 1996, to $27.5^{\circ} \mathrm{C}$ for the storm sampled on September 18 , 1995. Boxplots showing range and distribution of COD and BOD for the five sites (fig. 7) indicate that COD ranges from 11 to 110 milligrams per liter $(\mathrm{mg} / \mathrm{L})$ and BOD ranges from 1.0 to $19 \mathrm{mg} / \mathrm{L}$. Median COD and BOD are largest at site NAS-2. Hardness ranges from 11 to $120 \mathrm{mg} / \mathrm{L}$ as calcium carbonate $\left(\mathrm{CaCO}_{3}\right)$, and alkalinity ranges from 12 to $150 \mathrm{mg} / \mathrm{L}$ as $\mathrm{CaCO}_{3}$ at the five sites. Hardness and alkalinity are smallest at site NAS-1 and largest at site NWIRP-2.

Boxplots showing range and distribution of fecal coliform and fecal streptococcus bacteria densities indicate large variations at each of the five sites (fig. 8). The largest range in fecal coliform density, 860 to 900,000 colonies per 100 milliliters (cols. $/ 100 \mathrm{~mL}$ ), is at site NAS-2. The largest range in fecal streptococcus density, 320 to $1,700,000$ cols. $/ 100 \mathrm{~mL}$, is at site NAS-1. The largest median bacteria densities are at site NAS -2 , and the smallest median bacteria densities are at site NWIRP-2. Median fecal coliform densities are comparable to the fecal streptococcus densities at each of the five sites.

Major ions in the composite samples primarily are calcium, sodium, and sulfate (tables 3-7). On the basis of anion and cation balances from the laboratory analyses, the stormwater type primarily is calcium carbonate.

The suspended solids and dissolved solids concentrations range from less than the analytical detection limit of 1 to $192 \mathrm{mg} / \mathrm{L}$ and from 17 to $242 \mathrm{mg} / \mathrm{L}$, respectively, at the five sites (tables 3-7). Boxplots showing range and distribution of suspended and dissolved solids (fig. 9) indicate that the largest range in suspended solids concentrations is at site NAS- 3 and the largest range in dissolved solids concentrations is at site NWIRP-2. The median dissolved solids concentrations are greater than median suspended solids concentrations for each of the five sites.

Concentrations of total nitrite plus nitrate nitrogen range from 0.059 to $1.4 \mathrm{mg} / \mathrm{L}$ (tables 3-7), and concentrations of total Kjeldahl nitrogen range from less than the analytical detection limit of 0.5 to $2.9 \mathrm{mg} / \mathrm{L}$ at the five sites (tables 3-7). Boxplots showing range and distribution of total nitrite plus nitrate and total Kjeldahl nitrogen (fig. 10) indicate that the largest range in total nitrite plus nitrate nitrogen concentrations is at site NAS-3 and the largest range in total Kjeldahl nitrogen concentrations is at site NAS-2. Median concentrations of total nitrite plus nitrate and total Kjeldahl nitrogen 

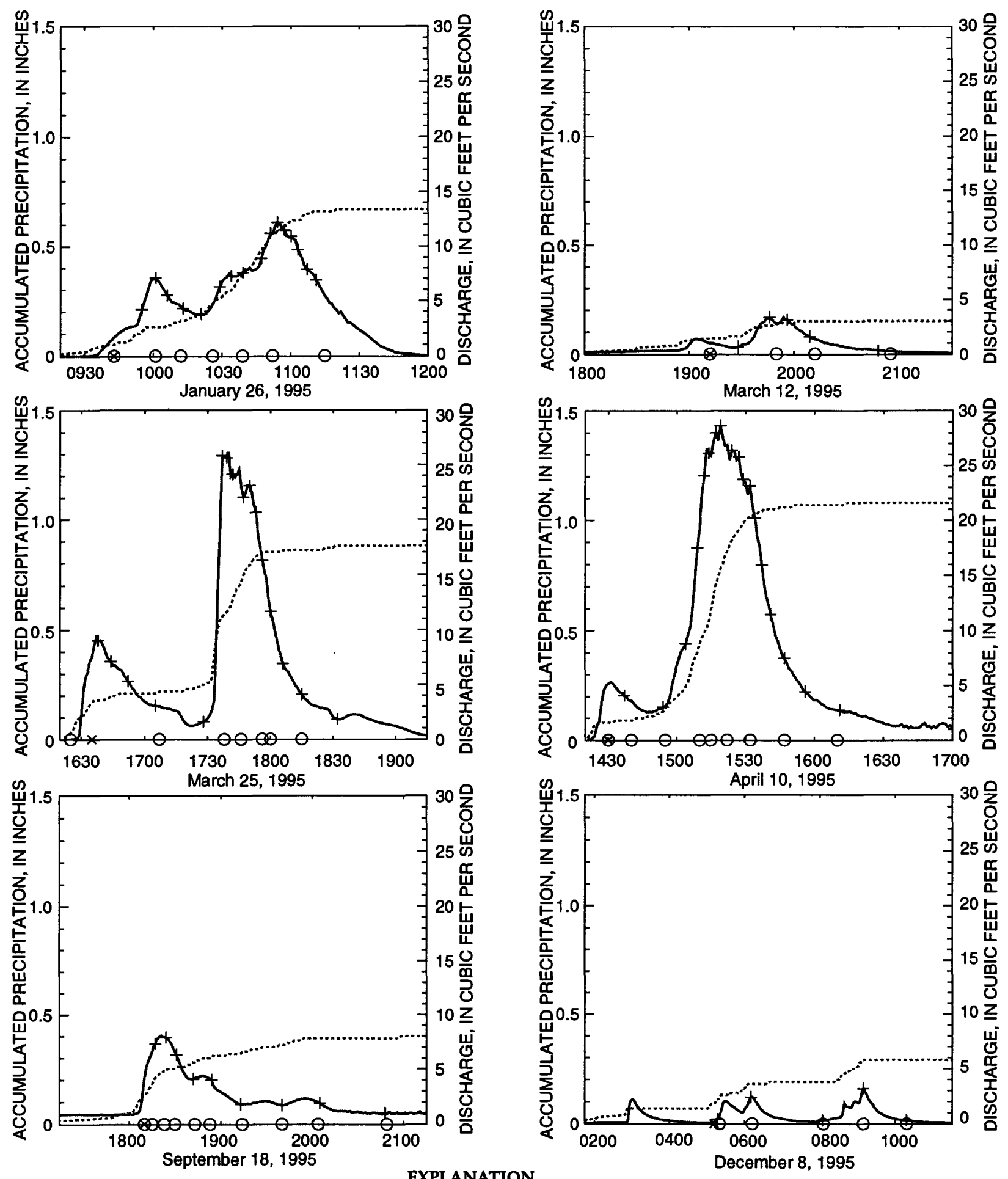

EXPLANATION

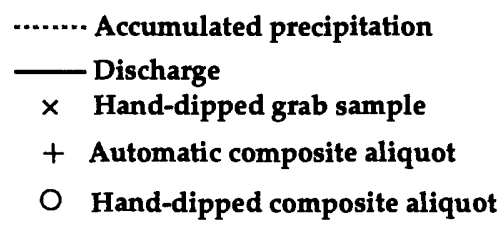

Figure 2. Hydrographs showing accumulated precipitation, discharge, and times of grab samples and composite aliquots at site NAS-1. 

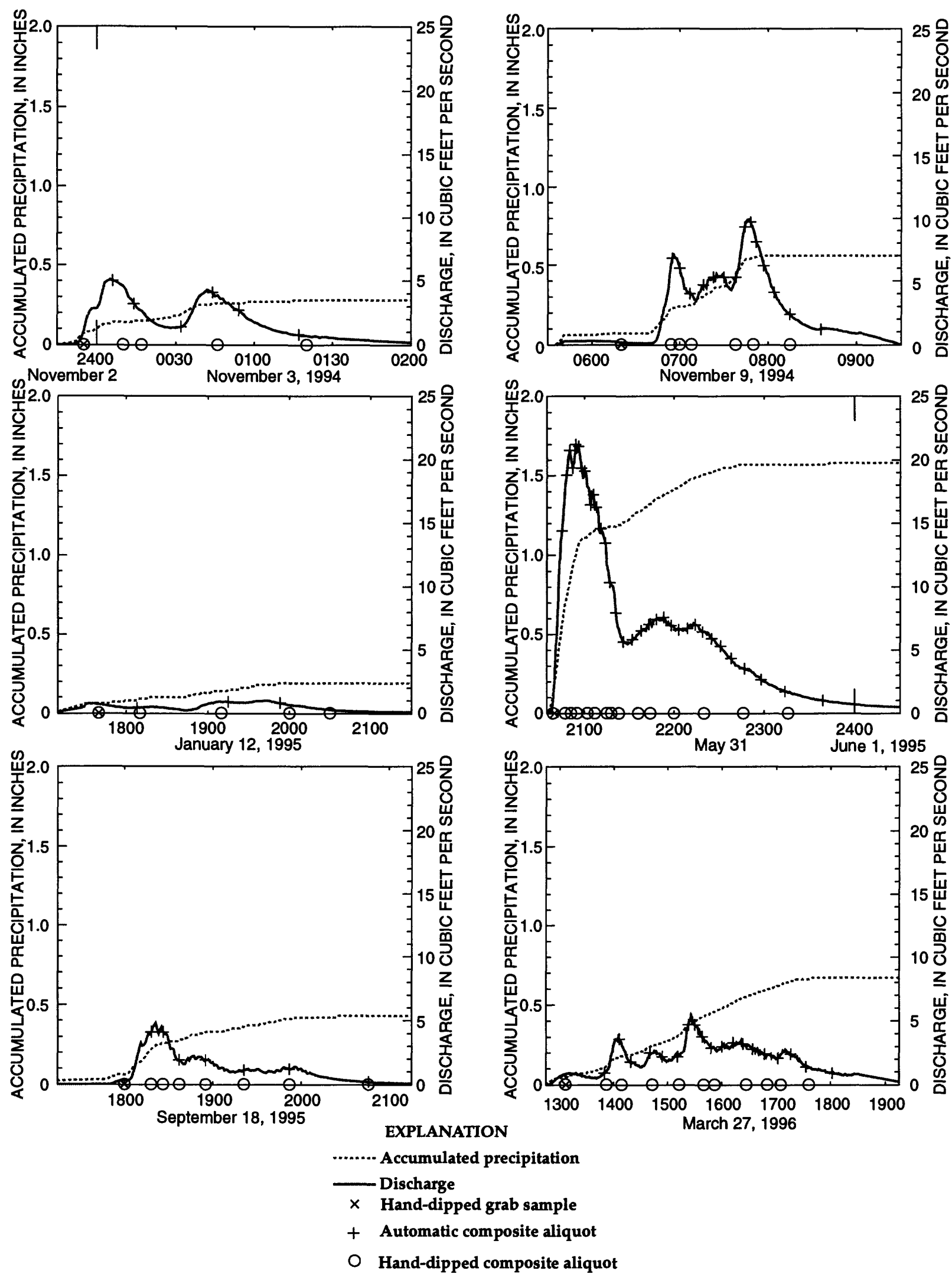

Figure 3. Hydrographs showing accumulated precipitation, discharge, and times of grab samples and composite aliquots at site NAS-2. 

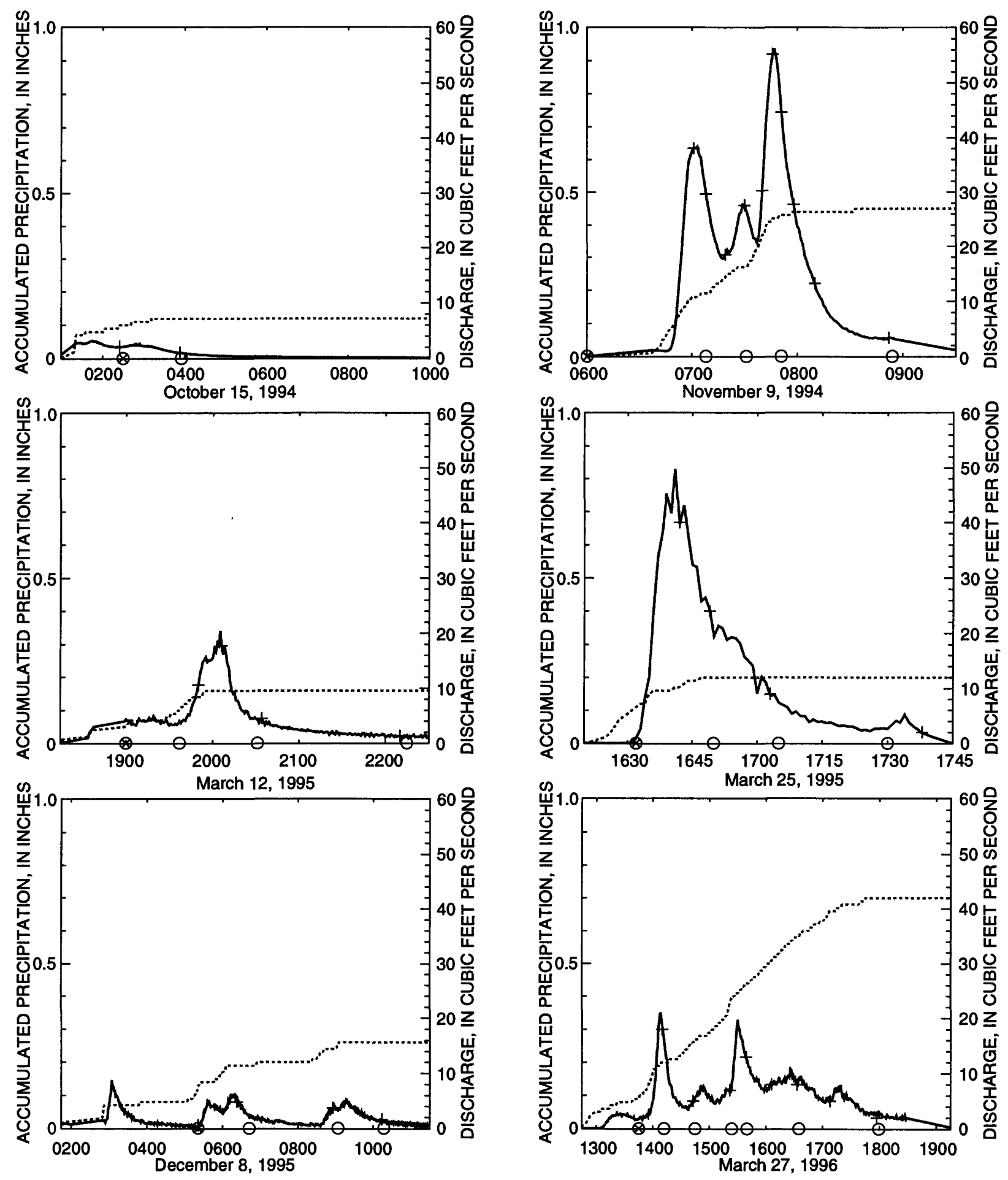

EXPLANATION

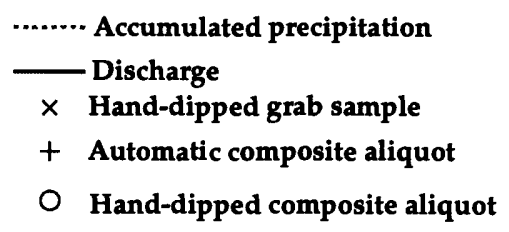

Figure 4. Hydrographs showing accumulated precipitation, discharge, and times of grab samples and composite aliquots at site NAS-3. 

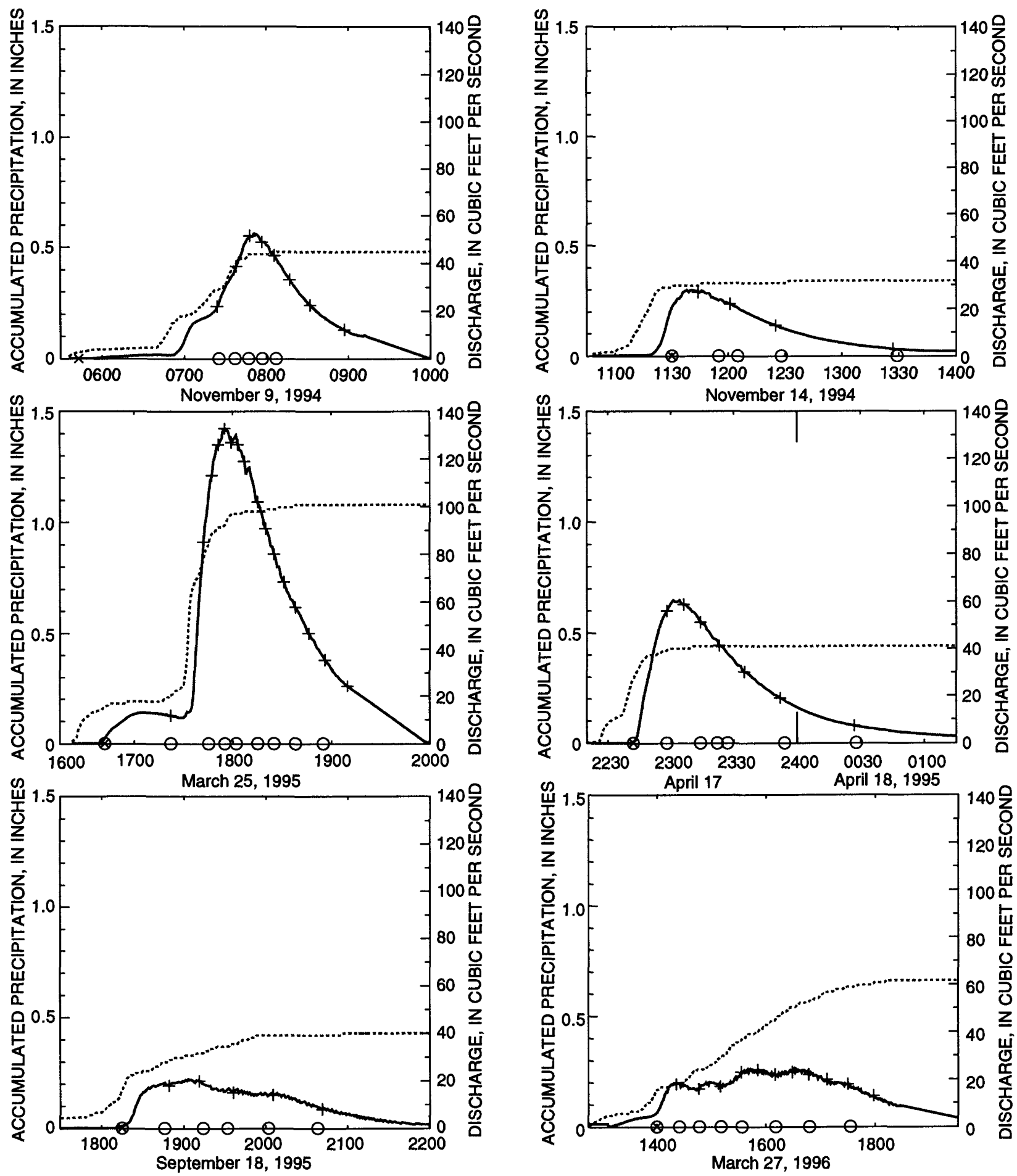

\section{EXPLANATION}

March 27, 1996

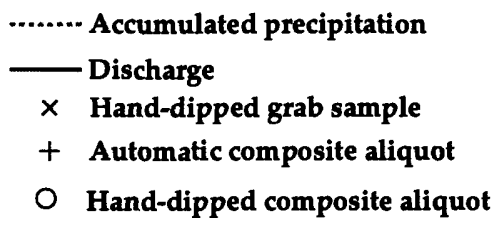

Figure 5. Hydrographs showing accumulated precipitation, discharge, and times of grab samples and composite aliquots at site NWIRP-1. 

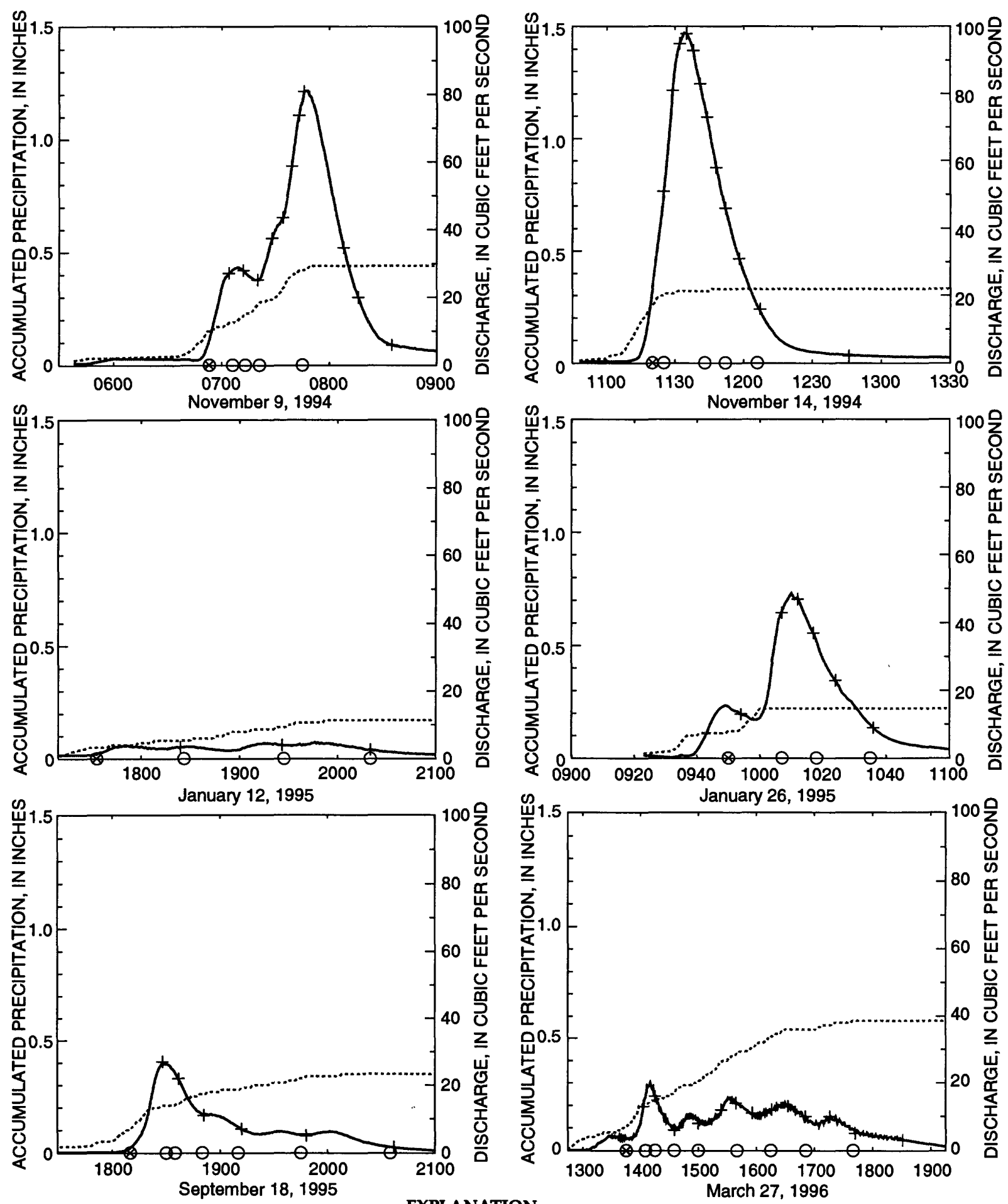

\section{EXPLANATION}

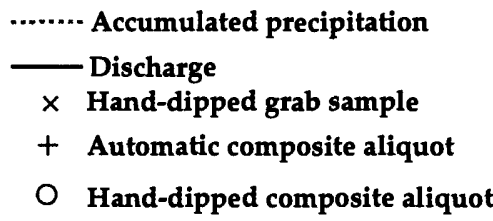

Figure 6. Hydrographs showing accumulated precipitation, discharge, and times of grab samples and composite aliquots at site NWIRP-2. 


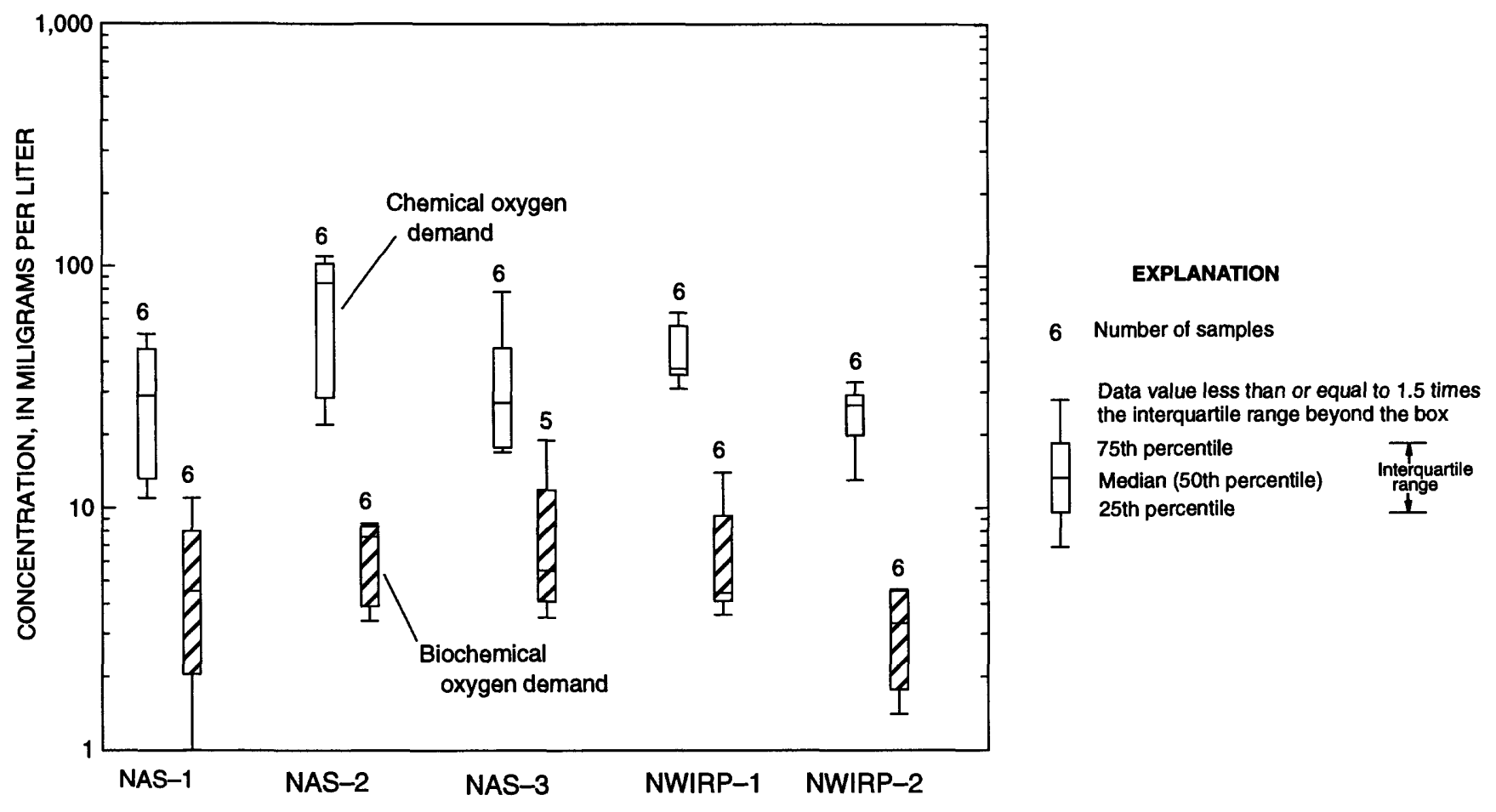

Figure 7. Range and distribution of chemical and biochemical oxygen demand concentrations.

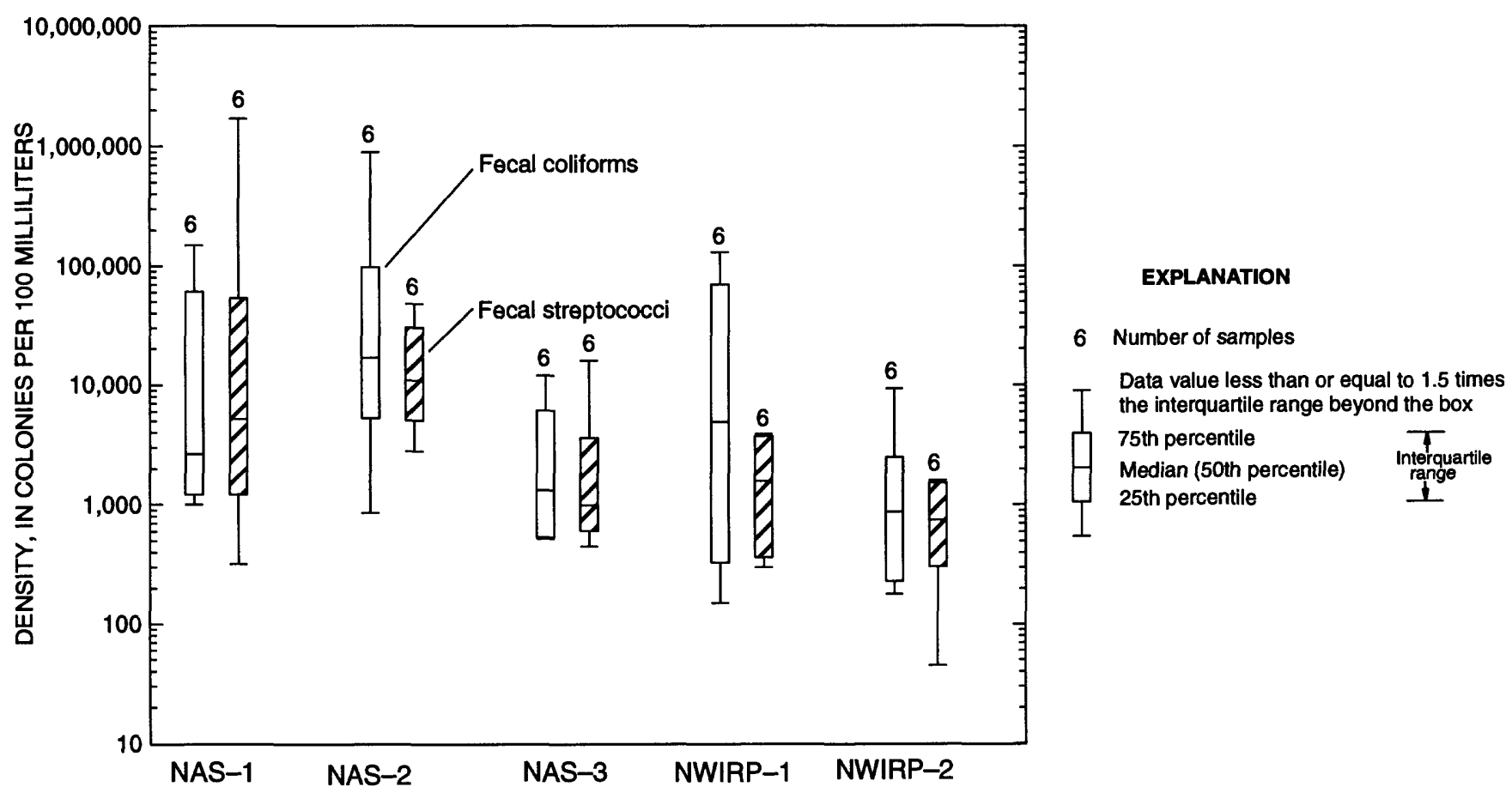

Figure 8. Range and distribution of fecal coliform and fecal streptococcus bacteria densities. 


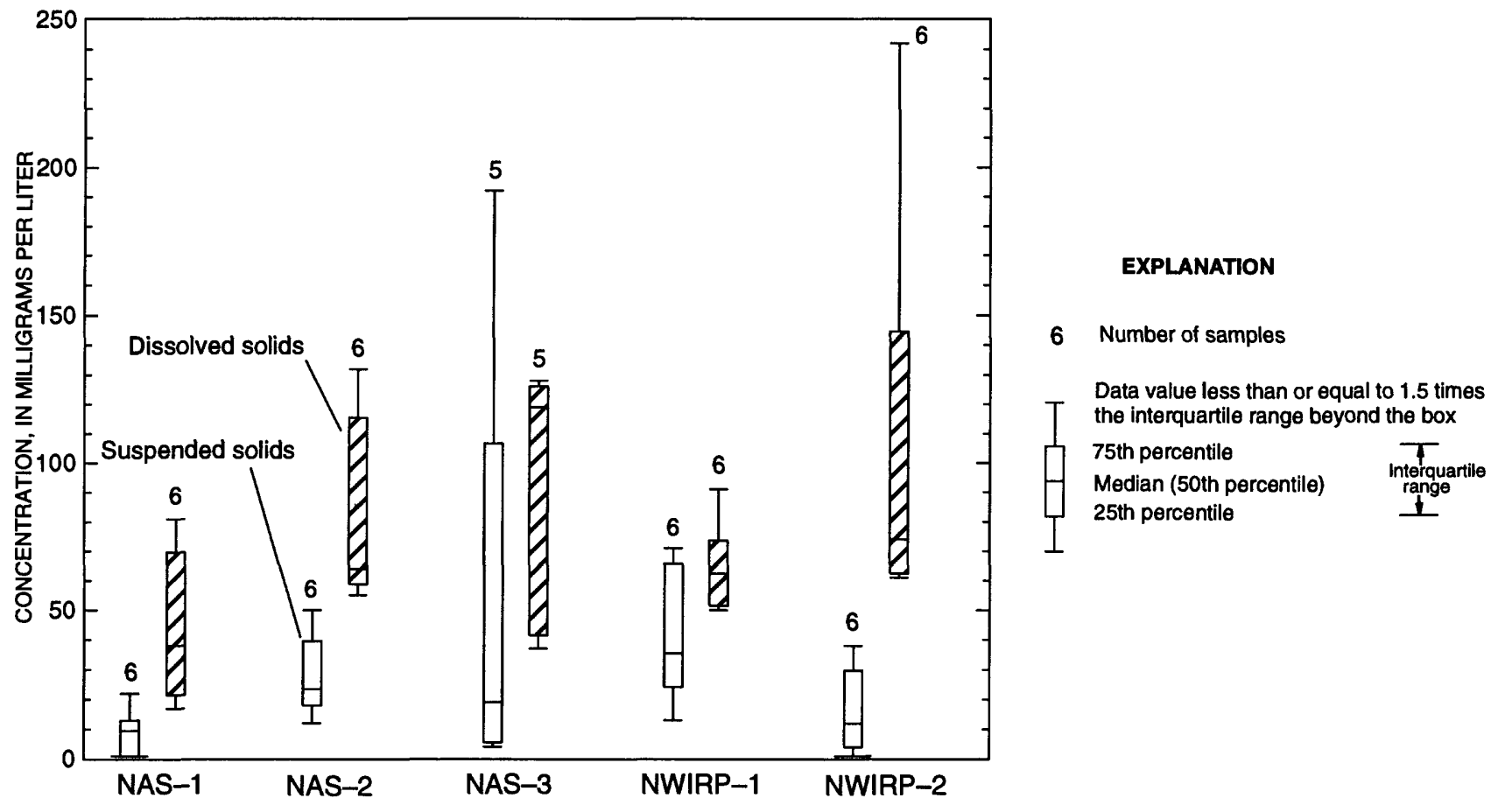

Figure 9. Range and distribution of suspended and dissolved solids concentrations.

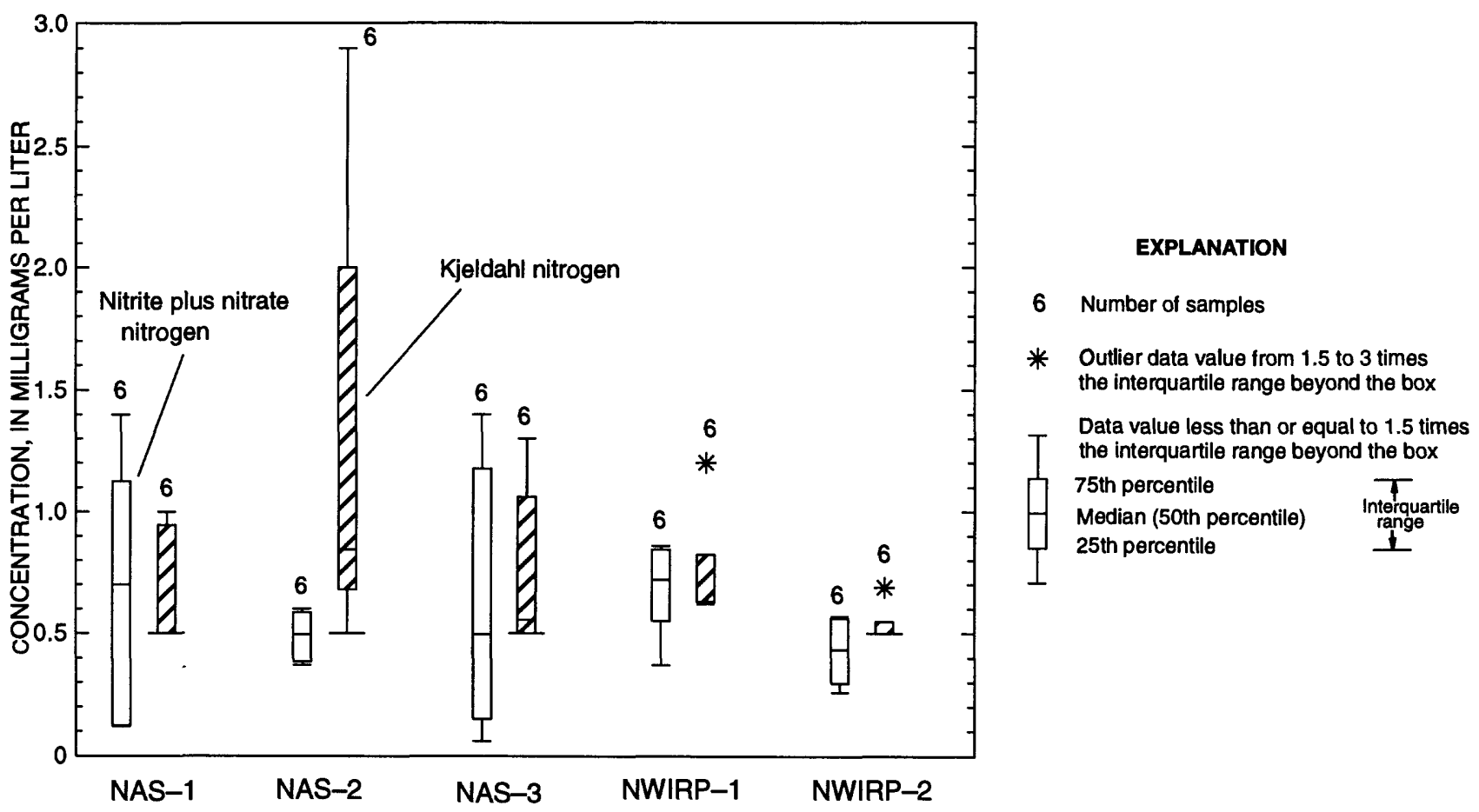

Figure 10. Range and distribution of total nitrite plus nitrate and total Kjeldahl nitrogen concentrations. 
Table 2. Characteristics of storms and samples collected at fixed sites, Naval Air Station and Naval Weapons Industrial Reserve Plant, Dallas, Texas

[in., inches; $\mathrm{ft}^{3}$, cubic feet]

\begin{tabular}{|c|c|c|c|c|c|c|c|c|c|c|c|}
\hline \multirow[b]{2}{*}{$\begin{array}{l}\text { Storm } \\
\text { date }\end{array}$} & \multirow[b]{2}{*}{$\begin{array}{l}\text { Total } \\
\text { precipi- } \\
\text { tation } \\
\text { (in.) }\end{array}$} & \multirow[b]{2}{*}{$\begin{array}{c}\text { Maximum } \\
\text { 5-minute } \\
\text { intensity } \\
\text { (in.) }\end{array}$} & \multirow[b]{2}{*}{$\begin{array}{l}\text { Antecedent } \\
\text { dry period } \\
\text { (days) }\end{array}$} & \multicolumn{4}{|c|}{ Runoff } & \multirow[b]{2}{*}{$\begin{array}{c}\text { Grab- } \\
\text { sample } \\
\text { time }\end{array}$} & \multicolumn{2}{|c|}{ Composite samples } & \multirow[b]{2}{*}{$\begin{array}{l}\text { Toxicity } \\
\text { sample } \\
\text { collected }\end{array}$} \\
\hline & & & & $\begin{array}{c}\text { Begin } \\
\text { time }\end{array}$ & $\begin{array}{l}\text { End } \\
\text { time }\end{array}$ & $\begin{array}{l}\text { Duration } \\
\text { (minutes) }\end{array}$ & $\begin{array}{c}\text { Volume } \\
\left(\mathbf{f t}^{3}\right)\end{array}$ & & $\begin{array}{l}\text { No. of } \\
\text { automatic } \\
\text { aliquots }\end{array}$ & $\begin{array}{l}\text { No. of } \\
\text { hand- } \\
\text { dipped } \\
\text { aliquots }\end{array}$ & \\
\hline \multicolumn{12}{|c|}{ NAS-1 } \\
\hline $01 / 26 / 95$ & 0.66 & 0.09 & 3 & 0940 & 1200 & 140 & 43,300 & 0943 & 16 & 7 & NO \\
\hline $03 / 12 / 95$ & .15 & .04 & 4 & 1900 & 2200 & 180 & 9,700 & 1912 & 5 & 4 & NO \\
\hline 03/25/95 & .89 & .29 & 9 & 1630 & 1915 & 165 & 61,600 & 1635 & 16 & 7 & NO \\
\hline $04 / 10 / 95$ & 1.08 & .24 & 3 & 1425 & 1700 & 155 & 71,600 & 1430 & 18 & 9 & NO \\
\hline $09 / 18 / 95$ & .39 & .07 & 5 & 1800 & 2115 & 195 & 29,700 & 1810 & 9 & 10 & YES \\
\hline $12 / 08 / 95$ & .29 & .04 & 17 & 0255 & 1130 & 515 & 23,300 & 0512 & 5 & 5 & YES \\
\hline \multicolumn{12}{|c|}{ NAS-2 } \\
\hline $11 / 02-03 / 94$ & .28 & .07 & 7 & 2349 & 0200 & 131 & 13,500 & 2355 & 6 & 5 & YES \\
\hline $11 / 09 / 94$ & .57 & .08 & 4 & 0540 & 0930 & 230 & 33,000 & 0620 & 14 & 7 & NO \\
\hline $01 / 12 / 95$ & .19 & .05 & 5 & 1727 & 2130 & 243 & 7,050 & 1740 & 3 & 5 & NO \\
\hline $05 / 31-06 / 01 / 95$ & 1.58 & .38 & 4 & 2039 & 0030 & 231 & 78,300 & 2040 & 33 & 15 & NO \\
\hline $09 / 18 / 95$ & .48 & .06 & 5 & 1750 & 2115 & 205 & 14,700 & 1800 & 7 & 8 & YES \\
\hline $03 / 27 / 96$ & .67 & .04 & 9 & 1305 & 1915 & 370 & 41,800 & 1307 & 19 & 11 & NO \\
\hline \multicolumn{12}{|c|}{ NAS-3 } \\
\hline $10 / 15 / 94$ & .12 & .07 & 6 & 0120 & 0950 & 510 & 25,900 & 0223 & 2 & 2 & NO \\
\hline $11 / 09 / 94$ & .44 & .06 & 4 & 0645 & 0930 & 165 & 135,000 & 0600 & 10 & 5 & YES \\
\hline 03/12/95 & .16 & .03 & 4 & 1900 & 2230 & 210 & 34,400 & 1900 & 4 & 4 & NO \\
\hline $03 / 25 / 95$ & .21 & .07 & 9 & 1635 & 1745 & 70 & 52,300 & 1632 & 4 & 4 & NO \\
\hline $12 / 08 / 95$ & .26 & .05 & 17 & 0300 & 1130 & 510 & 62,100 & 0521 & 4 & 4 & YES \\
\hline $03 / 27 / 96$ & .70 & .04 & 9 & 1305 & 1915 & 370 & 122,000 & 1345 & 8 & 7 & No \\
\hline \multicolumn{12}{|c|}{ NWIRP-1 } \\
\hline $11 / 09 / 94$ & .48 & .08 & 4 & 0540 & 1000 & 260 & 230,000 & 0543 & 8 & 5 & YES \\
\hline $11 / 14 / 94$ & .34 & .08 & 4 & 1120 & 1400 & 160 & 107,000 & 1130 & 4 & 5 & NO \\
\hline $03 / 25 / 95$ & 1.08 & .43 & 9 & 1640 & 2000 & 200 & 518,000 & 1642 & 16 & 9 & NO \\
\hline 04/17-18/95 & .45 & .16 & 6 & 2242 & 0115 & 153 & 198,000 & 2242 & 7 & 7 & NO \\
\hline 09/18/95 & .43 & .08 & 5 & 1810 & 2200 & 230 & 148,000 & 1815 & 5 & 6 & YES \\
\hline $03 / 27 / 96$ & .66 & .04 & 9 & 1310 & 1930 & 380 & 320,000 & 1400 & 11 & 8 & NO \\
\hline \multicolumn{12}{|c|}{ NWIRP-2 } \\
\hline $11 / 09 / 94$ & .45 & .06 & 4 & 0600 & 0900 & 180 & 187,000 & 0653 & 11 & 5 & YES \\
\hline $11 / 14 / 94$ & .35 & .09 & 4 & 1115 & 1330 & 135 & 153,000 & 1120 & 12 & 5 & NO \\
\hline $01 / 12 / 95$ & .17 & .05 & 5 & 1730 & 2100 & 210 & 39,000 & 1733 & 3 & 4 & NO \\
\hline $01 / 26 / 95$ & .22 & .07 & 3 & 0940 & 1100 & 80 & 89,100 & 0950 & 6 & 4 & NO \\
\hline $09 / 18 / 95$ & .35 & .05 & 5 & 1805 & 2115 & 190 & 79,300 & 1810 & 6 & 7 & YES \\
\hline $03 / 27 / 96$ & .58 & .04 & 9 & 1305 & 1915 & 370 & 171,000 & 1345 & 13 & 9 & NO \\
\hline
\end{tabular}


are comparable for each of the five sites. Total phosphorus concentrations range from less than the analytical detection of 0.05 to $0.35 \mathrm{mg} / \mathrm{L}$, and dissolved phosphorus concentrations range from less than the analytical detection limit of 0.05 to $0.20 \mathrm{mg} / \mathrm{L}$ at the five sites (tables 3-7). The largest total phosphorus concentration is at site NWIRP-1 (table 6), and the largest dissolved phosphorus concentration is at site NAS-2 (table 4). Less than one-half of all concentrations of total and dissolved phosphorus are greater than the analytical detection limit. The most concentrations of total and dissolved phosphorus greater than the analytical detection limit are at site NAS-2 (table 4).

The number of trace element detections in grab and composite samples collected at the five fixed sites are listed in table 8 (at end of report). Of the 21 trace elements analyzed, 14 are in concentrations greater than the analytical detection limit in either a grab or composite sample. All concentrations of antimony, beryllium, cobalt, cyanide, selenium, thallium, and vanadium are less than the analytical detection limits (tables 3-7). Aluminum, iron, manganese, and zinc are the most frequently detected trace elements. Concentrations of arsenic, cadmium, chromium, copper, lead, and nickel are more frequently detected for the last two storms because of the lower analytical detection limits used for those samples. Only one detection of mercury was measured in a grab sample collected at site NAS-1 (table 3), and one detection of silver was measured in a grab sample collected at site NWIRP-1 (table 6). A few detections of barium and molybdenum were measured in grab and composite samples collected at sites NWIRP-1 and NWIRP-2 (tables 6-7).

The total number of trace element detections in grab and composite samples collected at the five sites are shown in figure 11. The number of detections are comparable for grab and composite samples collected at each of the five sites. The trace element concentrations of the grab samples generally exceed the concentrations of the composite samples (tables 3-7). The larger trace element concentrations during the first-flush phase of runoff (characterized by the grab sample) are diluted by subsequent runoff throughout the remainder of the storm (characterized by the composite sample).

Five trace elements (arsenic, barium, cadmium, chromium, and mercury) of the 14 detected at the five sites (table 9 at end of report) have a maximum contaminant level (MCL) established by the U.S. Environmental Protection Agency (1996). Of these five trace elements, only cadmium was detected in concentrations that exceed the MCL of $5 \mu \mathrm{g} / \mathrm{L}$ (micrograms per liter) 6 and $9 \mu \mathrm{g} / \mathrm{L}$ in grab samples collected at site NAS-1 and $6 \mu \mathrm{g} / \mathrm{L}$ in a grab sample collected at site NWIRP-1 (tables 3,6).

Eleven trace elements of the 14 detected at the five sites have an effluent limit (table 10 at end of report) for the discharge of hazardous metals into inland waters established by the Texas Natural Resource Conservation Commission (1986). All concentrations of the 11 trace elements in grab and composite samples are less than the effluent limits (tables 3-7). All lead concentrations in grab samples are less than the effluent limit for the discharge of water containing other petroleum substances (table 11 at end of report) established by the Texas Natural Resource Conservation Commission (1988).

Total organic carbon concentrations at the five sites (tables 3-7) range from $2.5 \mathrm{mg} / \mathrm{L}$ at site NAS-1 to $33 \mathrm{mg} / \mathrm{L}$ at site NAS-2. Oil and grease concentrations range from less than the analytical detection limit of $1 \mathrm{mg} / \mathrm{L}$ at all sites to $11 \mathrm{mg} / \mathrm{L}$ at site NAS-1. The concentrations of phenols range from less than the analytical detection limit of $1 \mu \mathrm{g} / \mathrm{L}$ at most sites to $18 \mu \mathrm{g} / \mathrm{L}$ at site NAS-2. Concentrations of oil and grease and phenols for the six storms at site NWIRP-2 were mostly smaller than concentrations for storms at the other sites.

The number of detections of VOCs, SVOCs, and organophosphorus pesticides for the five sites are listed in table 8 . Of the 74 VOCs analyzed, 26 were detected in concentrations at or greater than the respective analytical detection limit. Dichloroethylenes, trichloroethylene, benzenes, toluene, xylenes, and naphthalene are detected most frequently. Most detections of benzenes, toluene, xylenes, and naphthalene are at site NAS-2. Most of the VOCs detected at sites NAS-1 and NAS -3 are at or near the analytical detection limit. Dichloroethylenes and trichloroethylene were detected at sites NWIRP-1 and NWIRP-2. The total number of VOCs detected in grab and composite samples for the five sites are shown in figure 12. Site NAS-2 has substantially more VOC detections than the other four sites. The number of VOC detections in composite samples at sites NAS-1, NAS-2, and NAS-3 is more than 2 times the number of detections in grab samples. The number of VOC detections in grab and composite samples are comparable at sites NWIRP-1 and NWIRP-2. Concentrations of benzenes, toluene, and xylenes in the composite samples at site NAS-2 generally exceed the concentrations in the grab samples (table 4). Concentrations of dichloroethylenes and trichloroethylene in the 


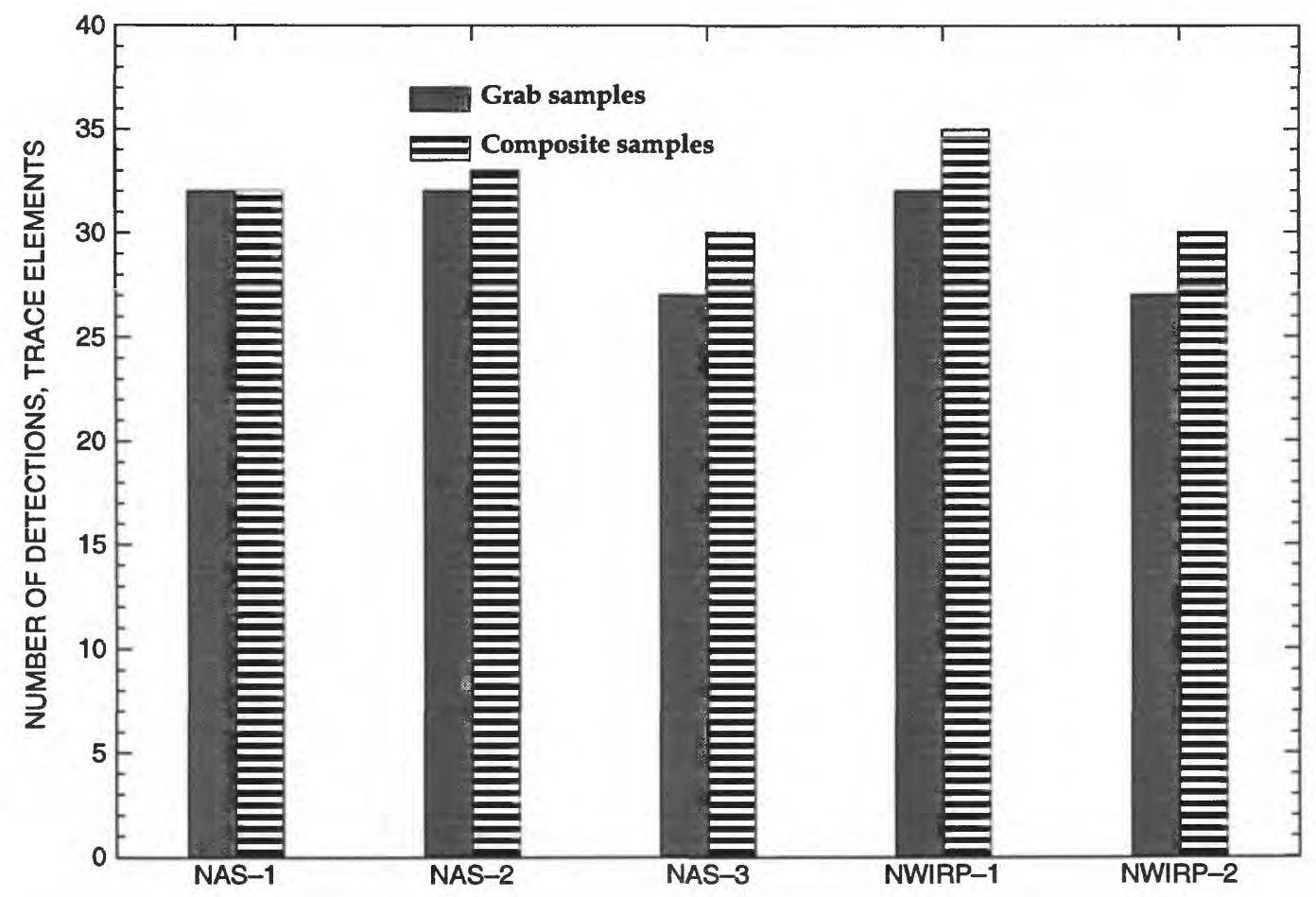

Figure 11. Number of detections for trace elements.

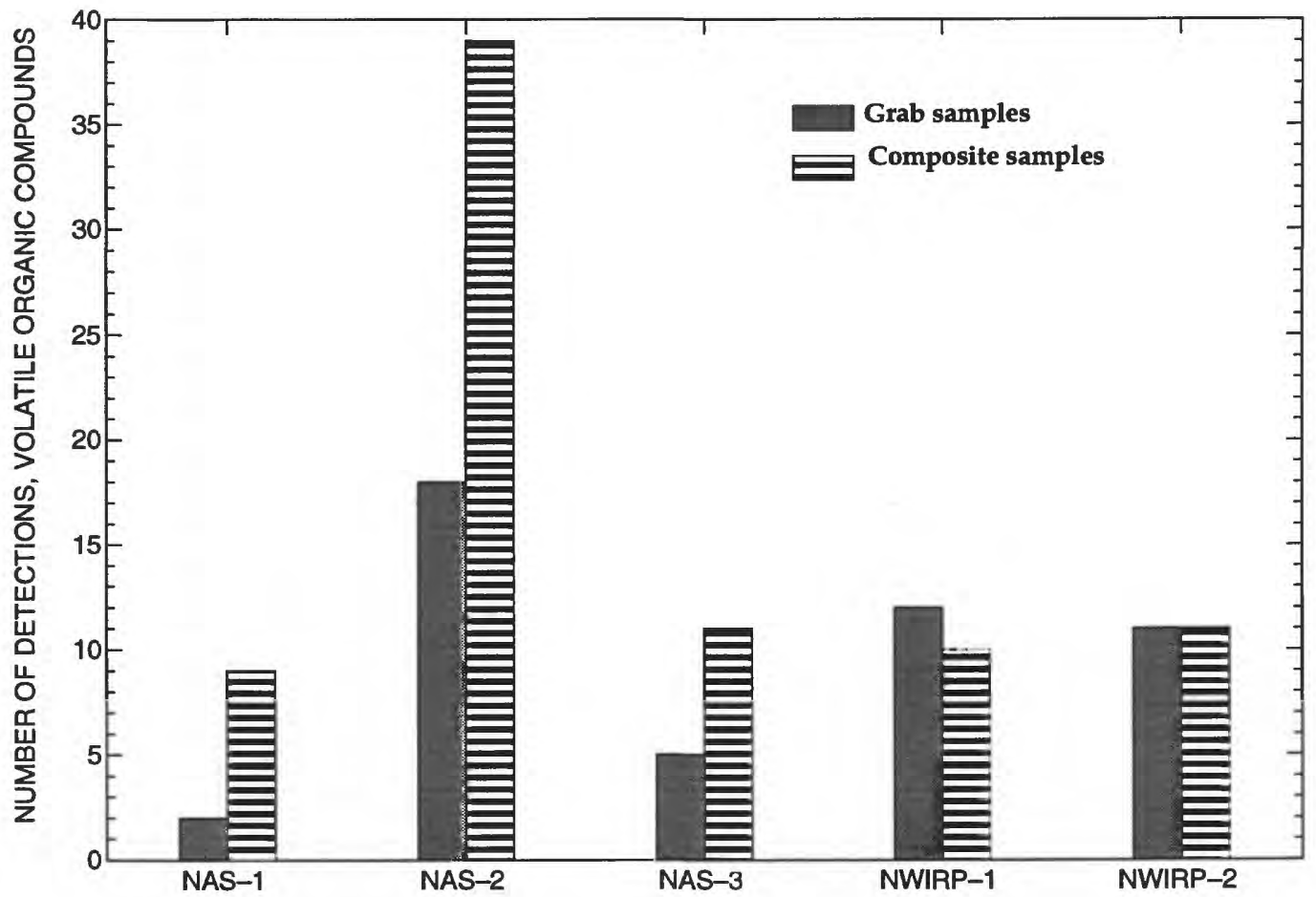

Figure 12. Number of detections for volatile organic compounds. 
grab samples at sites NWIRP-1 and NWIRP-2 generally exceed the concentrations in the composite samples (tables 6-7).

An MCL has been established for 9 VOCs of the 26 detected in a least one grab or composite sample at the five sites. Concentrations of two VOCs exceed the respective MCL (table 9)-trichloroethylene in four grab and four composite samples at site NWIRP-1 and in four grab and two composite samples at site NWIRP2; and benzene in one grab and four composite samples at site NAS-2. Although substantial concentrations (compared to the analytical detection limit) of toluene and xylenes were detected at site NAS-2, the concentrations are 1 and 2 orders of magnitude, respectively, less than the MCL. The number of detections of benzene and total BTEX (benzene, toluene, ethylbenzene, and xylene) in grab samples that exceed effluent limits for discharge of water containing other petroleum substances established by the Texas Natural Resource Conservation Commission (1988) are listed in table 11. One benzene concentration in a grab sample at site NAS-2 $(63 \mu \mathrm{g} / \mathrm{L}$, table 4$)$ exceeds the effluent limit of $50 \mu \mathrm{g} / \mathrm{L}$.

Of the 57 SVOCs analyzed in composite samples, 6 were detected in concentrations greater than the analytical detection limit (table 8). One detection of bis(2-ethylhexyl)phthalate, a common lab contaminant, is at site NAS-1 (table 3). Two detections of naphthalene, one detection of 2,4-dimethylphenol, and one detection of phenol are at site NAS-2 (table 4). Two detections of benzidine and one detection of fluoranthene are at site NAS-3 (table 5). SVOCs were not detected at sites NWIRP-1 and NWIRP-2 (tables 6-7).

None of the 27 organochlorine pesticides and polychlorinated biphenyls analyzed in composite samples at each of the five sites were detected. Of the 24 organophosphorus pesticides analyzed in composite samples, 2 were detected in concentrations greater than the analytical detection limit (table 8)-diazinon in one sample at site NAS-2 and stirophos in one sample at site NAS-2 and two samples at site NAS-3.

\section{Grab Sites}

Stormwater-quality data for grab samples collected at the four grab sites during two storms (September 18, 1995, and October 2, 1995) are listed in table 12 (at end of report). Samples also were collected at four of the five fixed sites during the September storm. Samples were not collected at fixed sites during the October storm because the runoff from 0.15 in. of precipitation was insufficient to collect composite samples. Precipitation, discharge, and runoff-volume data were not collected at the grab sites. Specific conductance ranges from 36 to $724 \mu \mathrm{S} / \mathrm{cm}, \mathrm{pH}$ ranges from 7.9 to 8.4 , and water temperature ranges from 24.0 to $26.0^{\circ} \mathrm{C}$ at the four sites.

The total number of detections of trace elements and VOCs in the four grab sites are listed in table 13 (at end of report). Concentrations of 8 of the 11 trace elements analyzed are greater than the analytical detection limit. Beryllium, selenium, and silver were not detected. Copper, lead, and zinc were detected in both samples at all sites. Cadmium, chromium, and nickel were detected in both samples at every site except site GRAB-5.

Arsenic was detected in one sample at site GRAB-1 and two samples at site GRAB-2. Mercury was detected in one sample at site GRAB-5. Only one trace element concentration exceeds its MCL at the four grab sites. A cadmium concentration of $9.0 \mu \mathrm{g} / \mathrm{L}$ at site $\mathrm{GRAB}-4$ (table 12) exceeds the MCL of $5.0 \mu \mathrm{g} / \mathrm{L}$. Trace element concentrations at the four grab sites did not exceed the effluent limits for discharge of hazardous metals into inland waters listed in table 10 or the effluent limits for discharge of water containing other petroleum substances listed in table 11.

Concentrations of 5 VOCs of the 63 analyzed in grab samples collected at the four grab sites exceed the analytical detection limits (table 13). Concentrations of 1,1,2-trichloro-1,2,2-trifluoroethane were slightly greater than the analytical detection limit in one sample each at sites GRAB-1 and GRAB-2. Methylene chloride, a common lab contaminant, was detected in one sample at each of the four sites. The remaining three VOCs were detected at site GRAB-21,1-dichloroethane and dibromochloromethane in one sample and chloroform in both samples. VOC concentrations at the four grab sites did not exceed any MCL listed in table 9 or the effluent limits for discharge of water containing other petroleum substances listed in table 11.

\section{Quality Assurance and Quality Control}

Field blank samples analyzed for major ions indicate only one sample collected at NAS-1 on May 26,1995 , with a concentration of $0.26 \mathrm{mg} / \mathrm{L}$ dissolved calcium. A field blank at site NWIRP-1 analyzed for trace elements on May 26, 1995, and associated with a sample collected on April 17, 1995, has trace element detections only of iron $(58 \mu \mathrm{g} / \mathrm{L})$ and zinc $(82 \mu \mathrm{g} / \mathrm{L})$. 
Detections of iron and zinc in the environmental sample are 3,700 and $16 \mu \mathrm{g} / \mathrm{L}$, respectively. The zinc concentration is substantially less in the environmental sample than in the field blank. VOCs were not detected in a trip blank. The field blanks analyzed for VOCs are relatively free of organic compounds. A chloroform concentration of $9.8 \mu \mathrm{g} / \mathrm{L}$ was measured in a field blank collected on February 9, 1995, at site NAS-2; however, all environmental samples have no detectable chloroform concentrations. Concentrations of several benzene compounds range from 6.9 to $69 \mu \mathrm{g} / \mathrm{L}$ in the field blank collected at site NAS-2 on February 9, 1995. Sampler lines were replaced at this site before the next sample was collected. The site was retested and VOCs were not detected. Sampler lines were replaced at NAS-2 after each storm for the remainder of the project. Site NAS-2 was the only site where VOCs were detected in the field blank. The sample lines probably were contaminated during the storm of January 12,1995 , on the basis of detections of several benzene compounds in concentrations less than the analytical detection limit in the two previous samples. SVOCs, organochlorine pesticides, and organophosphorus pesticides were not detected in field blanks.

COD in replicate samples varies from corresponding environmental samples by 11 to $28 \mathrm{mg} / \mathrm{L}$. Concentrations of major ions and nutrients in replicate samples are comparable with corresponding environmental samples. The largest variation between replicate samples and environmental samples is in trace elements, especially in grab samples. Trace element concentrations in composite sample replicates vary from environmental samples by 0 to $20 \mu \mathrm{g} / \mathrm{L}$. In the November 9, 1994, grab sample collected at site NAS-2, replicate and environmental concentrations were: for aluminium, 200 and $260 \mu \mathrm{g} / \mathrm{L}$; for iron, 330 and 680 $\mu \mathrm{g} / \mathrm{L}$; for manganese, 34 and $89 \mu \mathrm{g} / \mathrm{L}$; and zinc, 37 and $86 \mu \mathrm{g} / \mathrm{L}$. Total organic carbon in replicate samples varies from the corresponding environmental samples by 1.2 to $5.0 \mathrm{mg} / \mathrm{L}$. Organochlorine and organophosphorus pesticides were not detected in the replicate and environmental samples.

Results of analyses of the spiked VOC samples are within acceptable levels. Reference samples were submitted to field personnel for specific conductance, $\mathrm{pH}$, and alkalinity analysis and to the laboratory for nutrient analysis. Concentrations in reference samples are within an acceptable range of most probable value concentrations.

\section{Toxicity Data}

Water samples for toxicity analysis were collected during two of the six storms sampled at each of the five fixed sites. The results of the toxicity analysis are listed in table 14 (at end of report). A lowest observable effects concentration (LOEC) and no observable effects concentration (NOEC) were determined for each test. The LOEC is the lowest percent concentration of environmental water in a dilution series that affects survival and growth or reproduction of selected aquatic organisms. The NOEC is the next lower percent concentration in a dilution series below the LOEC. A dilution series is a series of tests in which the environmental water is diluted with a control water of known properties, as prescribed in U.S. Environmental Protection Agency (USEPA) Method 1000.0 for fathead minnows and USEPA Method 1002.0 for water fleas (Weber and others, 1989). A Fisher's Exact Test (Zar, 1984) was used to test for a significant difference in observable effects between the control and any of the test concentrations.

No significant differences were indicated for the fathead minnow or water flea tests in the first sample at site NAS-1 (table 14). A significant difference between the control and the 13-, 25-, 50-, and 100-percent test concentrations was indicated for the water flea reproduction test for the second sample.

No significant differences were indicated for the fathead minnow or water flea tests in the first sample at site NAS-2 (table 14). A significant difference between the fathead minnow control and the 50- and 100 -percent test concentrations for growth was indicated for the second sample. Also in the second sample, a significant difference was indicated in water flea reproduction between the control and the 25-, 50-, and 100-percent test concentrations and in water flea survival between the control and the 50- and 100-percent test concentrations.

No significant differences were indicated for the fathead minnow or water flea tests in the first sample at site NAS-3. A significant difference in water flea reproduction between the control and the 13-, 25-, 50-, and 100 -percent test concentrations was indicated in the second sample.

One significant difference in the fathead minnow growth between the control and the 100-percent test concentration in the second sample was indicated at site NWIRP-1. One significant difference in the water flea reproduction between the control and the 50-percent 
test concentration was indicated in the first sample at site NWIRP-2 but was not supported by a significant difference result at the 100-percent test concentration.

\section{Event-Mean Concentrations of Selected Constituents}

Median EMCs of 12 selected constituents were computed for the five fixed sites and compared with the EMCs computed from the Dallas-Fort Worth (DFW) area National Pollutant Discharge Elimination System (NPDES) data (Stanley Baldys III, U.S. Geological Survey, written commun., 1993) and the Nationwide Urban Runoff Program (NURP) data (U.S. Environmental Protection Agency, 1983). The DFW NPDES and NURP data are grouped by major land use. The median EMCs of each selected constituent for the 30 samples at the NAS and NWIRP, each land use for the DFW NPDES data, and each land use for the NURP data are listed in table 15 (at end of report).

The median EMCs of COD, BOD, and suspended solids for the NAS and NWIRP are substantially smaller than median EMCs for the four DFW NPDES land uses and the two NURP land uses. The dissolved solids median EMC for the NAS and NWIRP is comparable to the median EMCs for the DFW NDPES residential and industrial land uses. Dissolved solids concentrations were not measured during the NURP study. The median EMC of total nitrite plus nitrate nitrogen for the NAS and NWIRP is comparable to the EMCs for the DFW NPDES residential and commercial land uses. The median EMC of total Kjeldahl nitrogen for the NAS and NWIRP is comparable to the EMCs for the DFW NPDES commercial and industrial land uses. Median EMCs of total phosphorus and dissolved phosphorus for the NAS and NWIRP are substantially smaller than the median EMCs for the DFW NPDES and NURP data. The median EMCs of selected trace elements (cadmium, copper, lead, and zinc) for the NAS and NWIRP are comparable to the median EMCs for DFW NPDES residential and highway land uses. The median EMC of cadmium for the NAS and NWIRP also is comparable to the median EMCs for DFW NPDES commercial and industrial land uses, and the median EMC of copper for the NAS and NWIRP also is comparable to the median EMC for DFW NPDES commercial land use.

\section{Computation of Storm Loadings for Selected Constituents}

Storm loadings, in pounds, can be computed for each fixed site from the storm composite concentration of any constituent listed in tables 3-7 by multiplying the runoff volume, in cubic feet (table 2), by the constituent storm composite concentration, in milligrams per liter (or micrograms per liter), by $6.24 \times 10^{-5}$ (or $6.24 \times 10^{-8}$ ), units conversion factors. The storm loading can be divided by the drainage area to compute the constituent yield per unit area.

\section{SUMMARY}

The characterization of stormwater runoff from the NAS and the NWIRP is necessary to determine if runoff from the facilities is contributing to off-site contamination of surface waters. A network of five fixed sites and four grab sites was established to sample stormwater runoff from a substantial part of the drainage area of each facility. The fixed sites were instrumented to measure and store precipitation, stage, discharge, and runoff-volume data and to collect flowweighted composite samples during a storm.

Grab and composite samples were collected for six storms at each of the five fixed sites from October 1994 to March 1996. Grab samples were analyzed for about 100 properties and constituents including specific conductance, $\mathrm{pH}$, water temperature, bacteria (fecal coliform and fecal streptococcus), trace elements, oil and grease, total phenols, and VOCs. Composite samples were analyzed for about 220 properties and constituents including specific conductance, $\mathrm{pH}, \mathrm{COD}$, BOD, major ions, suspended and dissolved solids, nutrients, trace elements, total organic carbon, VOCs, SVOCs, organochlorine pesticides, chlorinated biphenyls, and organophosphorus pesticides. Cadmium was detected in concentrations that exceed the MCL established by the USEPA in two grab samples collected at site NAS-1 and in one grab sample collected at site NWIRP-1. Trichloroethylene concentrations in four grab and four composite samples collected at site NWIRP-1 and in four grab and two composite samples collected at site NWIRP-2 exceed the MCL. Benzene concentrations in one grab and four composite samples collected at site NAS -2 exceed the MCL. The benzene concentration in one grab sample collected at site NAS-2 exceeds the effluent limit for discharge of water 
containing other petroleum substances established by the TNRCC.

Grab samples were collected for two storms (September 18, 1995, and October 2, 1995) at each of the four grab sites and analyzed for about 80 constituents including specific conductance, $\mathrm{pH}$, temperature, trace elements, and VOCs. One cadmium concentration at site GRAB-4 exceeds the MCL. Trace element concentrations at the four grab sites did not exceed effluent limits established by the TNRCC. VOC concentrations did not exceed MCLs or effluent limits.

Composite samples collected at the fixed sites during two of the six storms were analyzed for toxicity to aquatic life using the 7-day fathead minnow growth and survival tests and the 7-day water flea reproduction and survival tests. Fathead minnow growth tests indicate significant toxicity in one sample each collected at sites NAS-2 and NWIRP-1. Fathead minnow survival tests did not indicate significant toxicity in any samples. Water flea reproduction tests indicate significant toxicity in one sample each collected at sites NAS-1, NAS-2, and NAS-3. Water flea survival tests indicate significant toxicity in one sample collected at site NAS-2.

Median EMCs computed for 12 selected constituents in samples from the NAS and NWIRP fixed sites were compared to the median EMCs for residential, commercial, industrial, and highway land use sites from the DFW NPDES data and for residential and commercial land use sites from the NURP data. The NAS and NWIRP median EMCs for COD, BOD, suspended solids, total phosphorus, and dissolved phosphorus are substantially smaller than the DFW NPDES and NURP median EMCs. The NAS and NWIRP median EMCs for dissolved solids, total nitrite plus nitrate nitrogen, total Kjeldahl nitrogen, cadmium, copper, lead, and zinc are comparable to the DFW NDPES median EMCs for selected land uses.

Storm loadings and yields for each fixed site can be computed from the composite concentration of any constituent, the runoff volume, and the contributing drainage area.

\section{REFERENCES CITED}

Texas Natural Resource Conservation Commission, 1986, Quality levels-Inland waters: Austin, Tex., Texas Administrative Code, Title 30, chap. 319:319.22. 1988, Discharge of water contaminated by other petroleum substances: Austin, Tex., Texas Administrative Code, Title 30, chap. 321:321.134.

U.S. Department of Agriculture, Soil Conservation Service, 1980, Soil survey of Dallas County, Texas: 153 p.

U.S. Department of Commerce, National Oceanic and Atmospheric Administration, 1990, Climatological data, annual summary, Texas, 1990: Asheville, N.C., v. 95, no. 13,77 p.

U.S. Environmental Protection Agency, 1983, Results of the Nationwide Urban Runoff Program-Executive summary: U.S. Environmental Protection Agency Water Planning Division, National Technical Information Service PB84-185545, 24 p.

1996, Maximum contaminant levels (part 141, natural primary drinking water regulations): Washington, D.C., U.S. Code of Federal Regulations, Title 40, parts 136-149, p. 288-429.

Weber, C.I., and others, 1989, Short-term methods for estimating the chronic toxicity of effluents and receiving waters to freshwater organisms ( $2 \mathrm{~d}$ ed.): Cincinnati, Ohio, U.S. Environmental Protection Agency, Environmental Monitoring Systems Laboratory, EPA/600/4-89/001.

Zar, J.H., 1984, Biostatistical analysis (2d ed.): Englewood Cliffs, N.J., Prentice Hall, Inc., 718 p. 


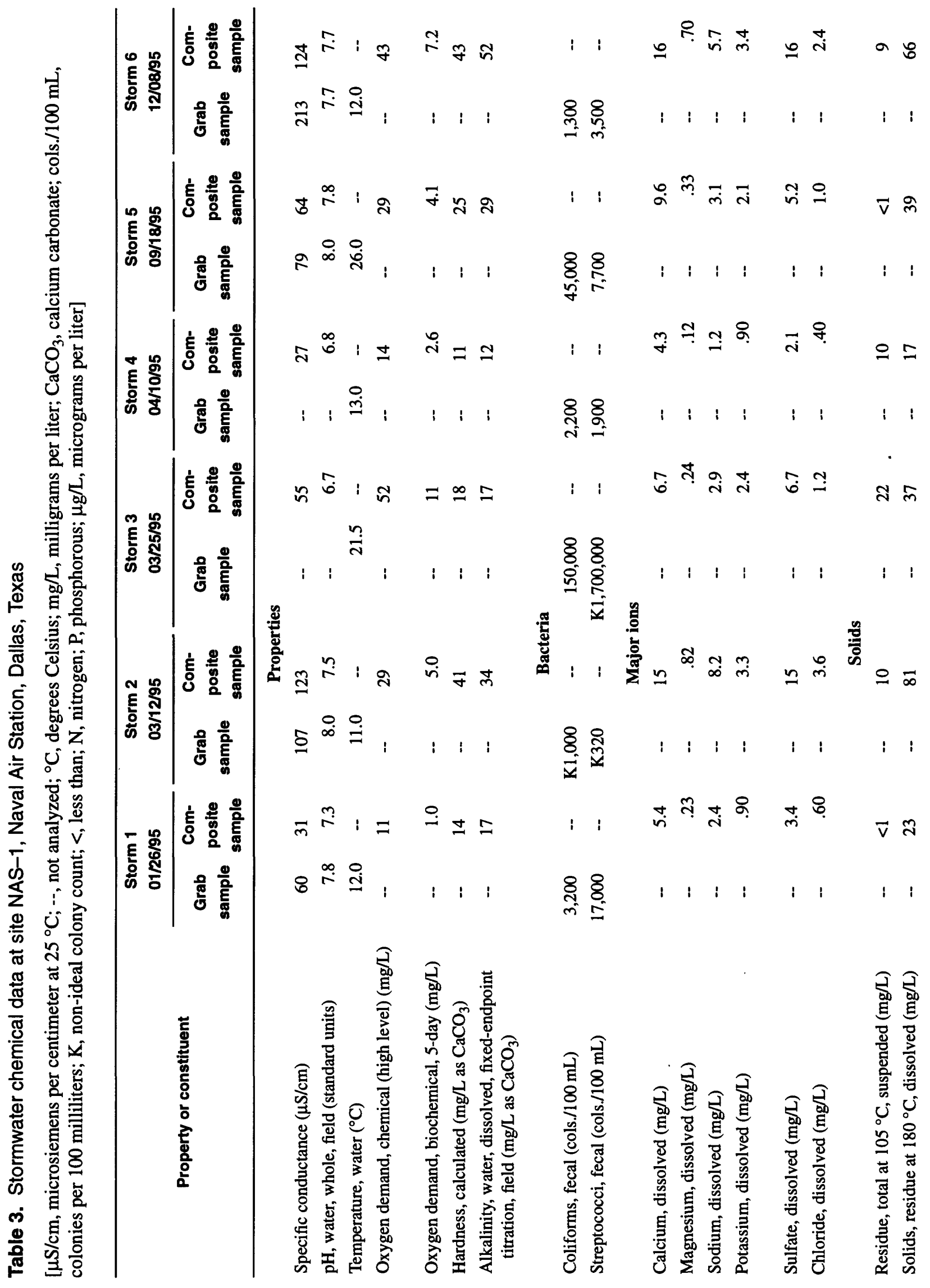




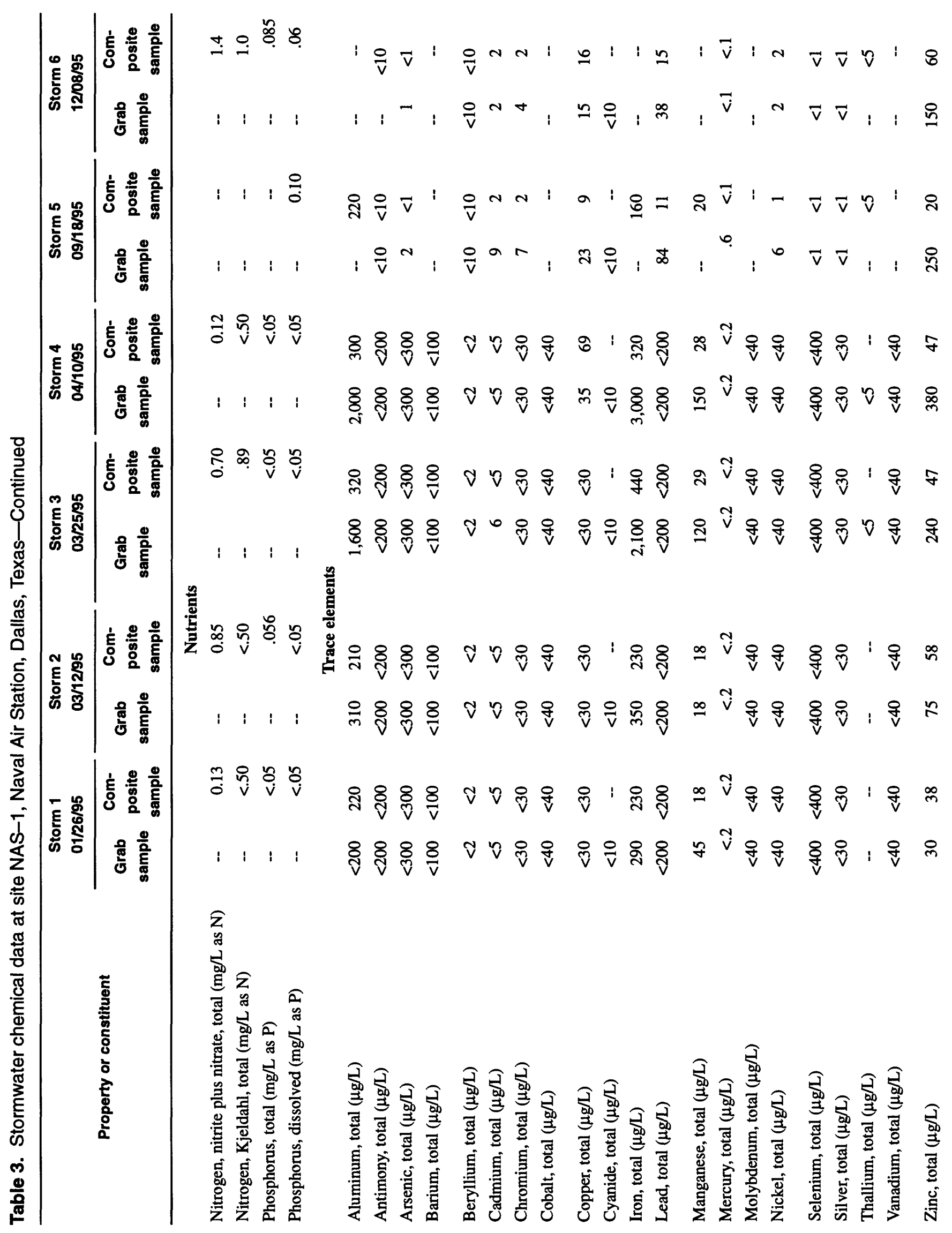




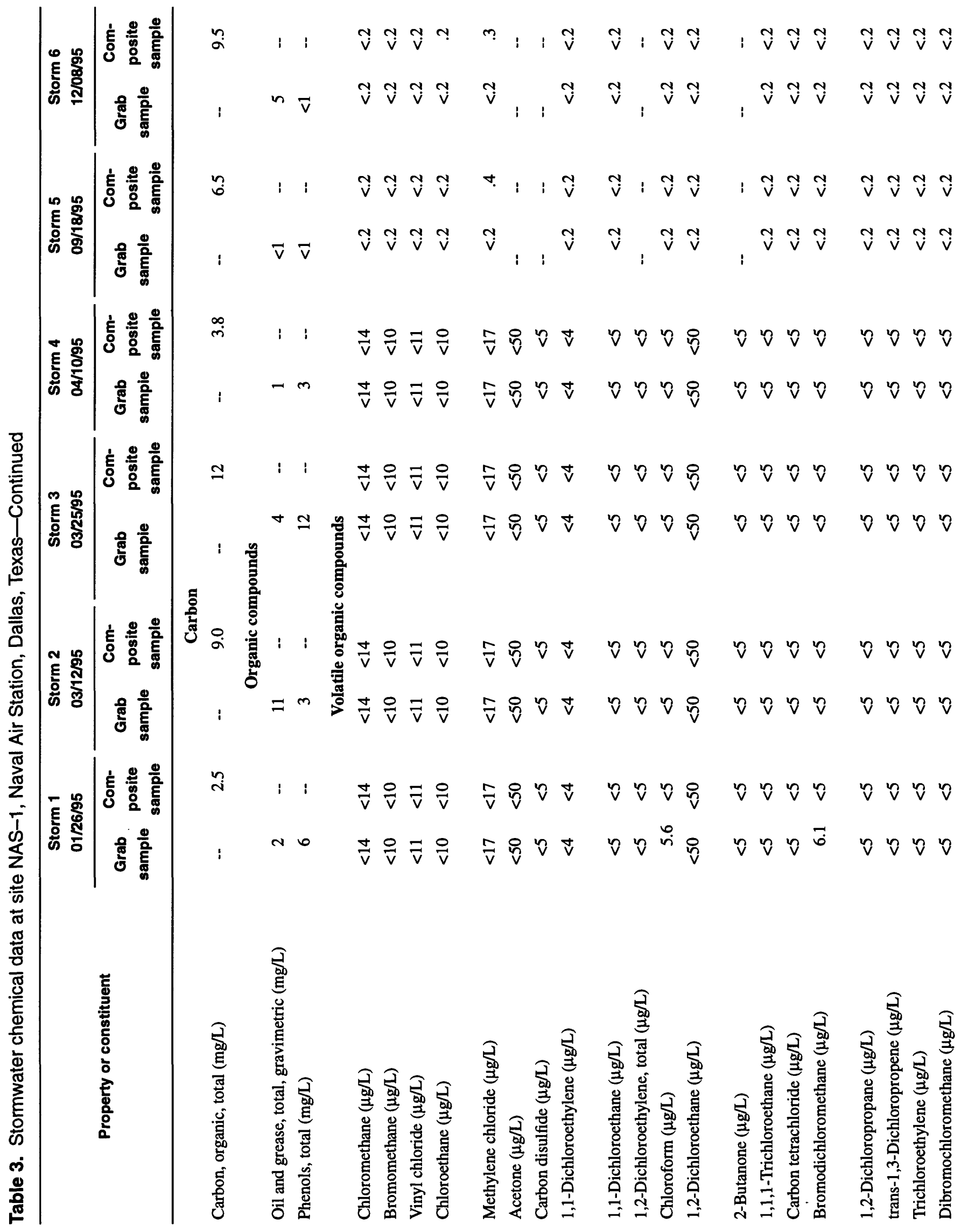




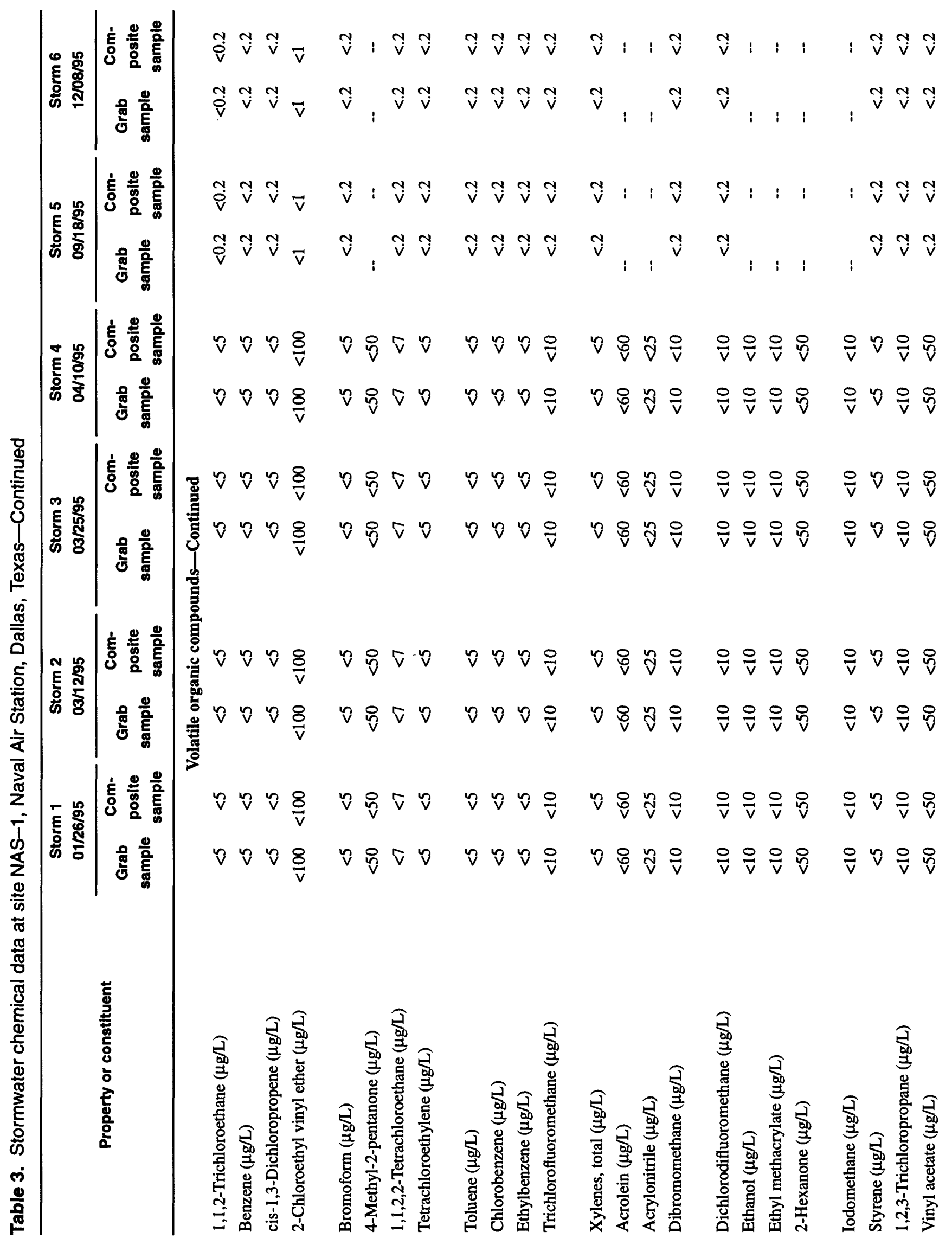




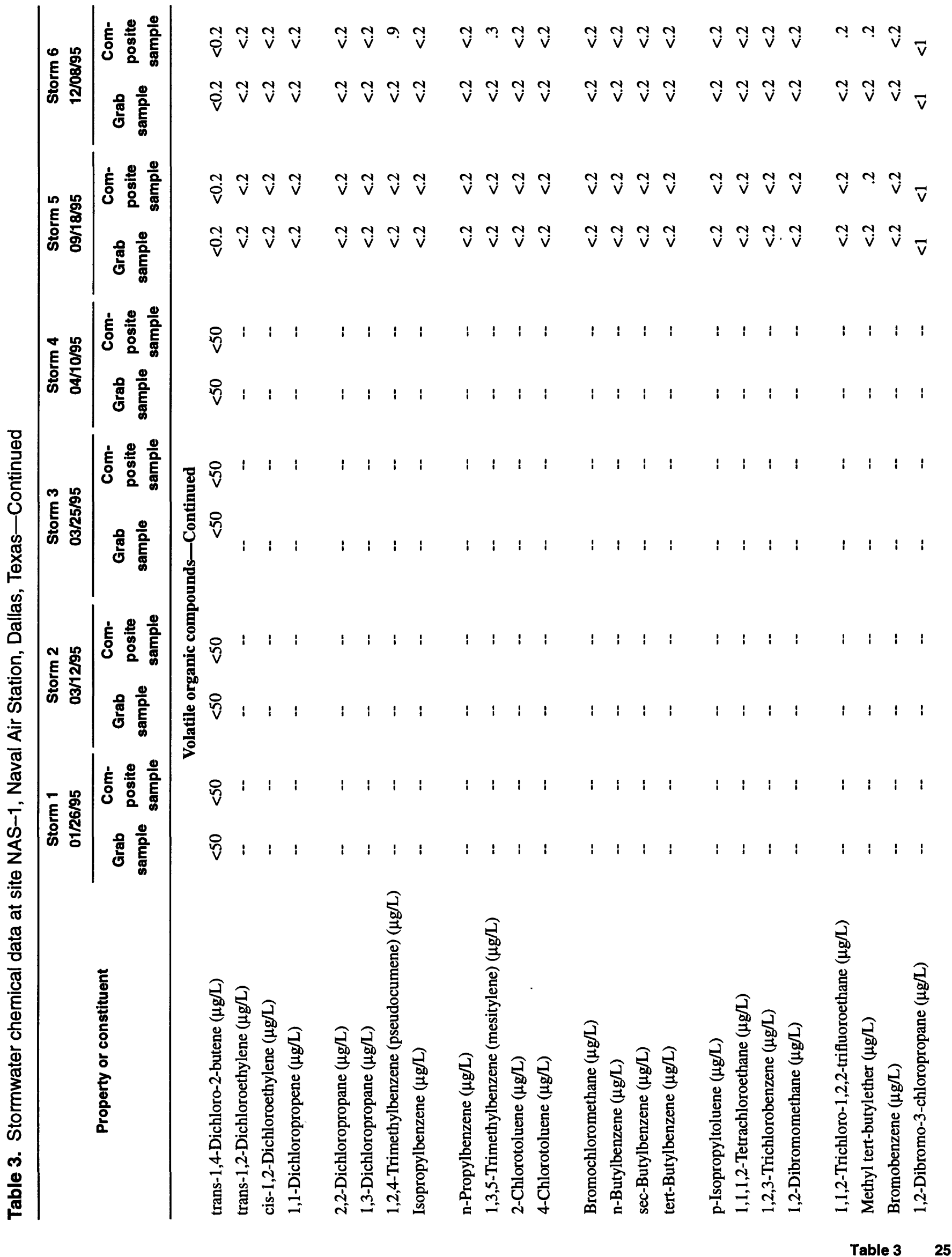




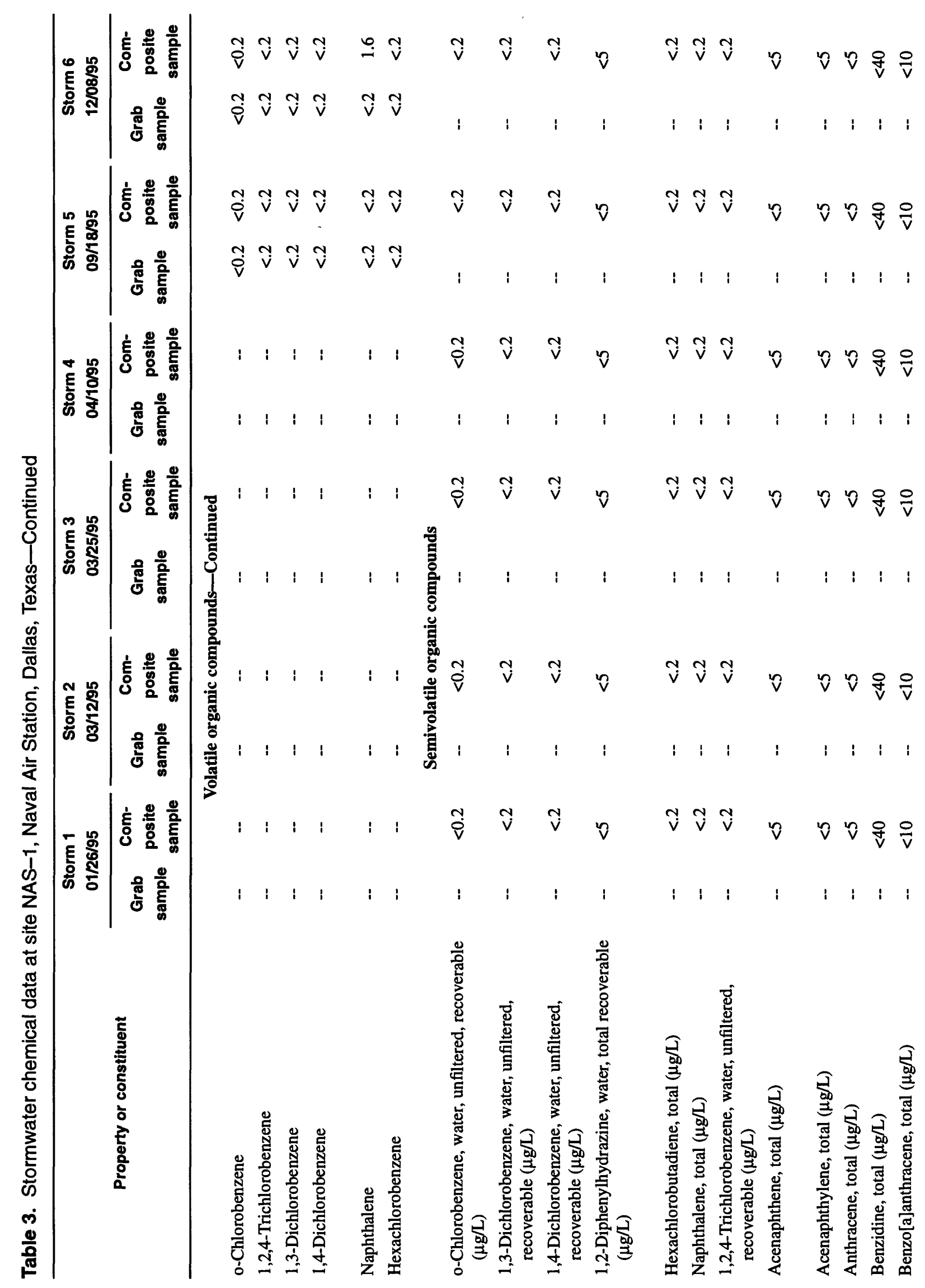




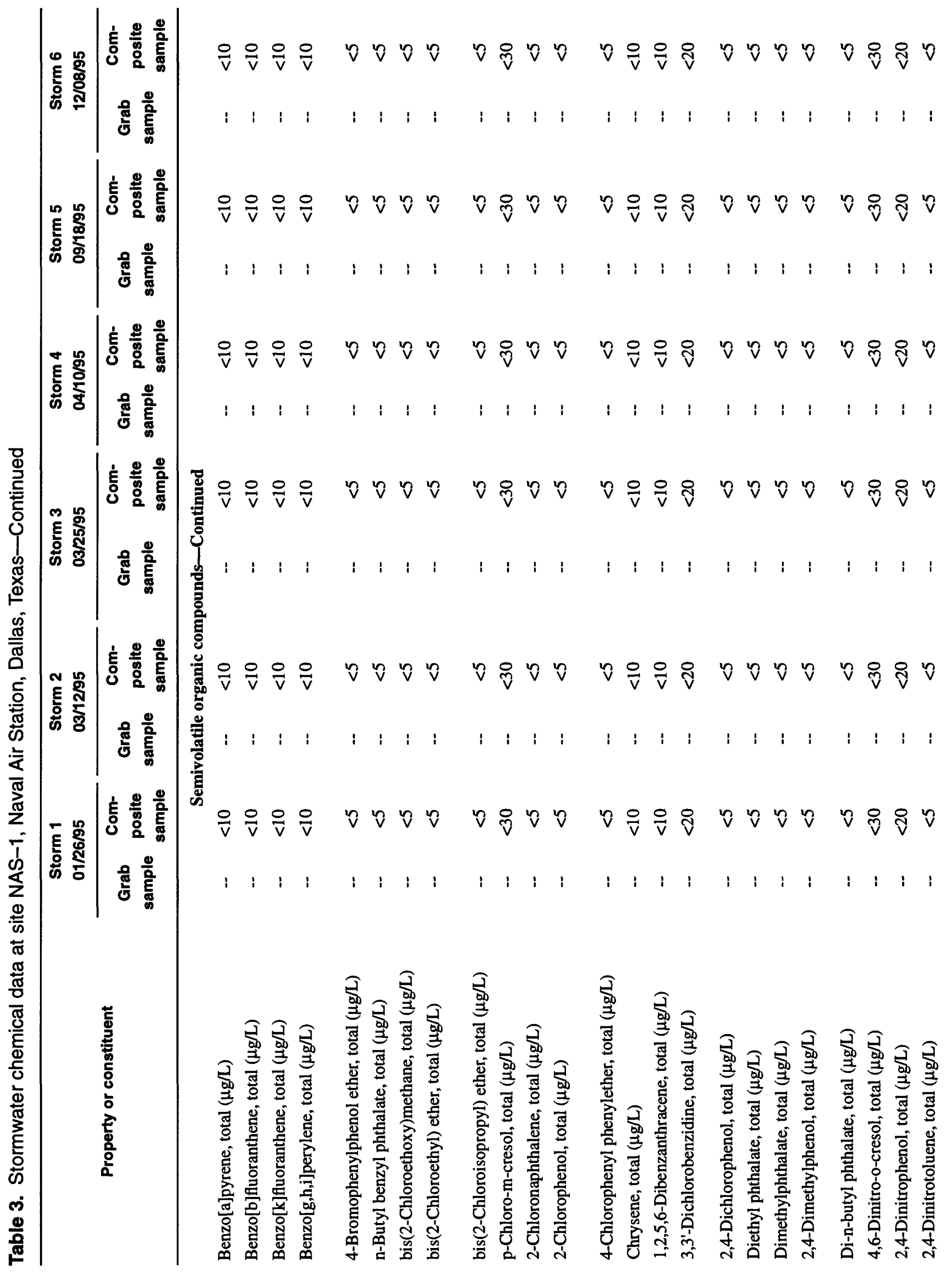




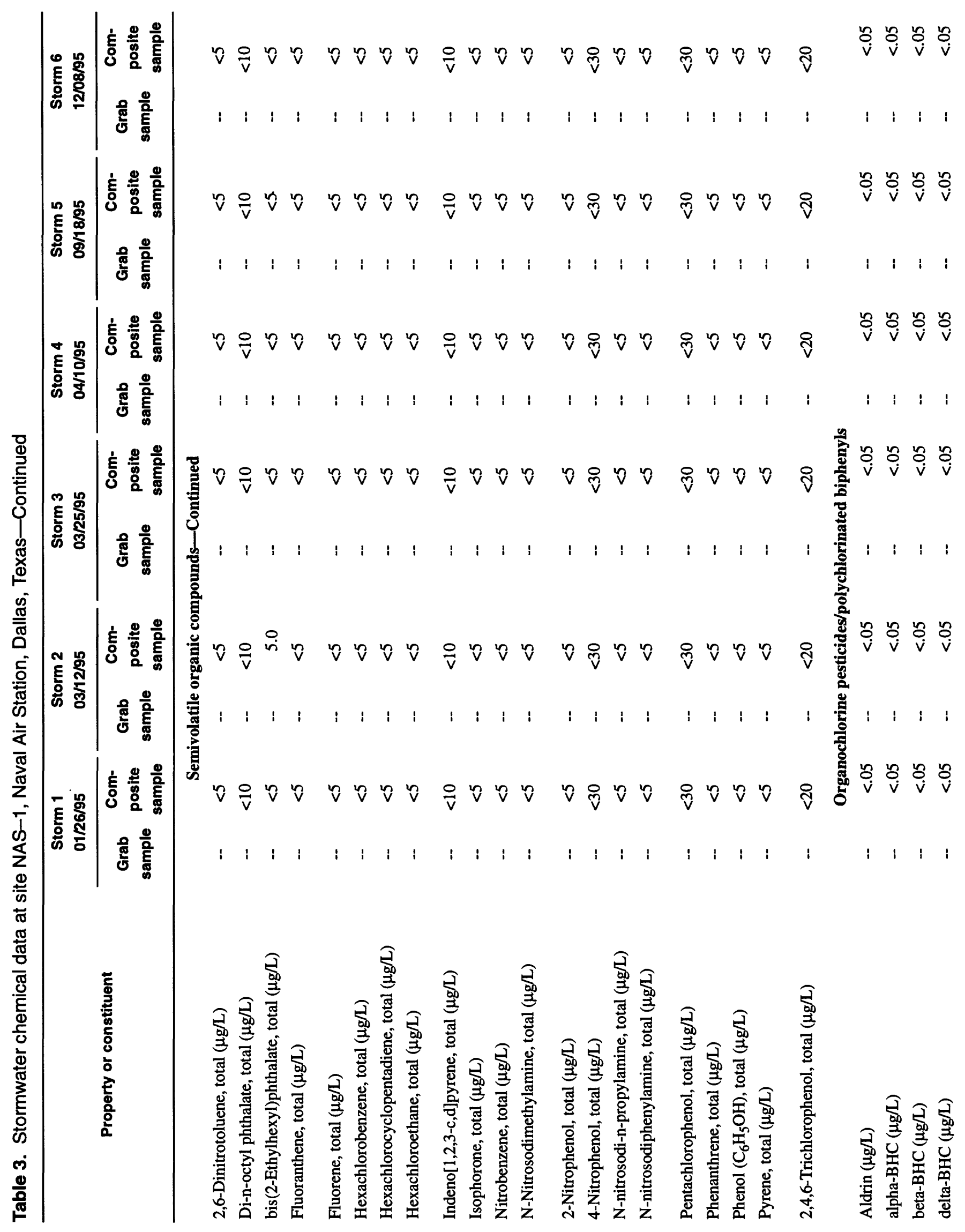




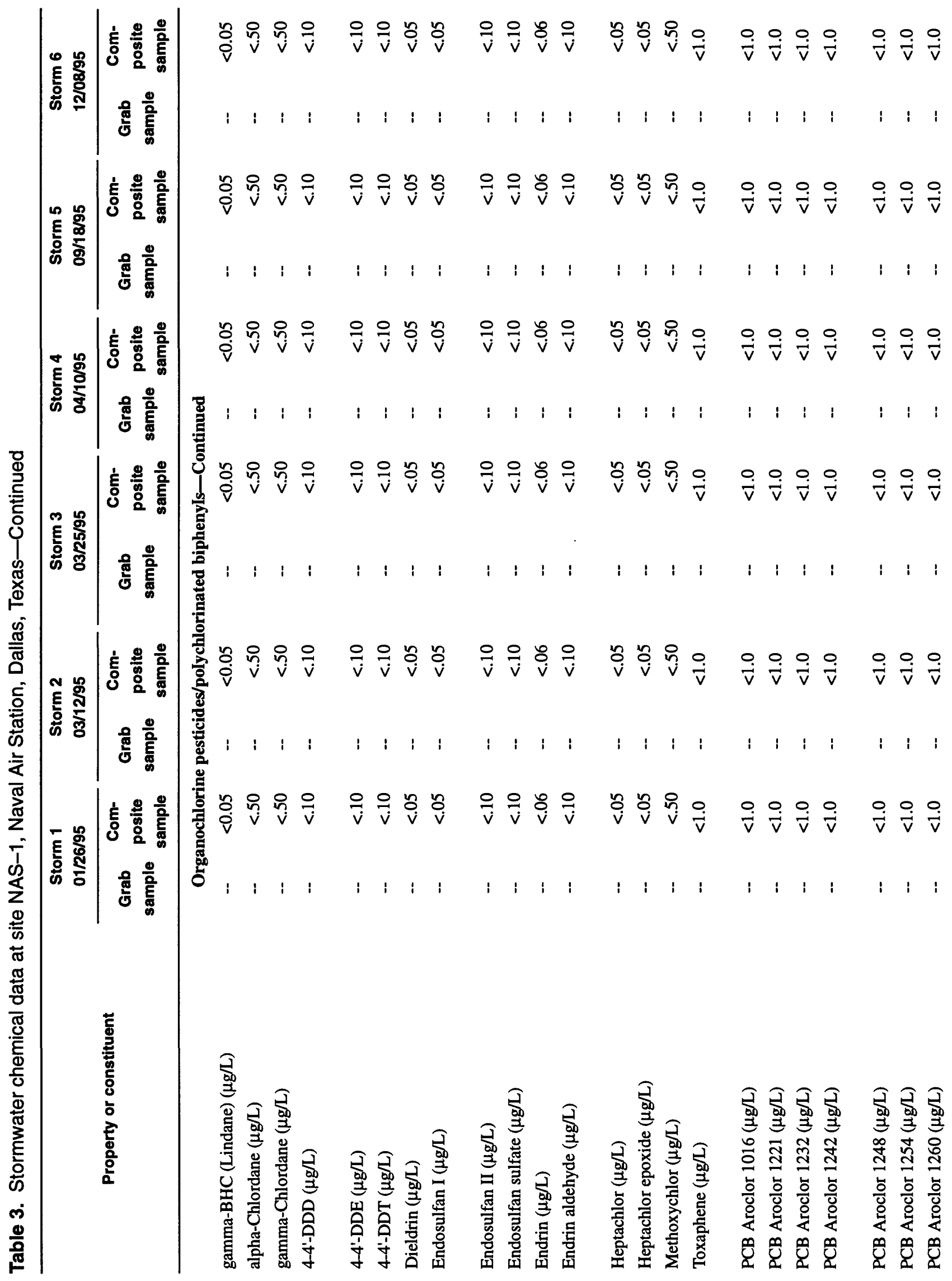




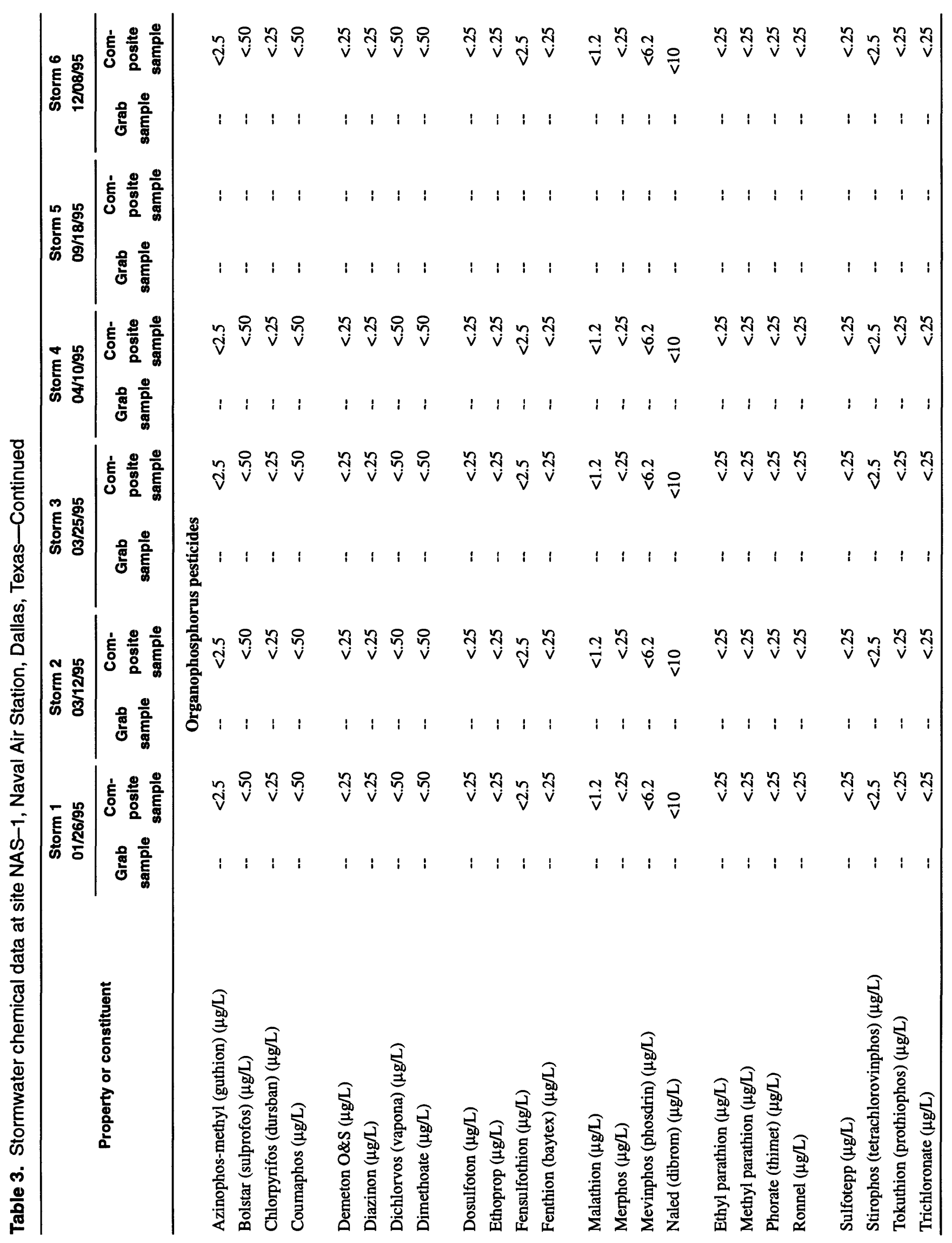




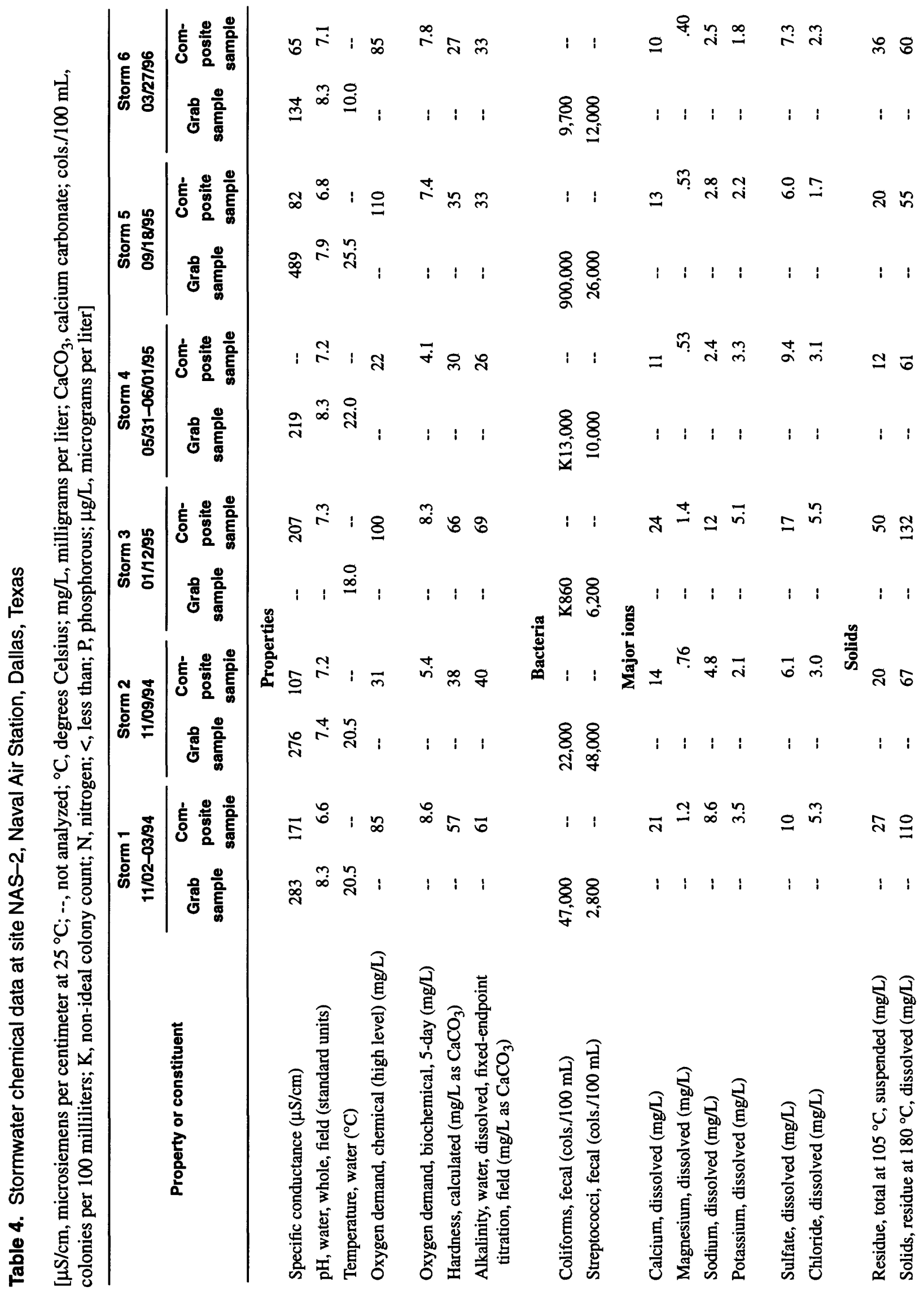




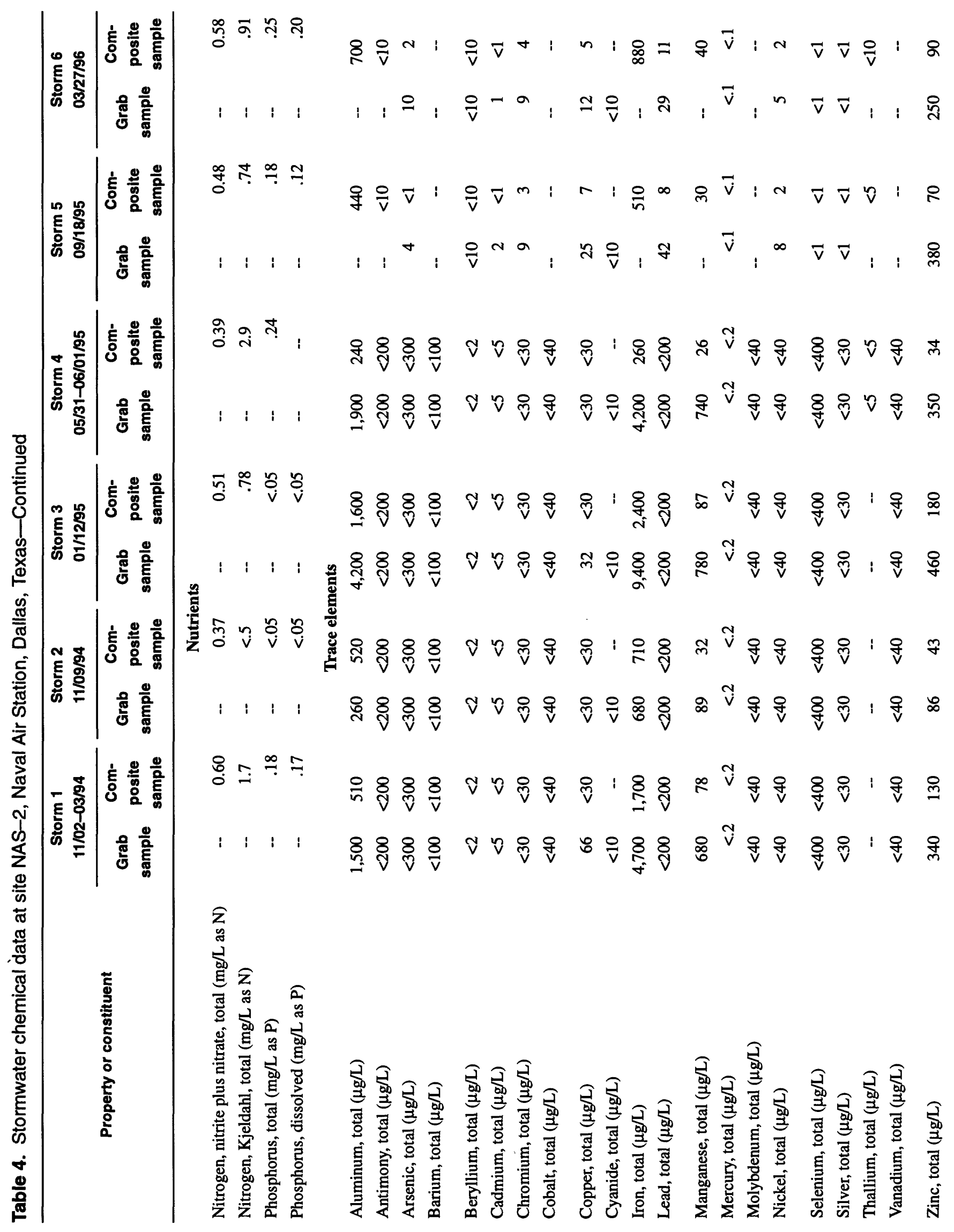




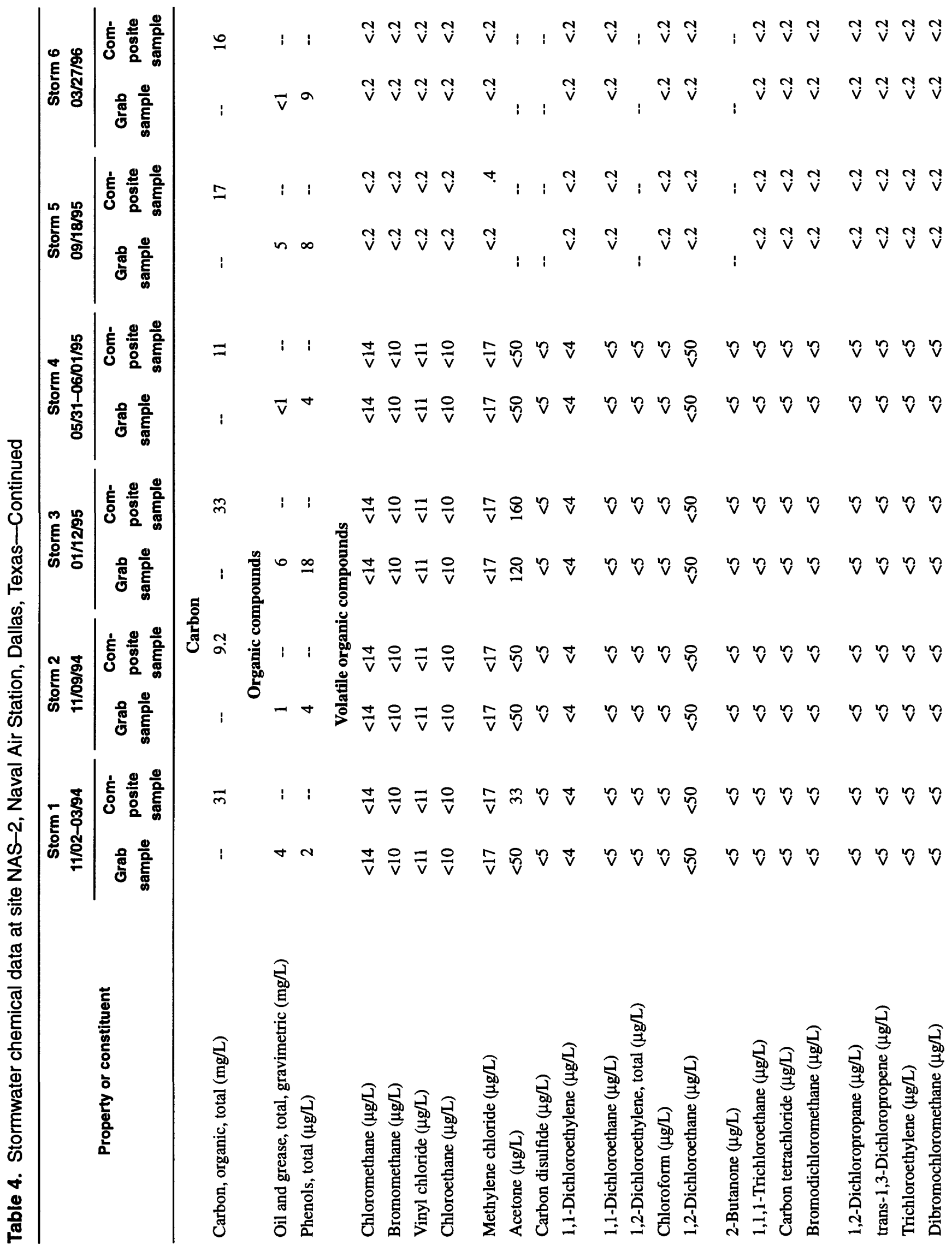




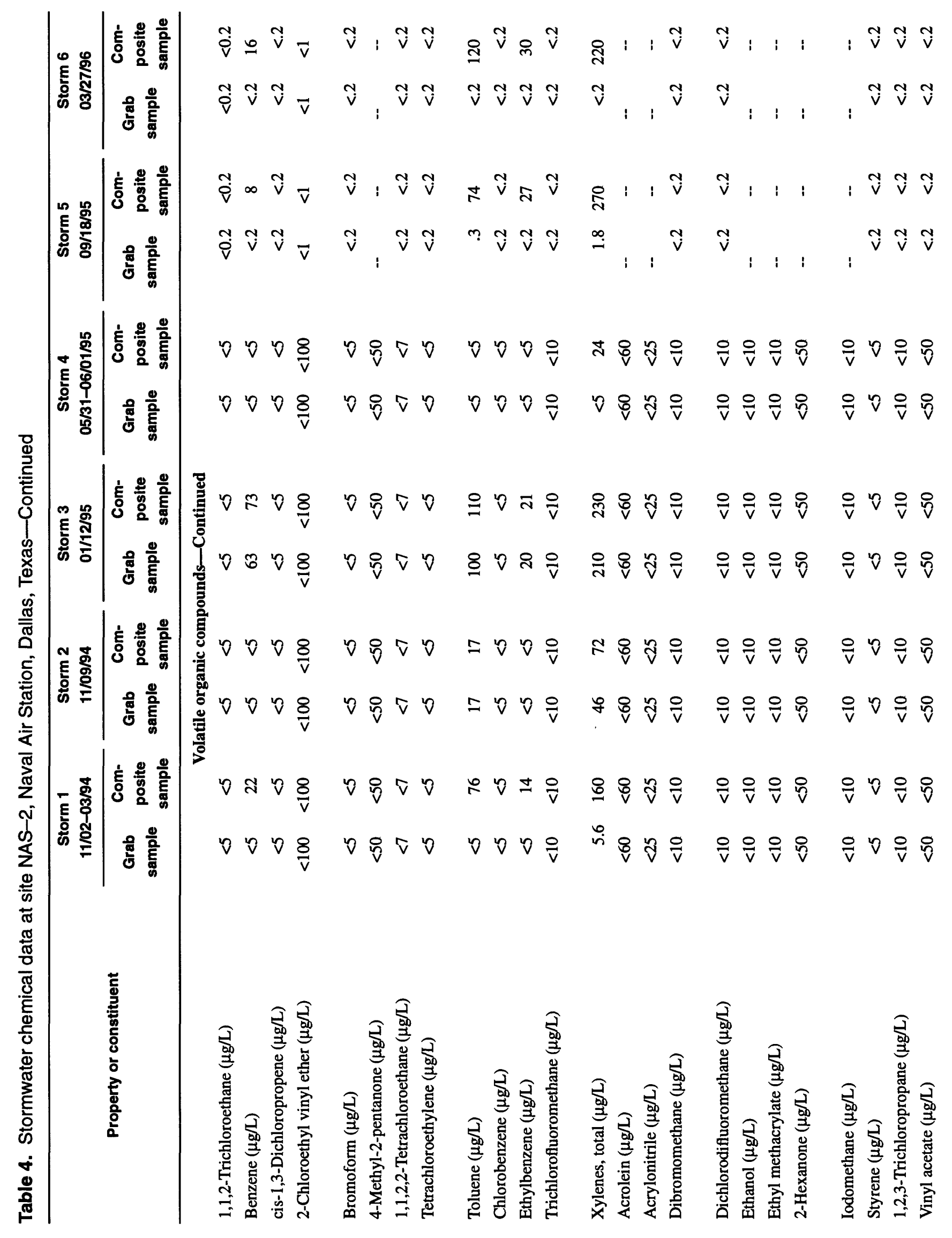




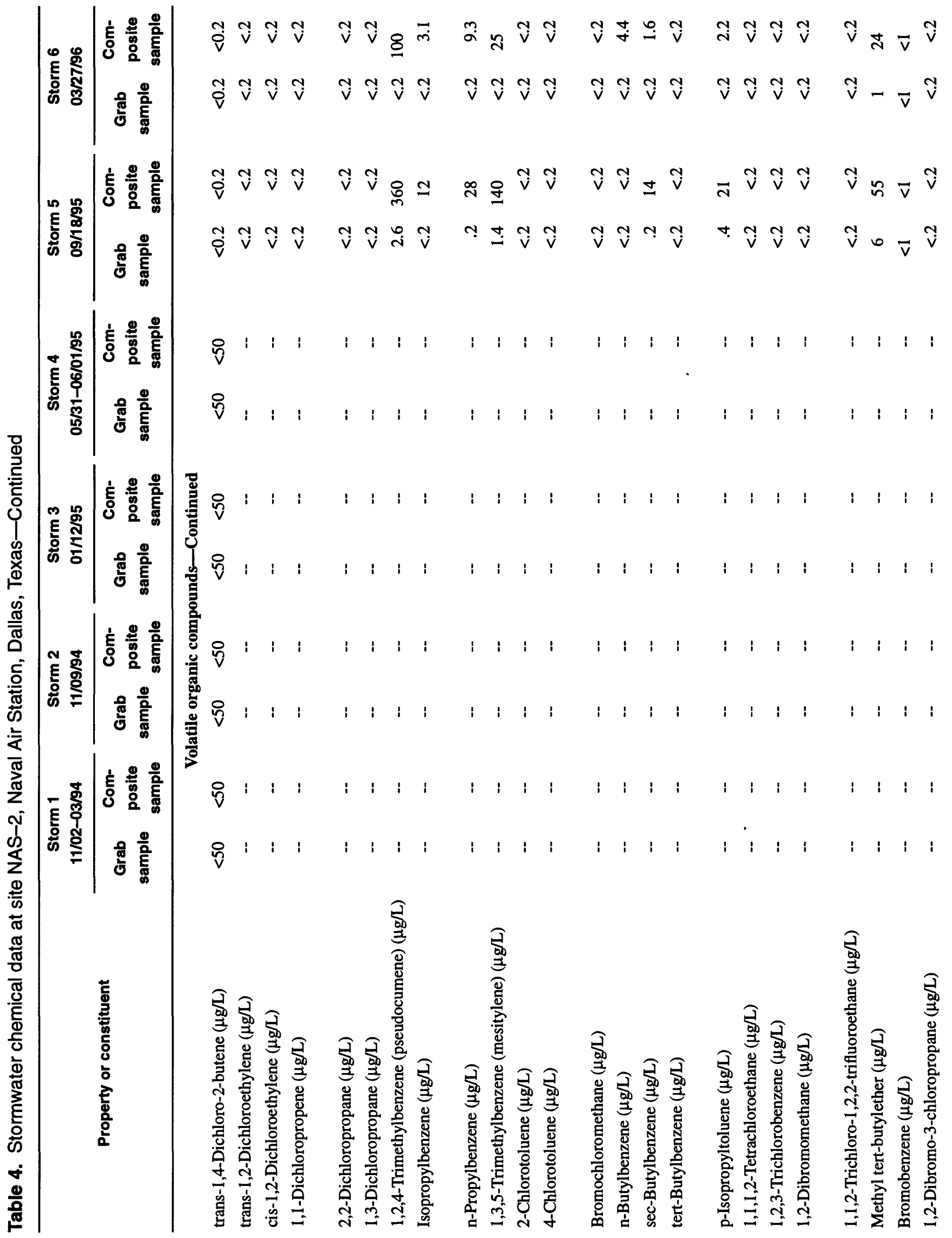




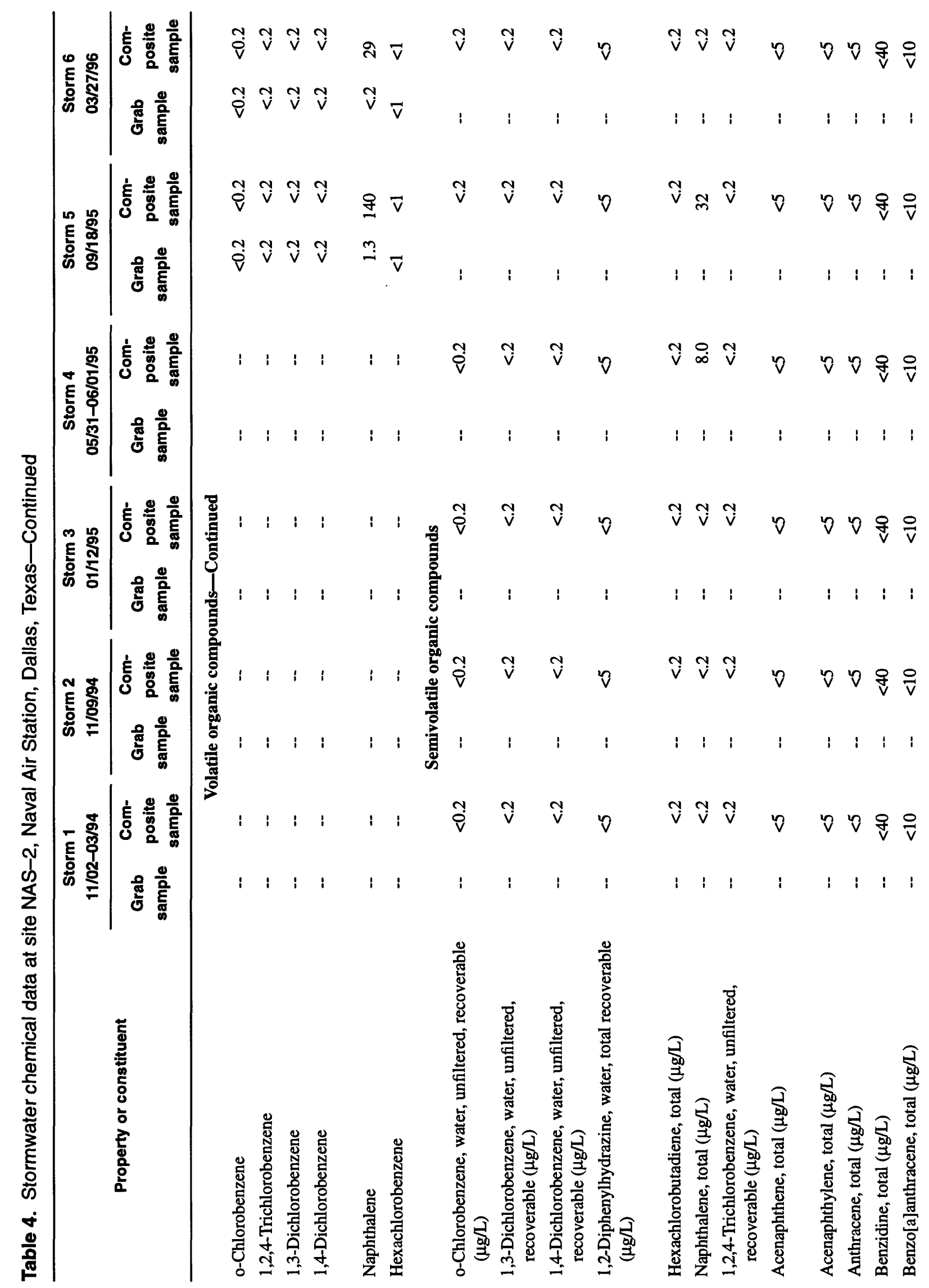




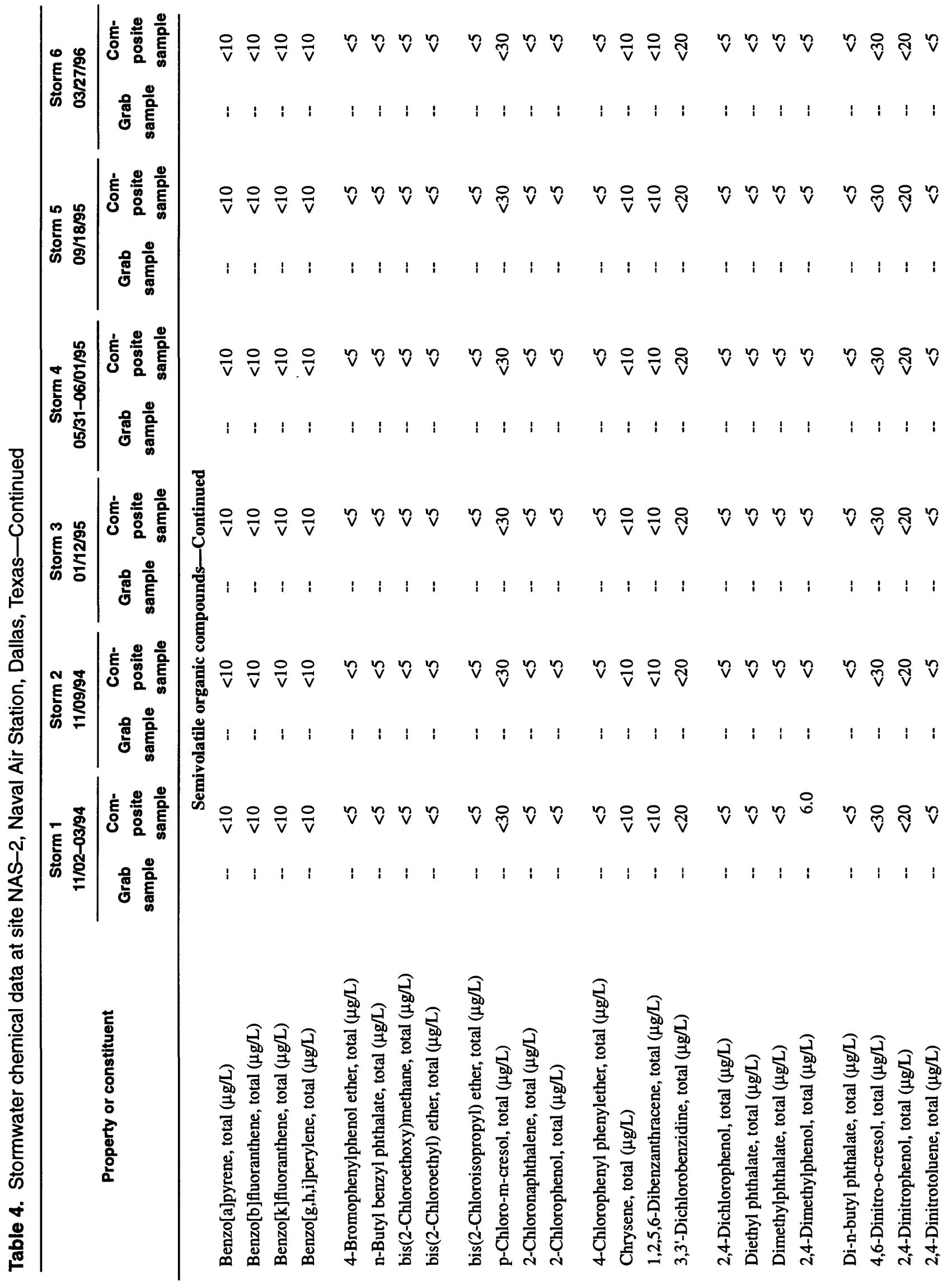




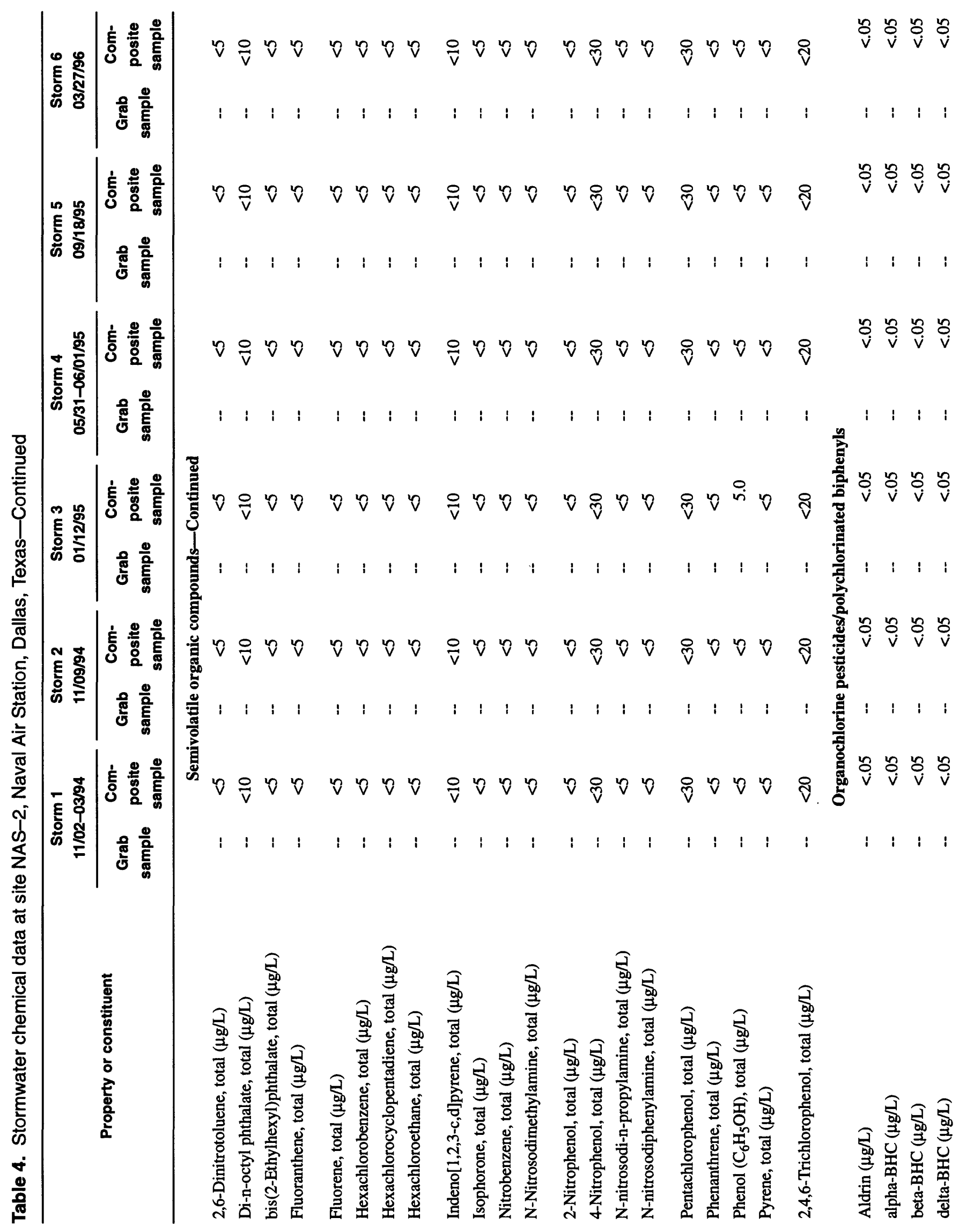




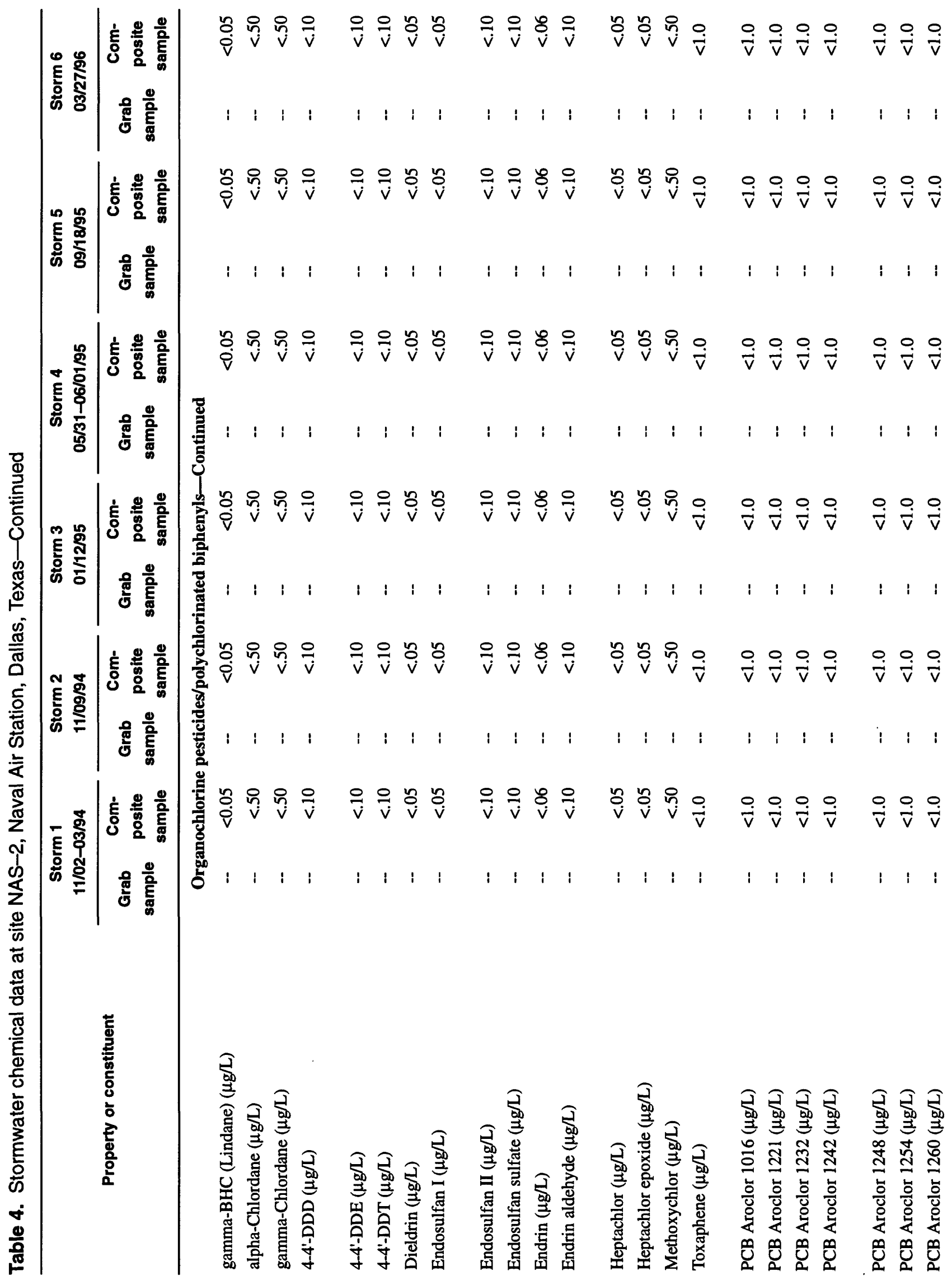




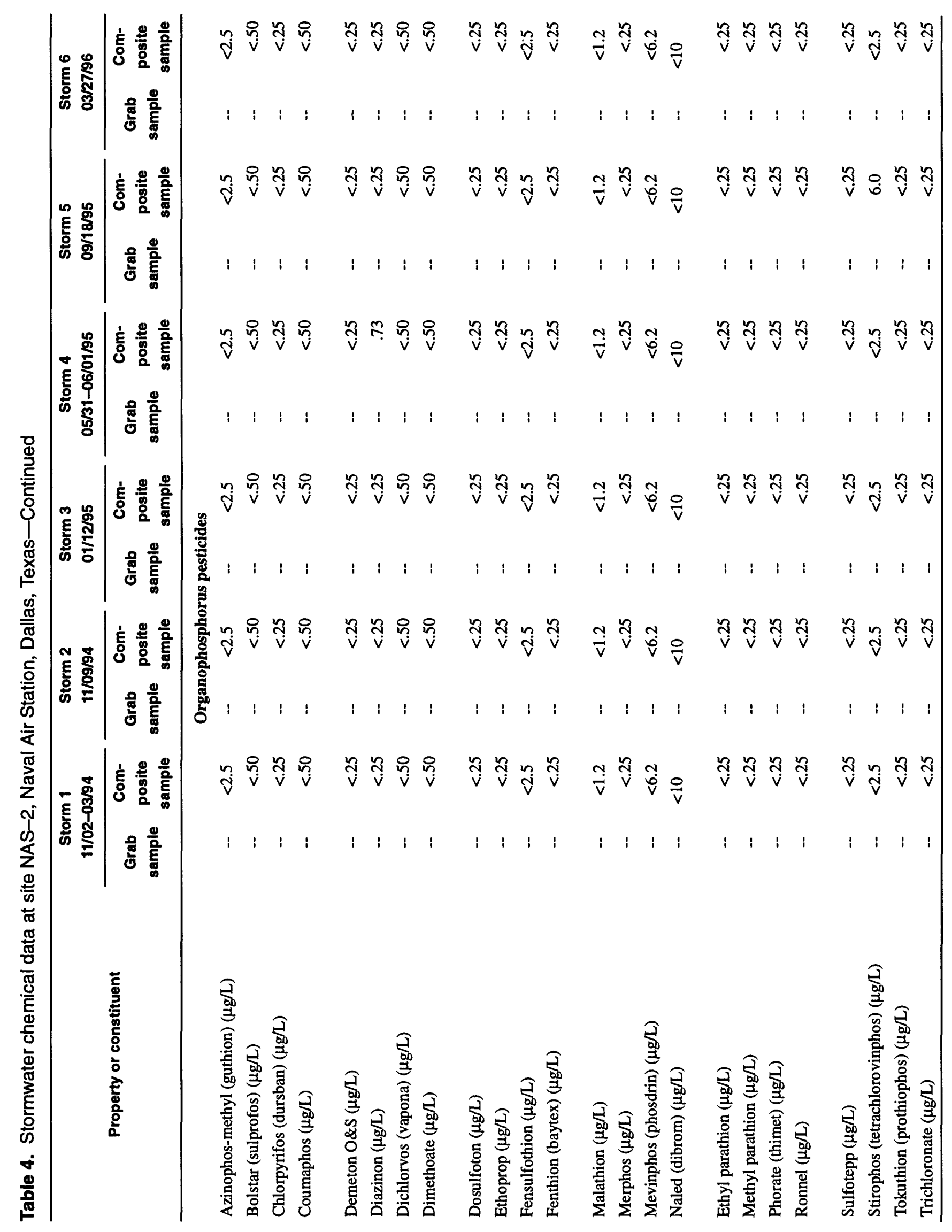




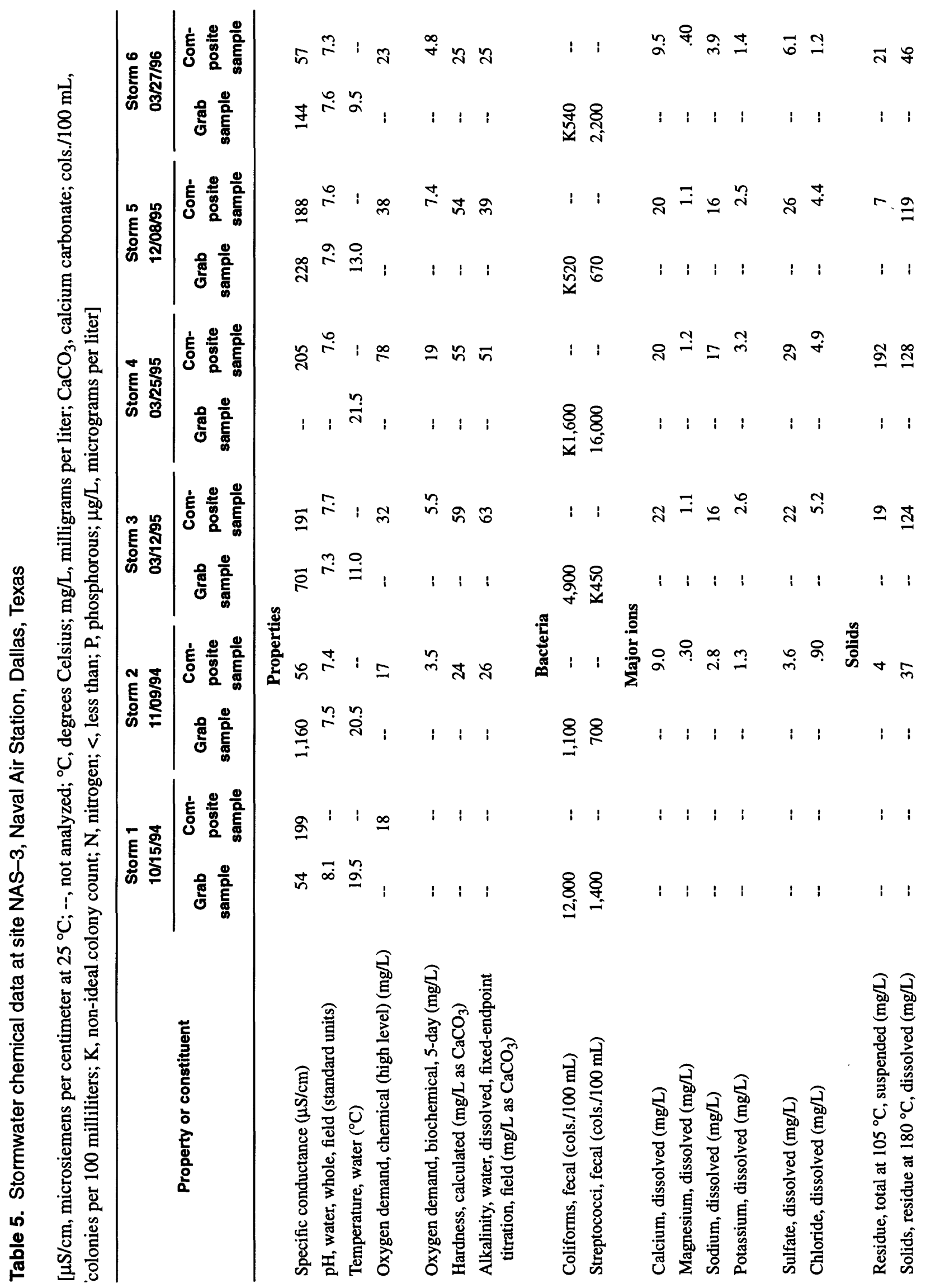




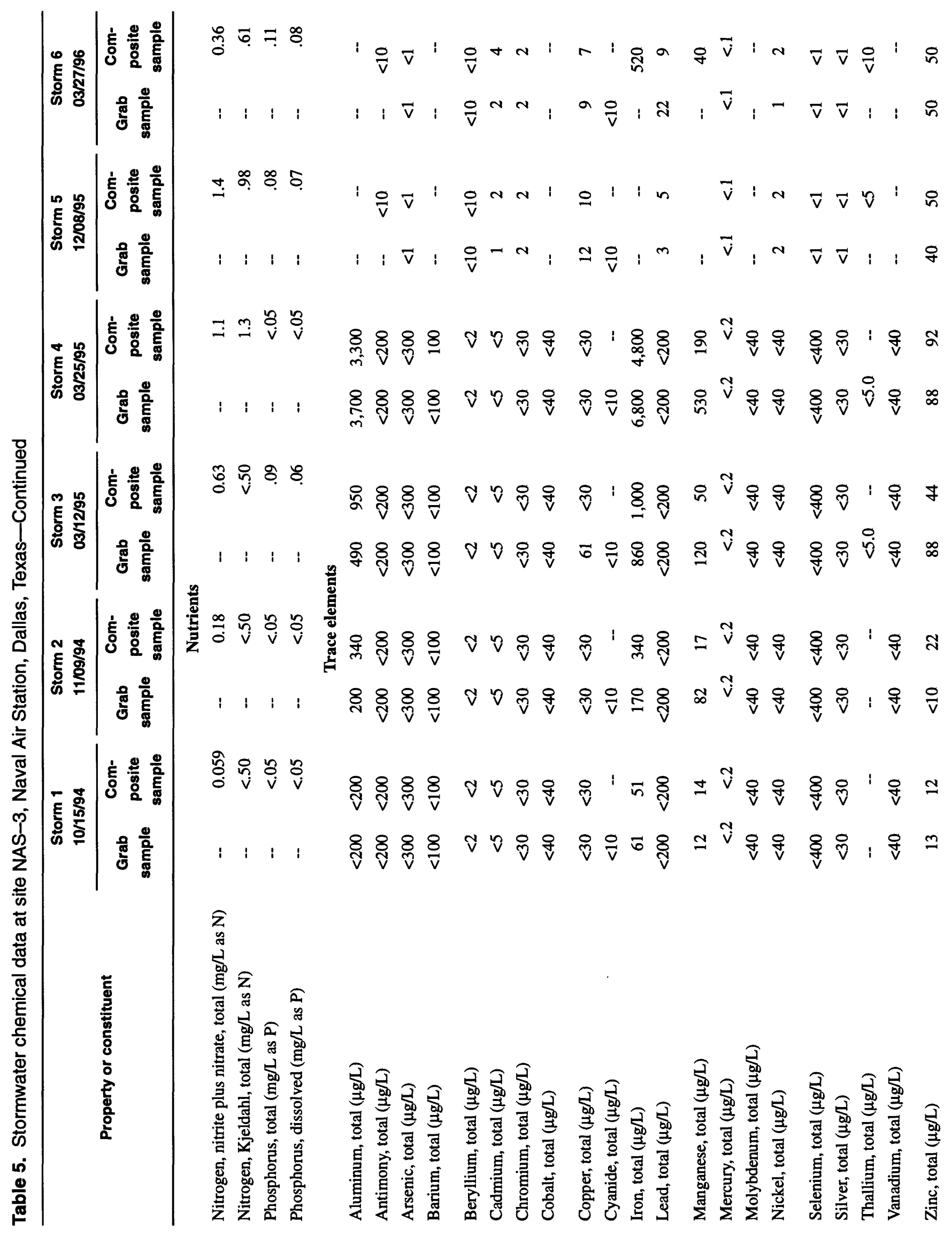




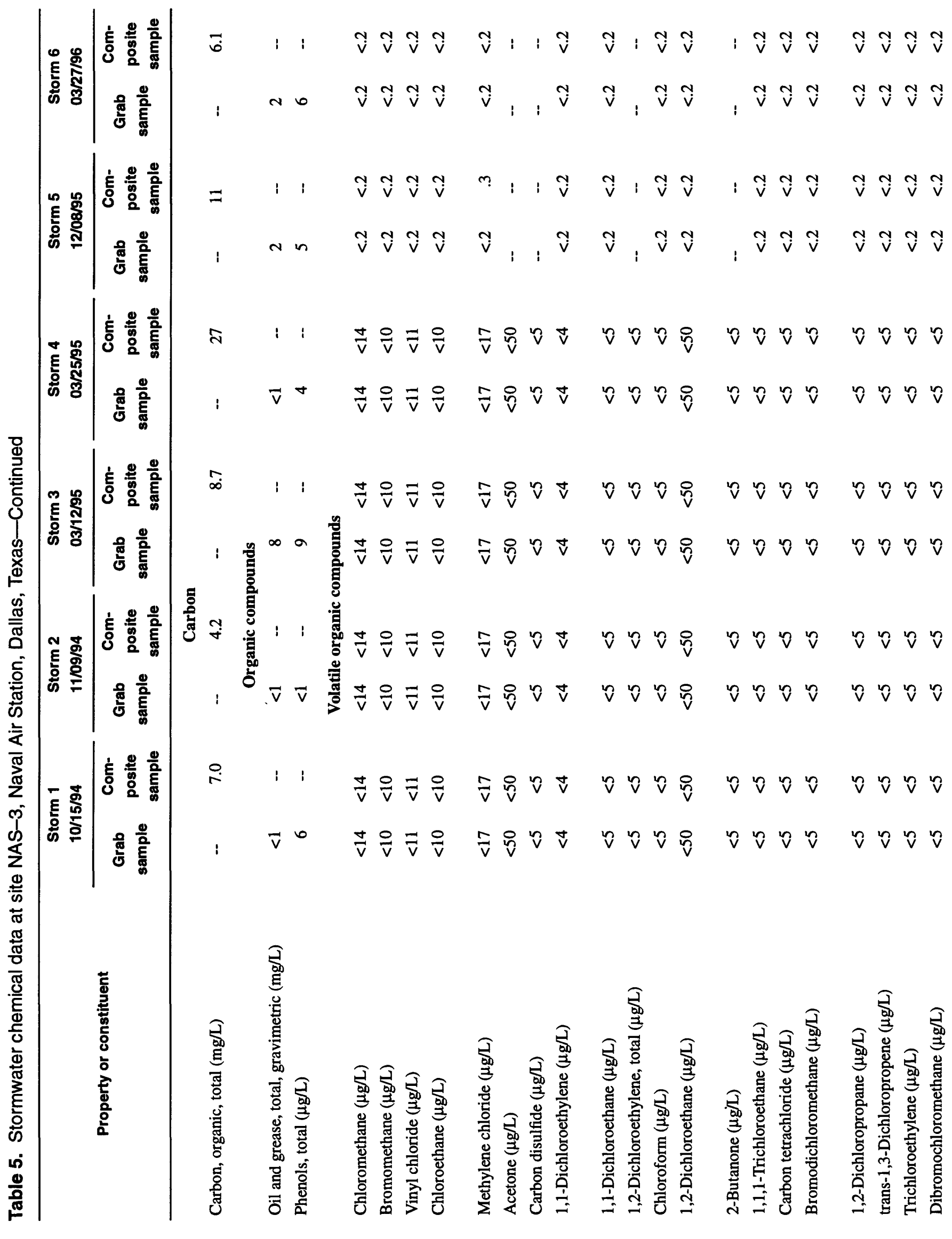




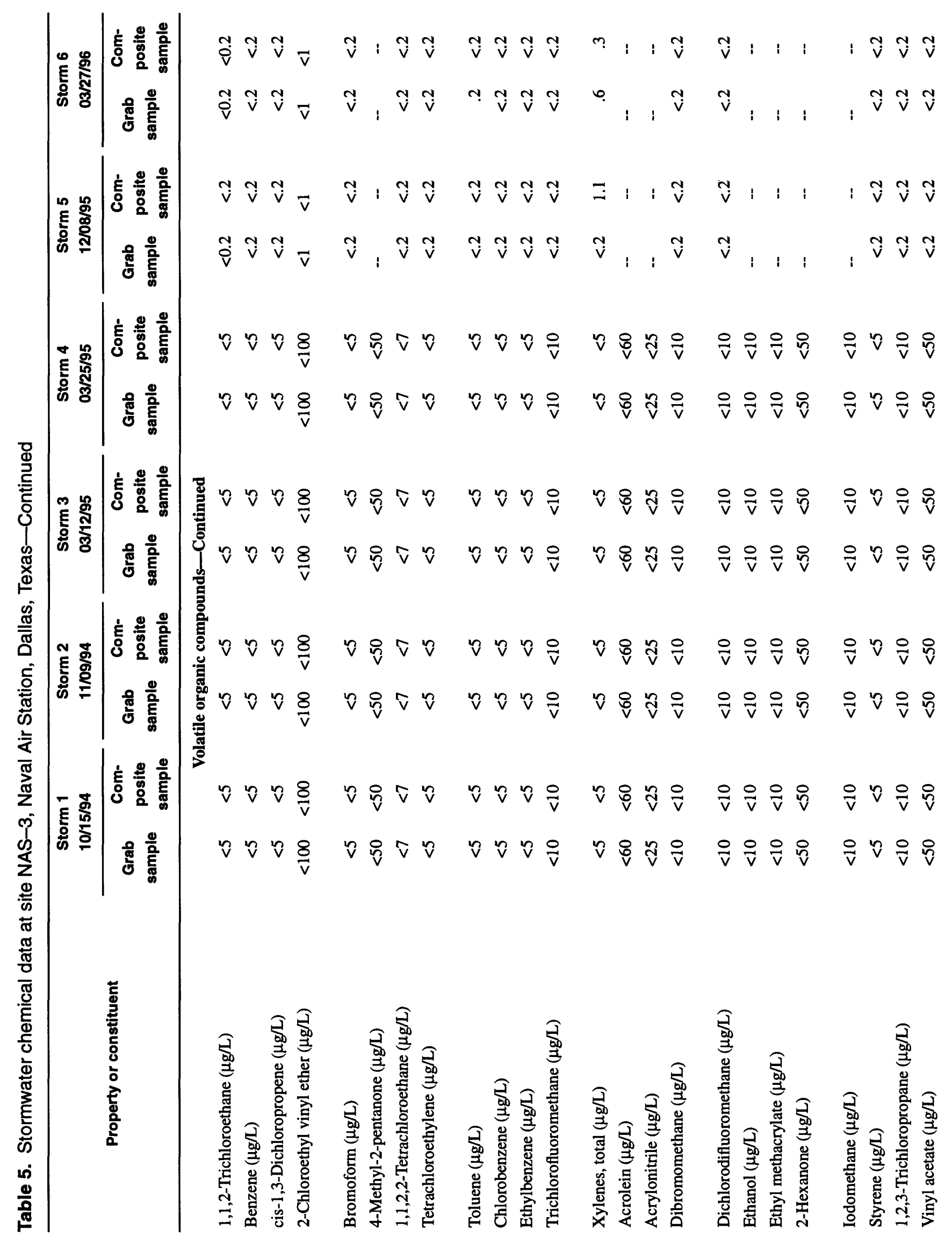




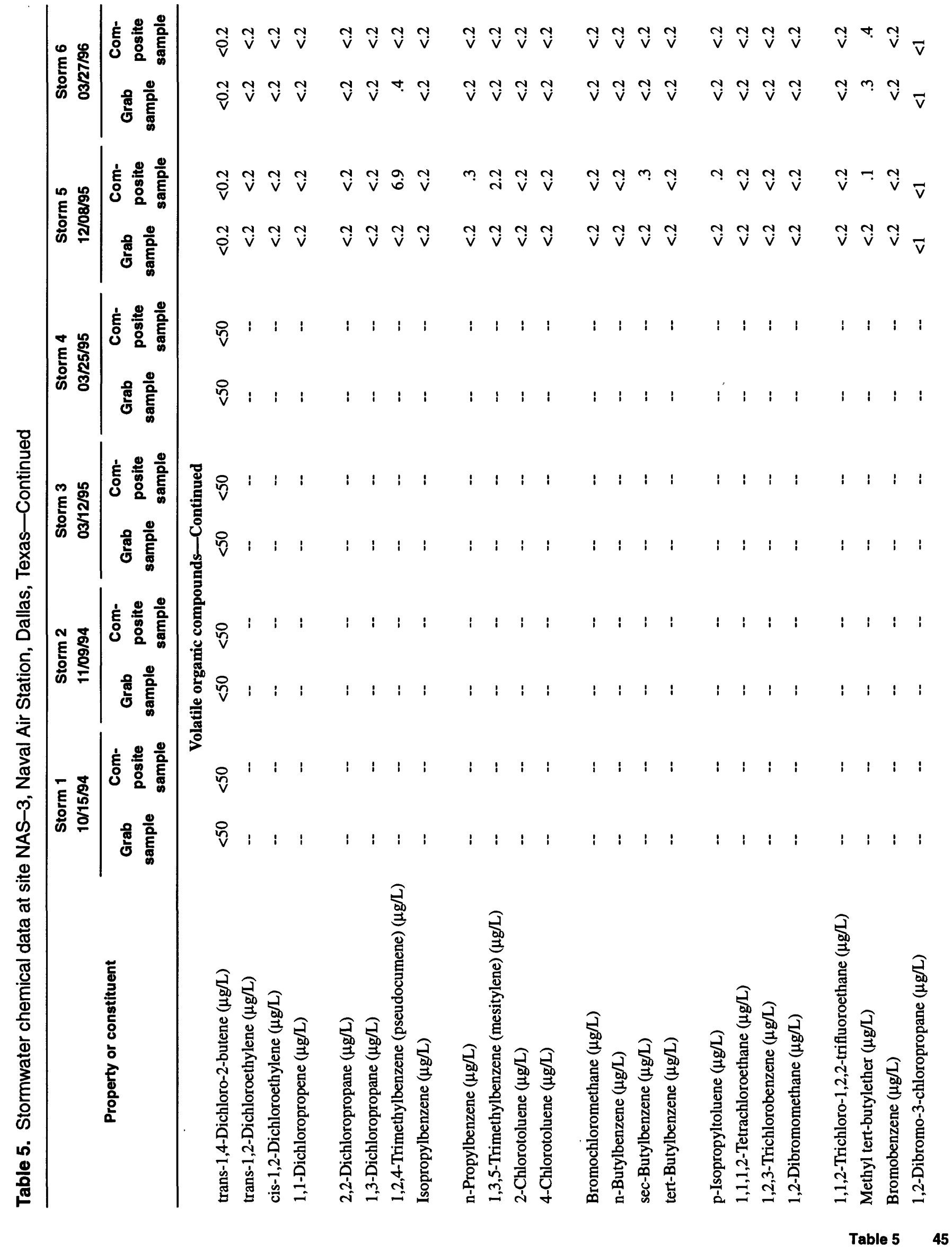




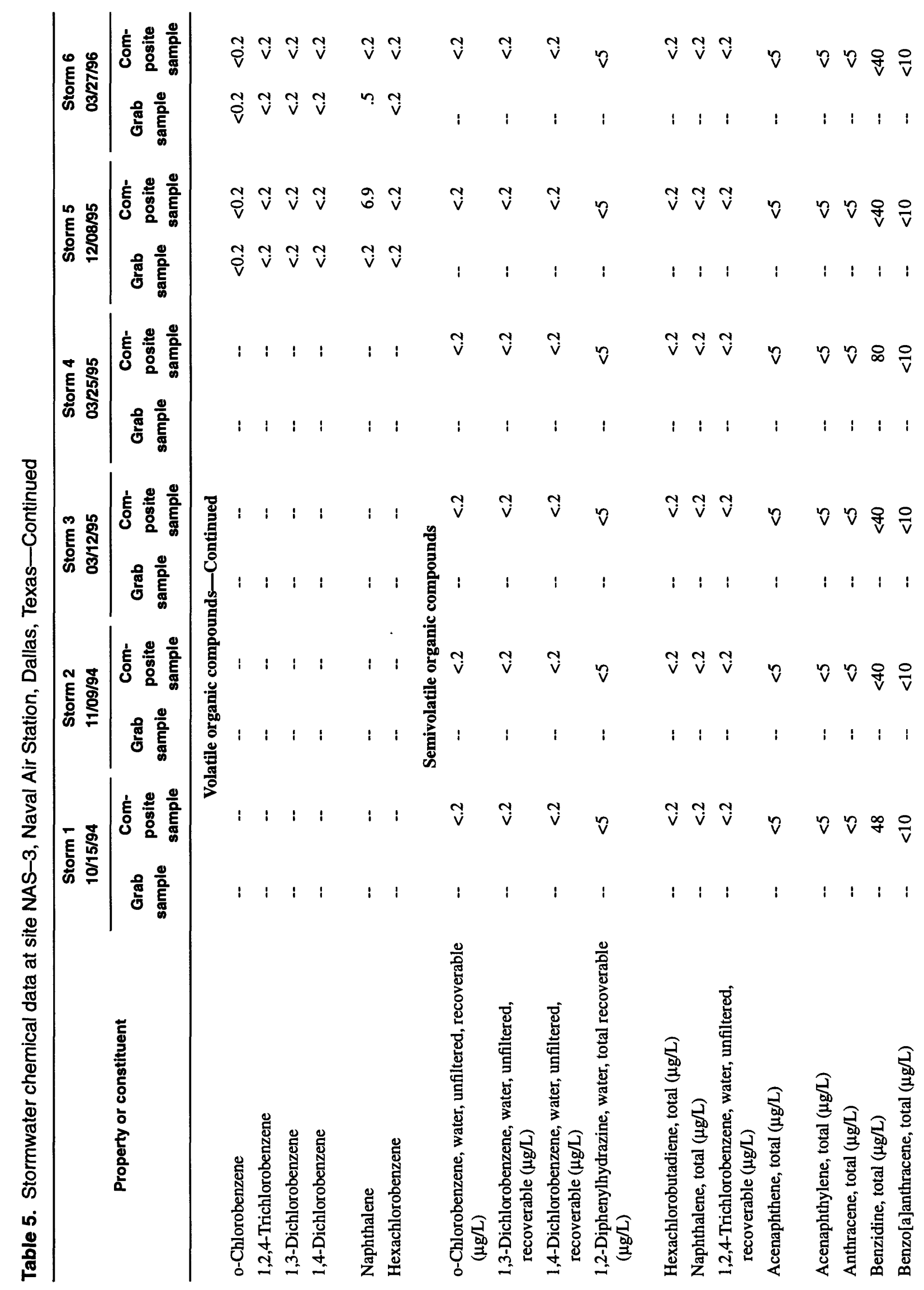




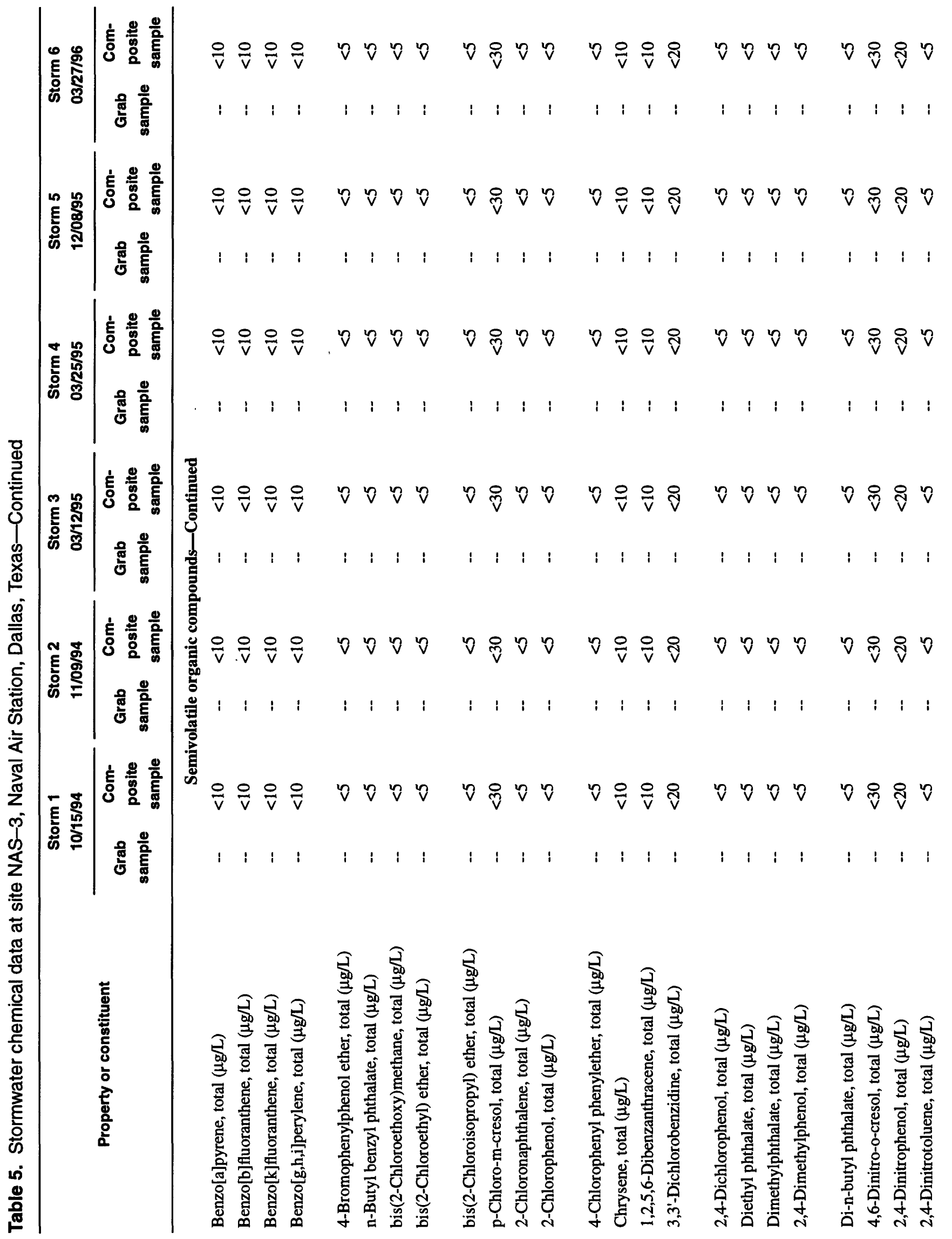




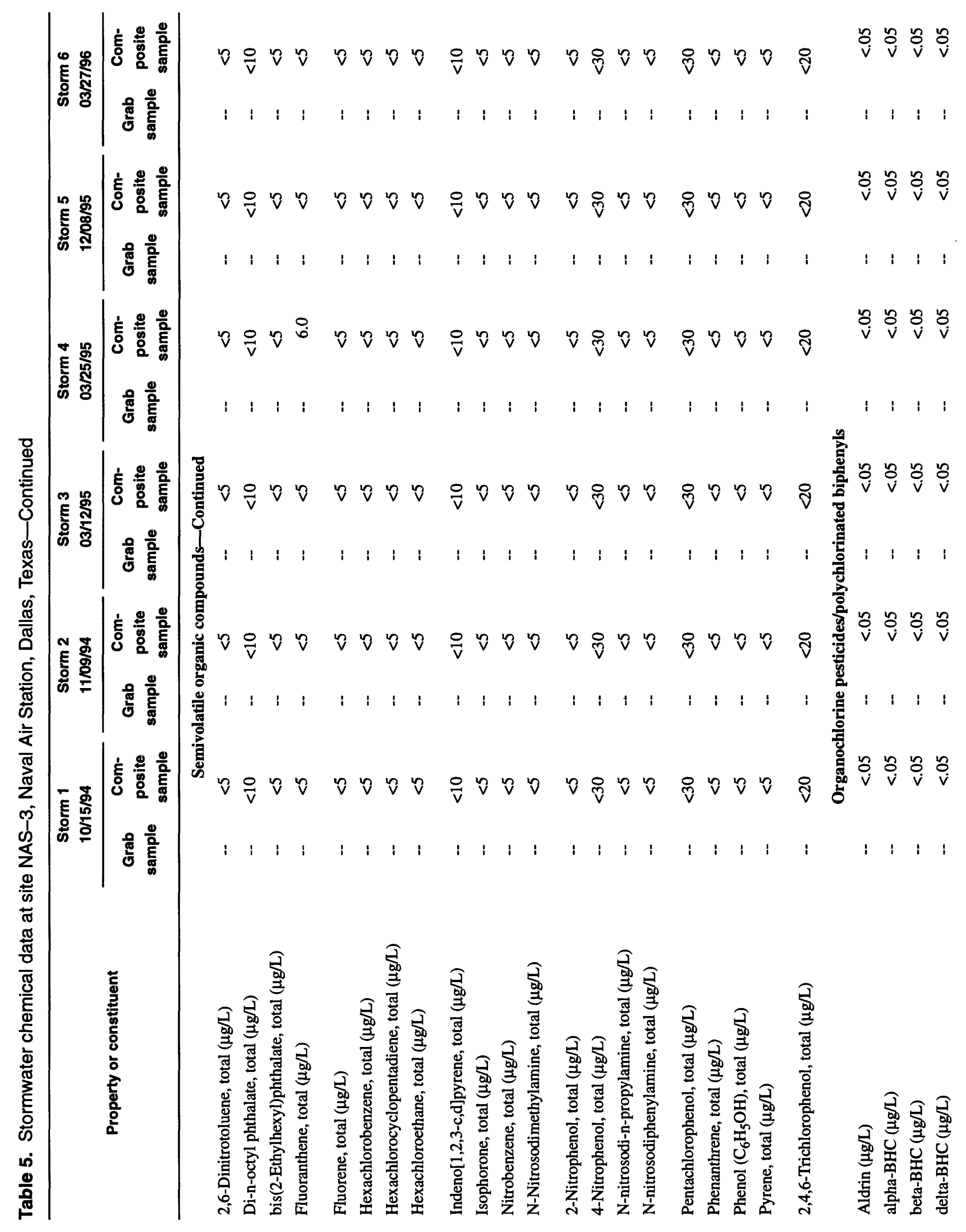




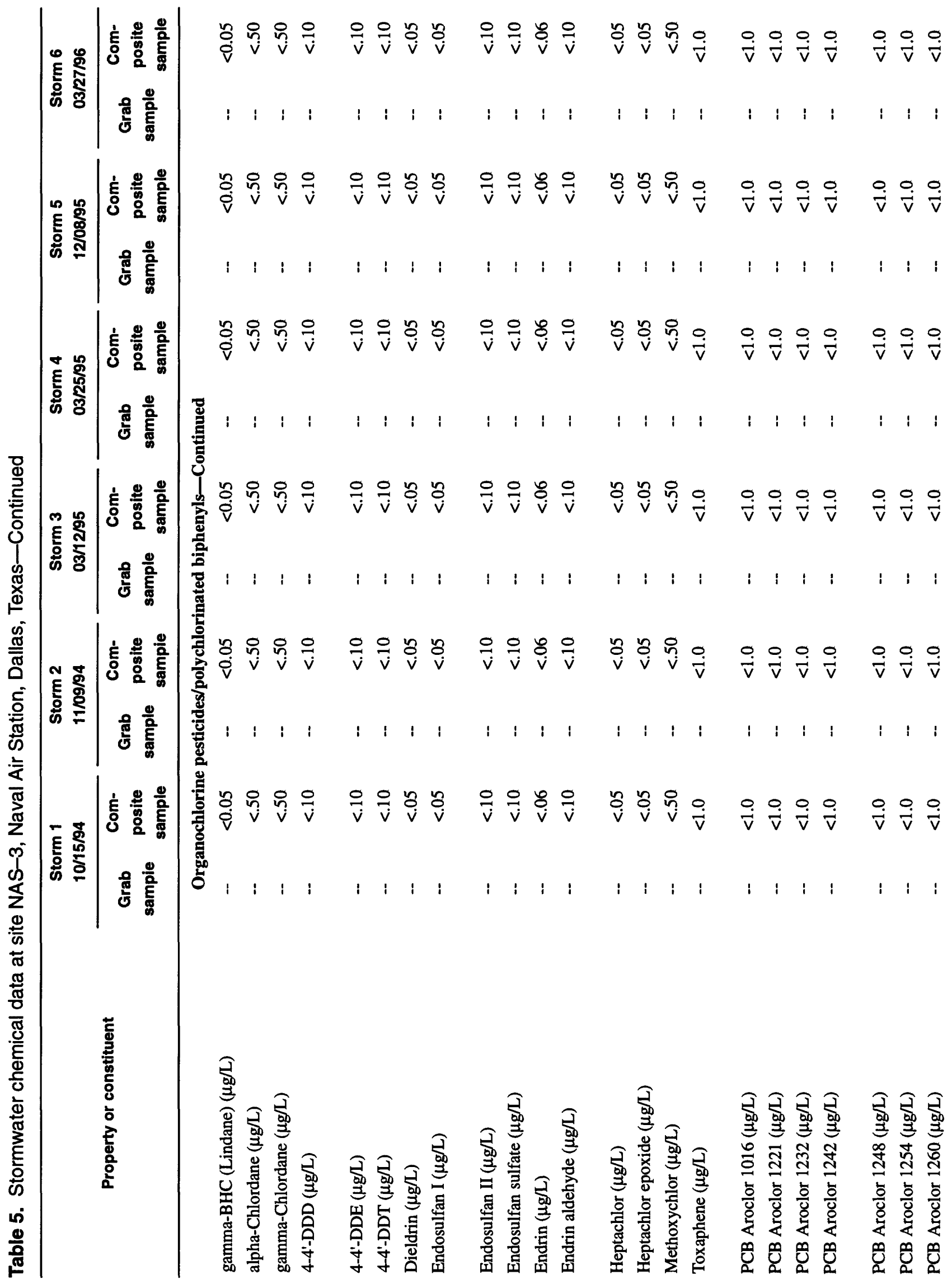




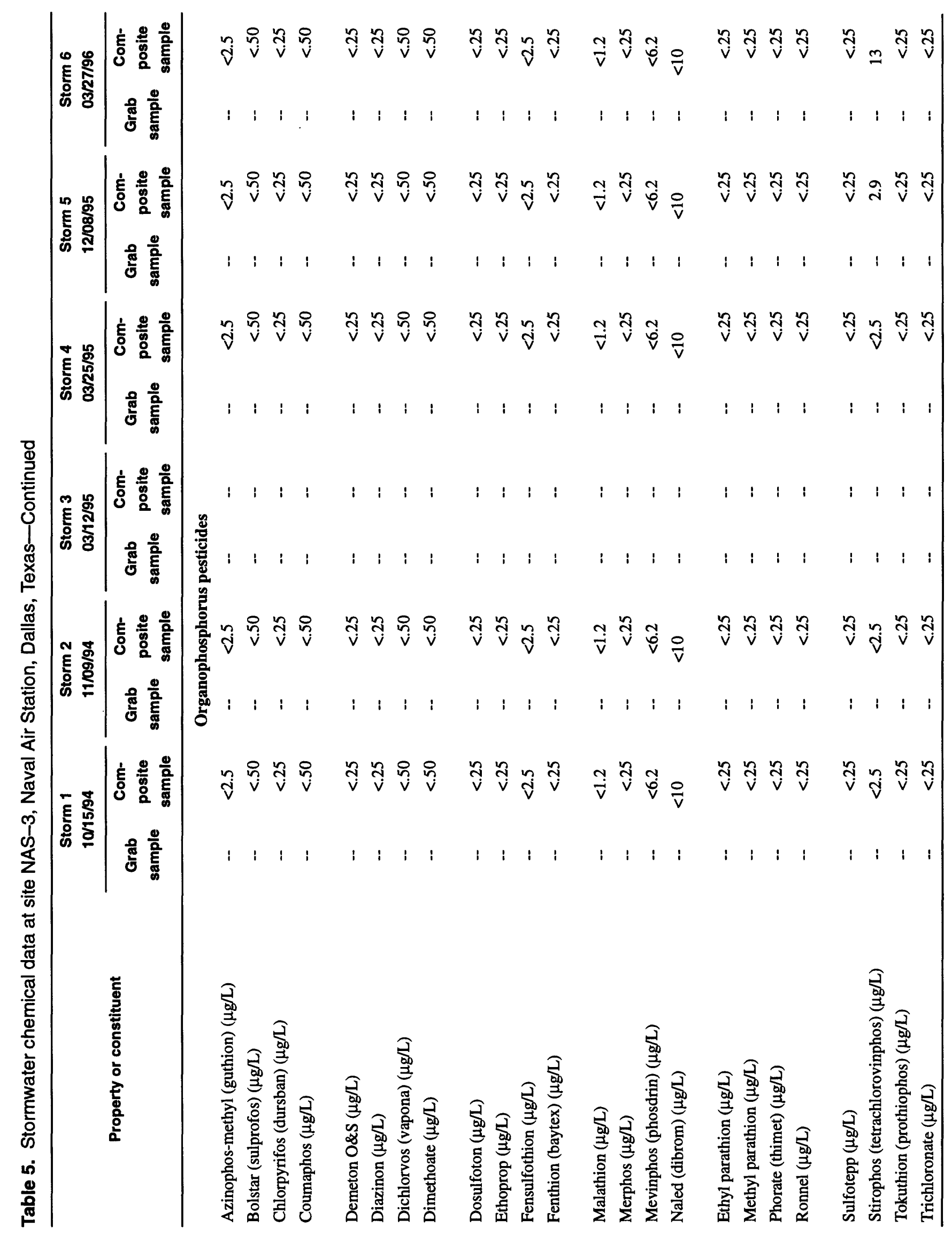




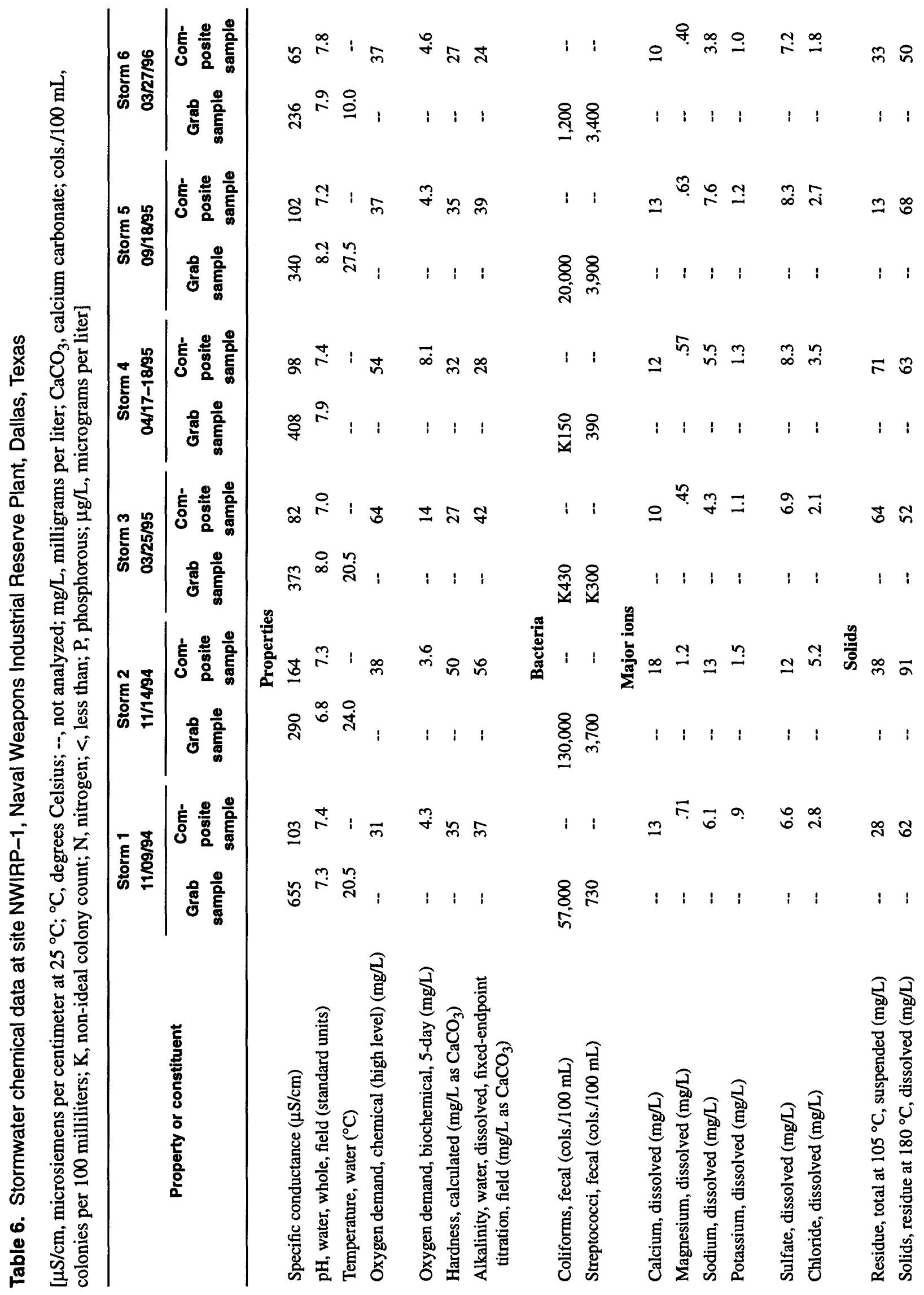




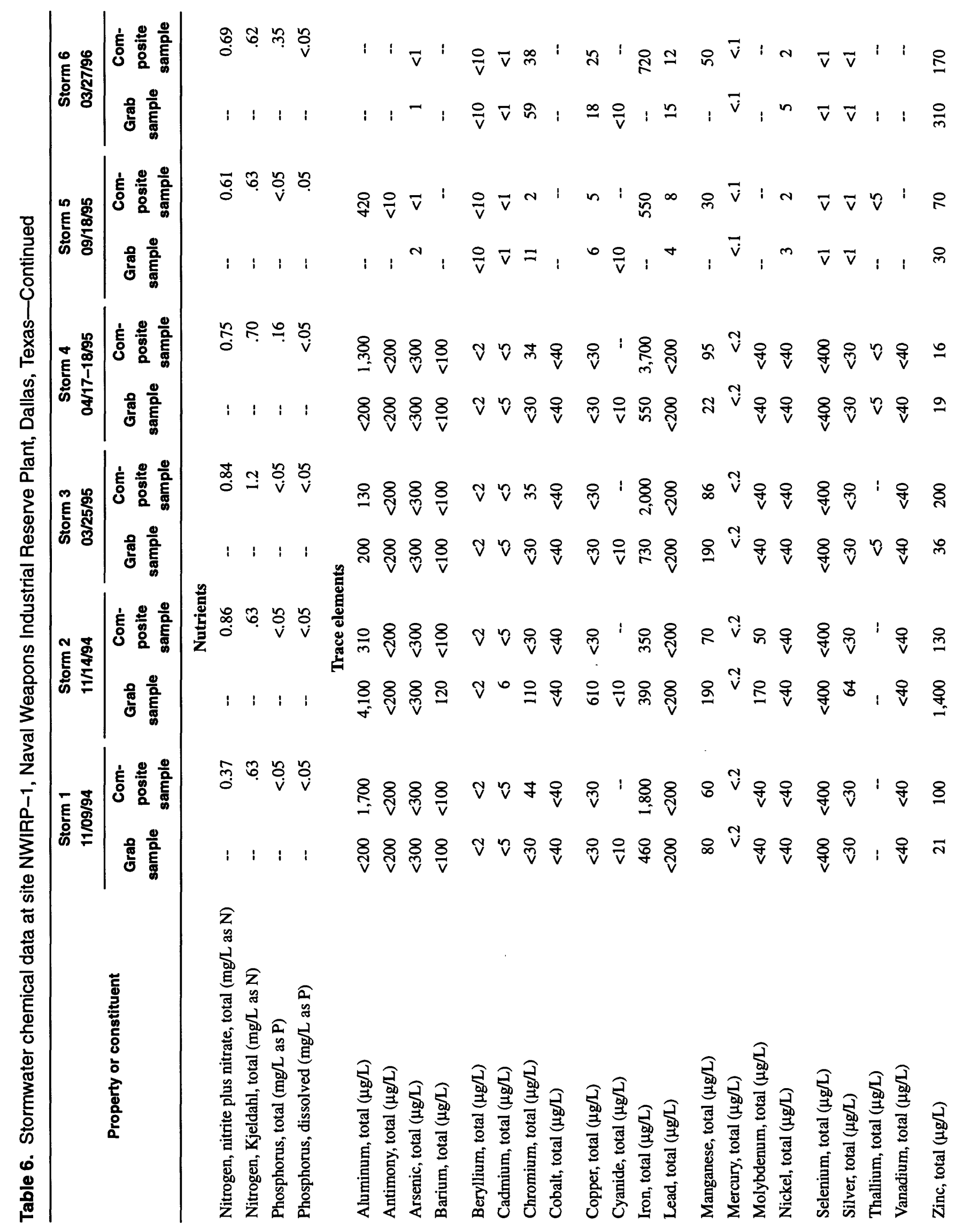




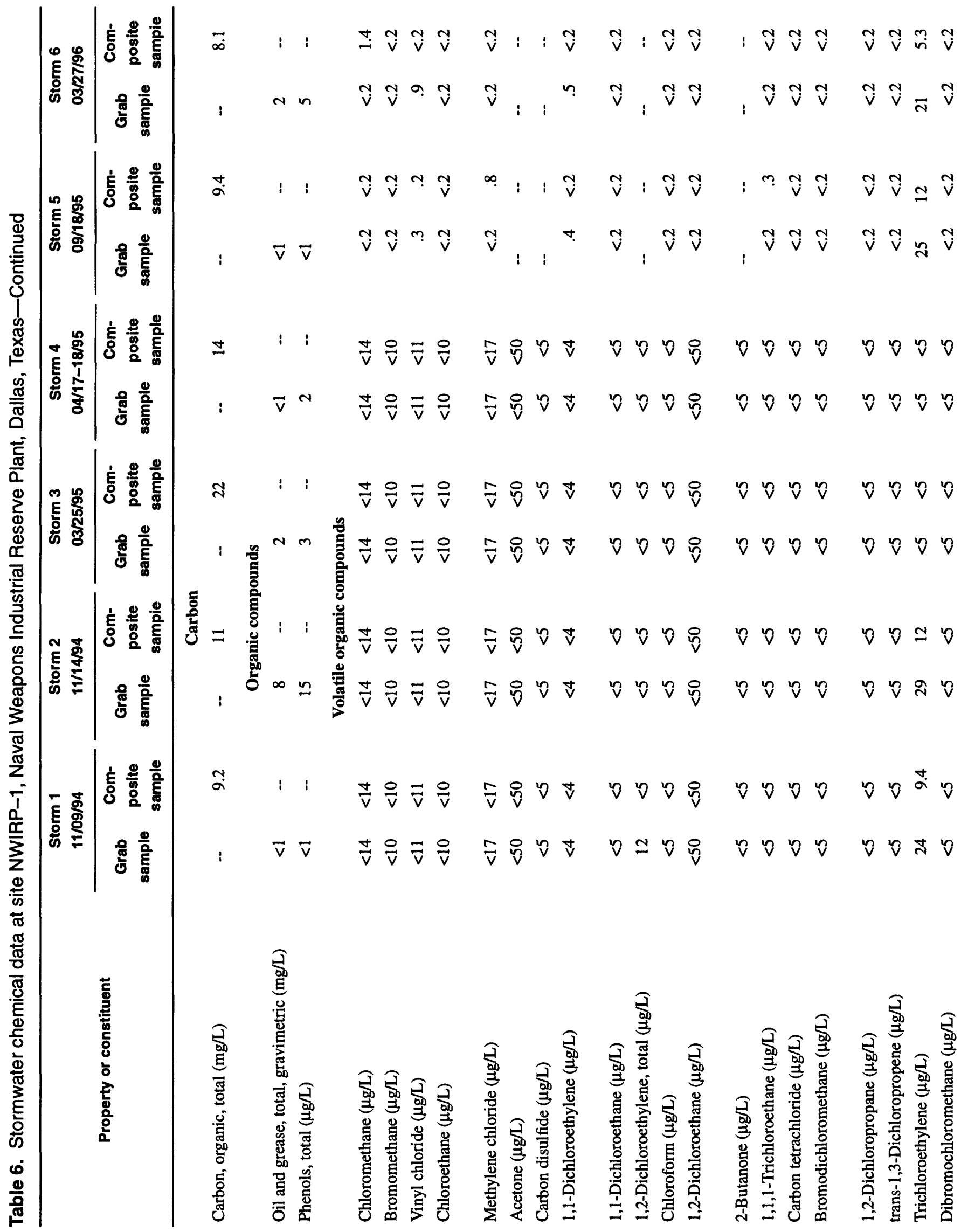




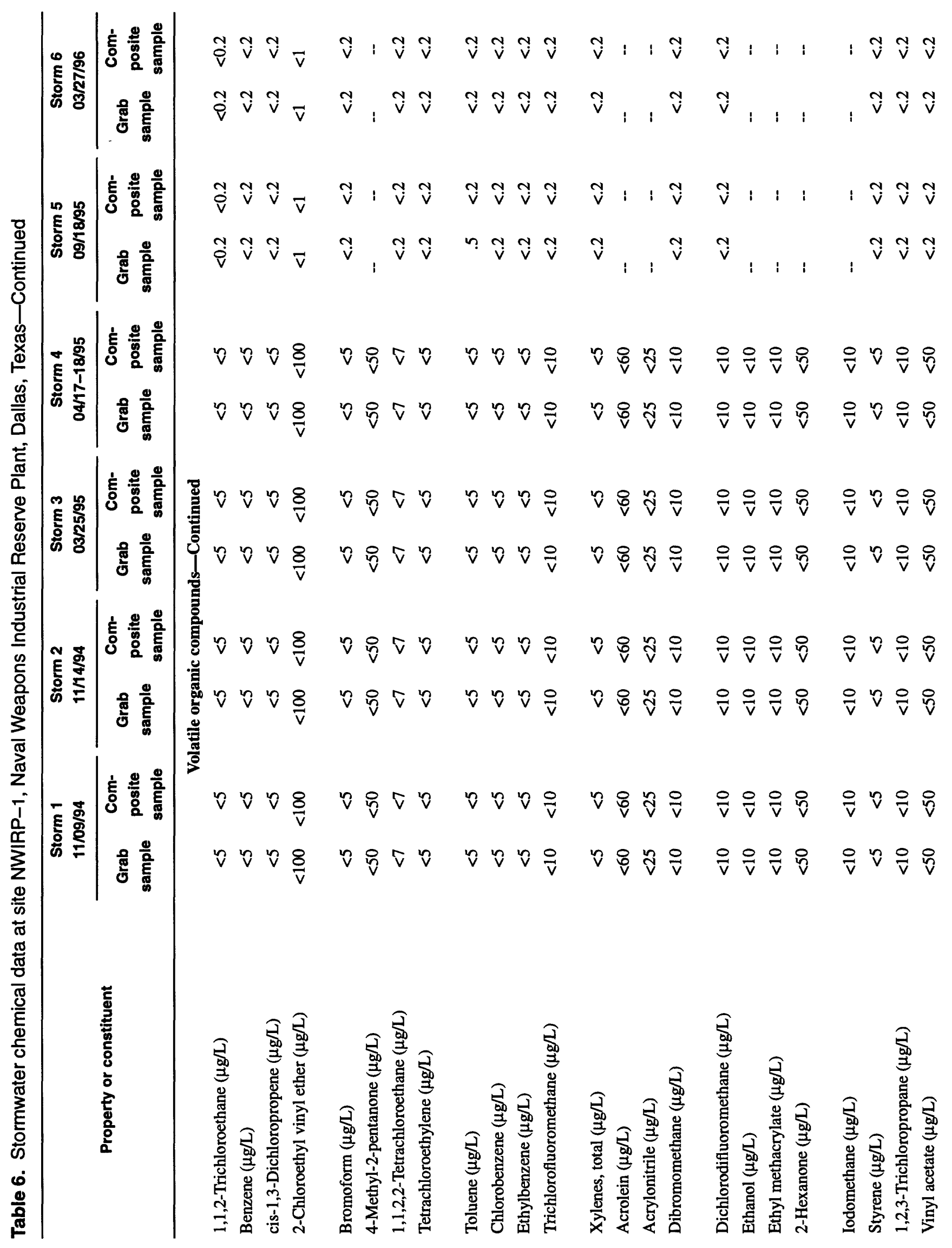




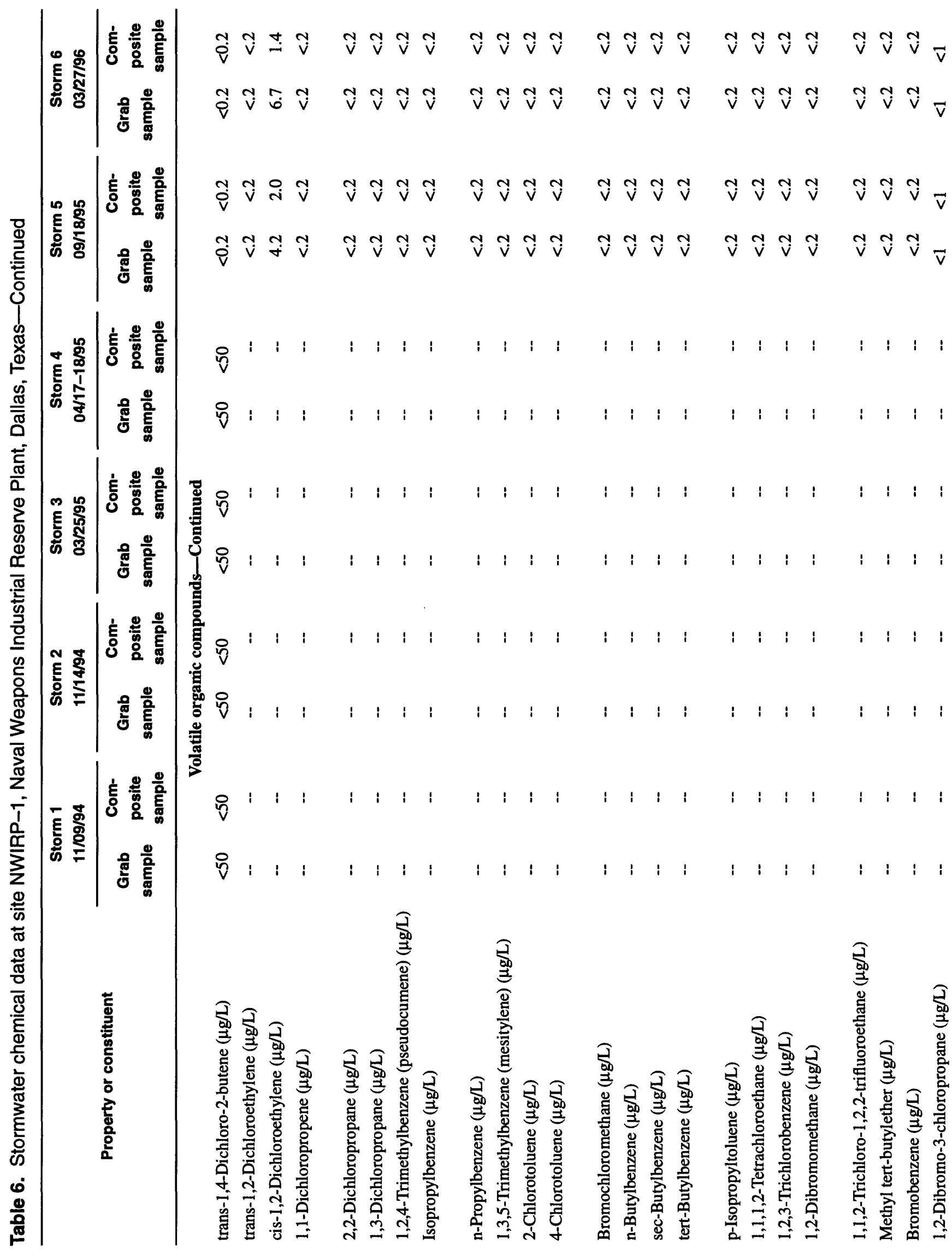




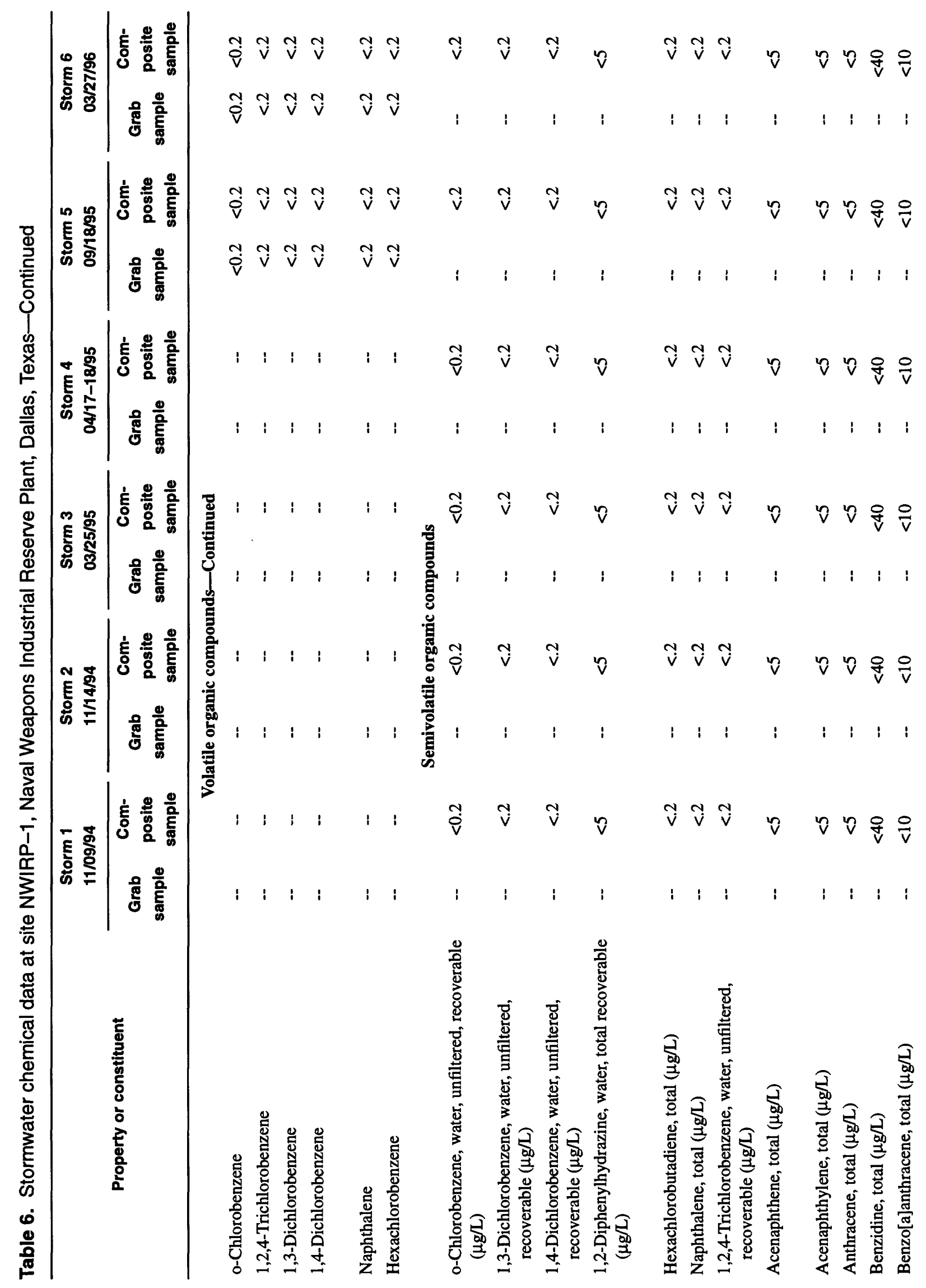




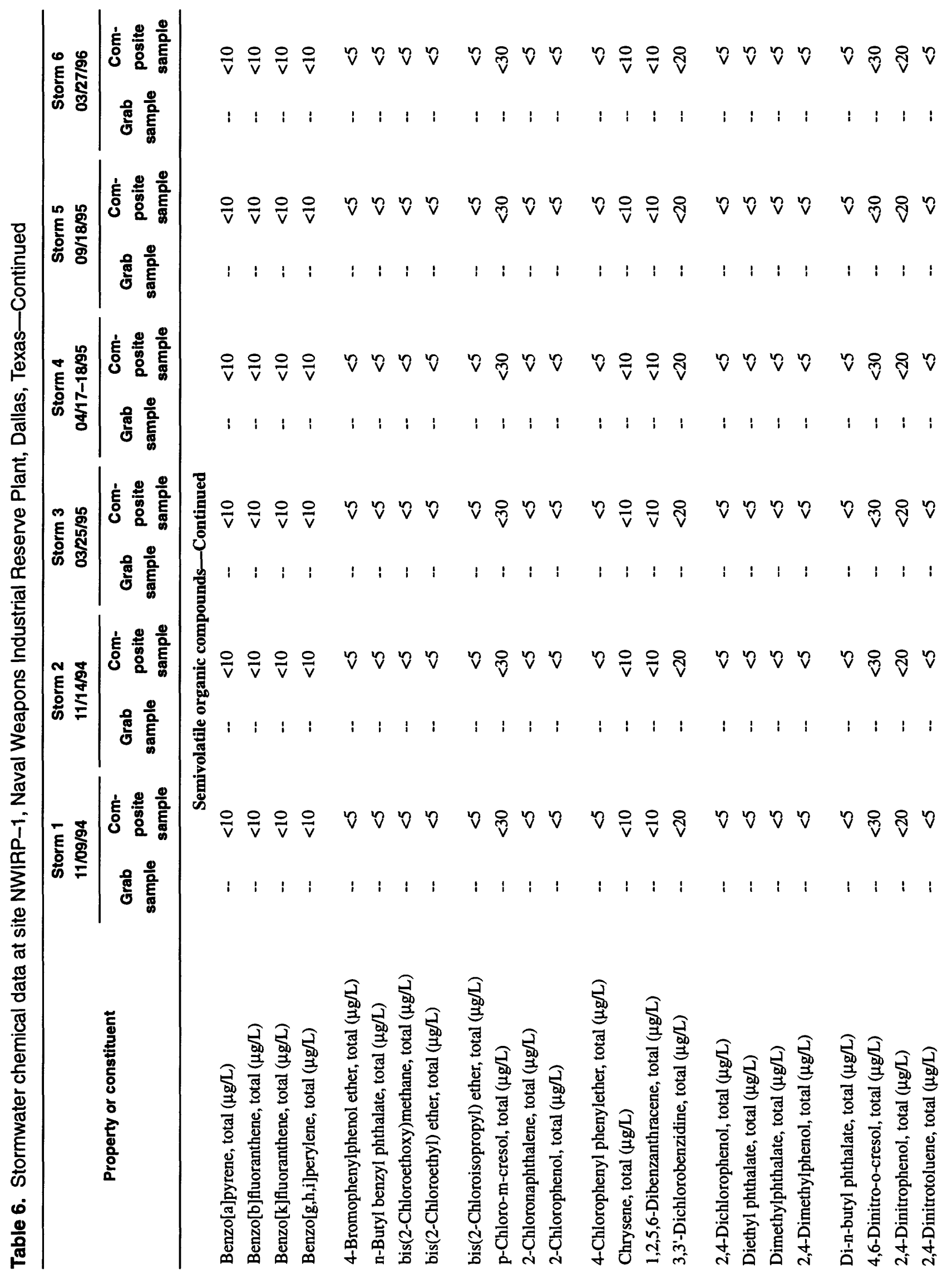




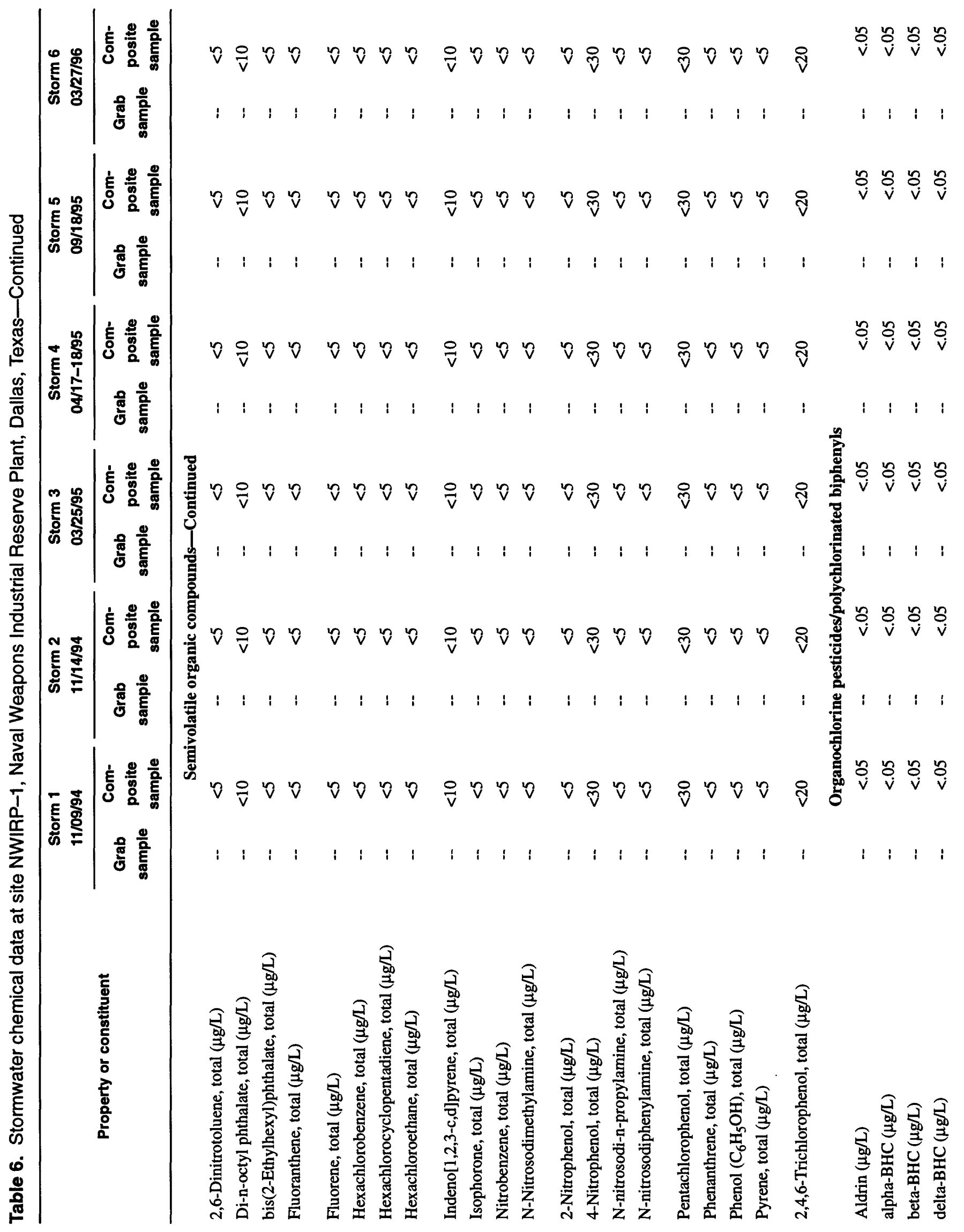




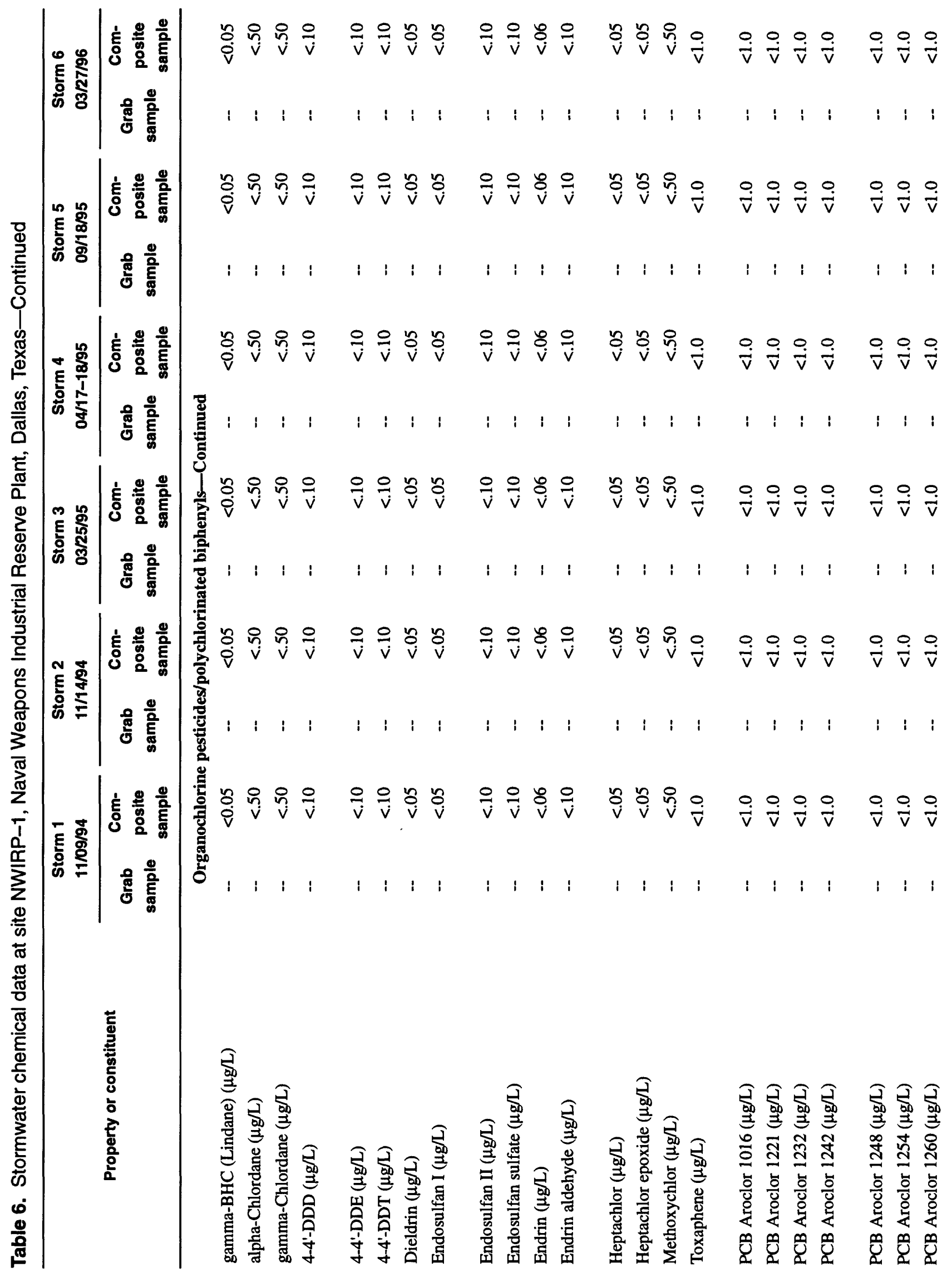




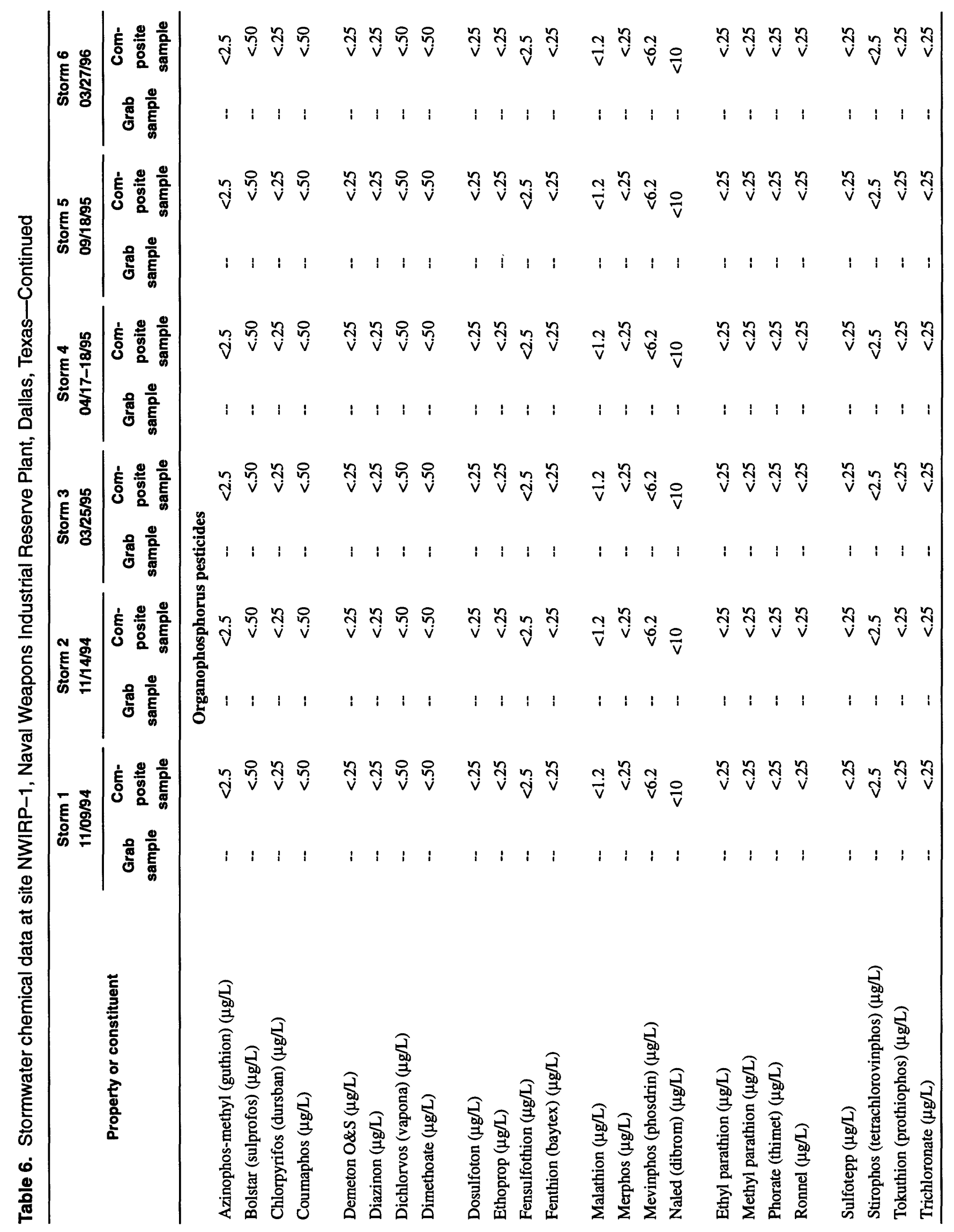




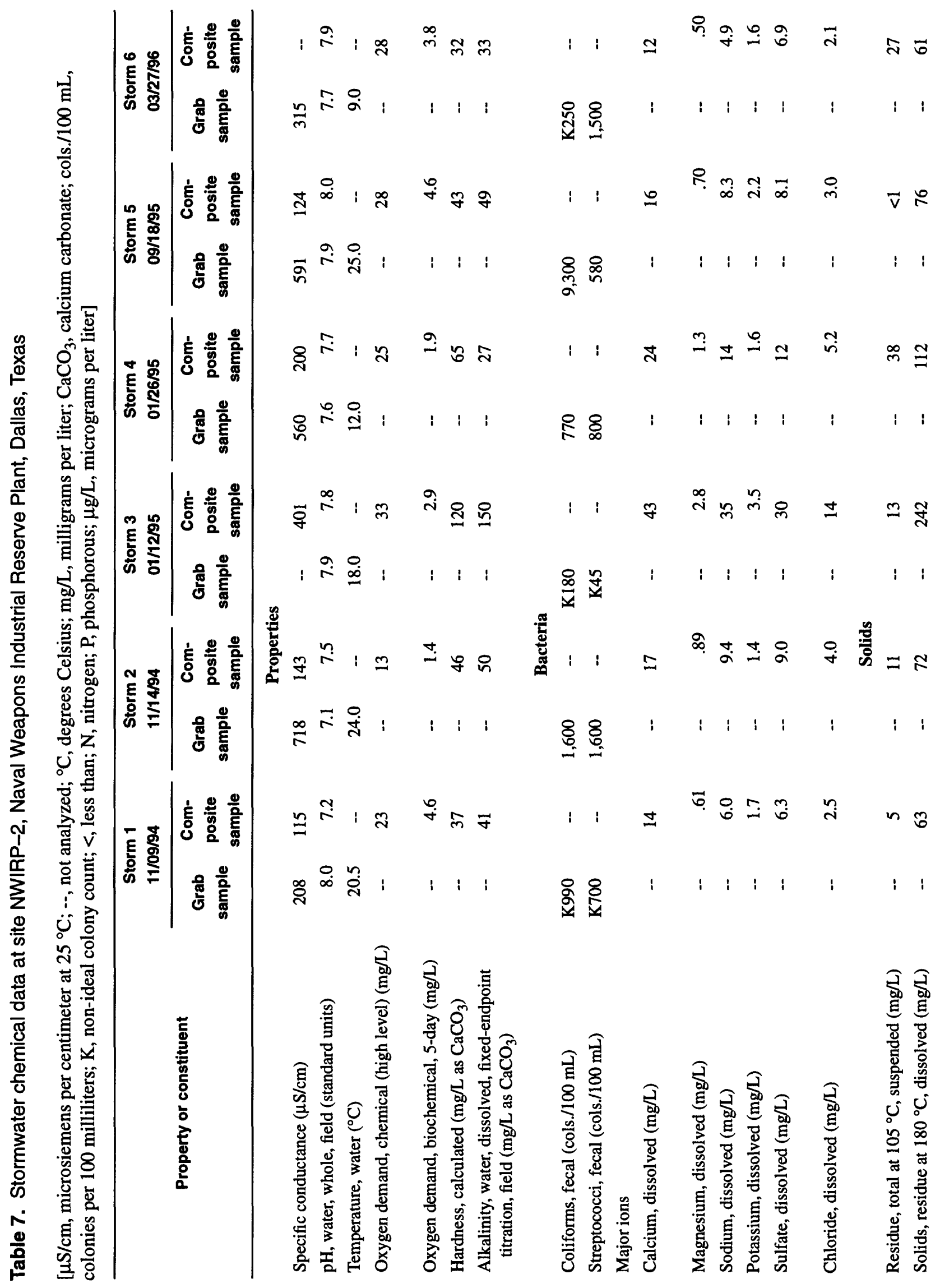




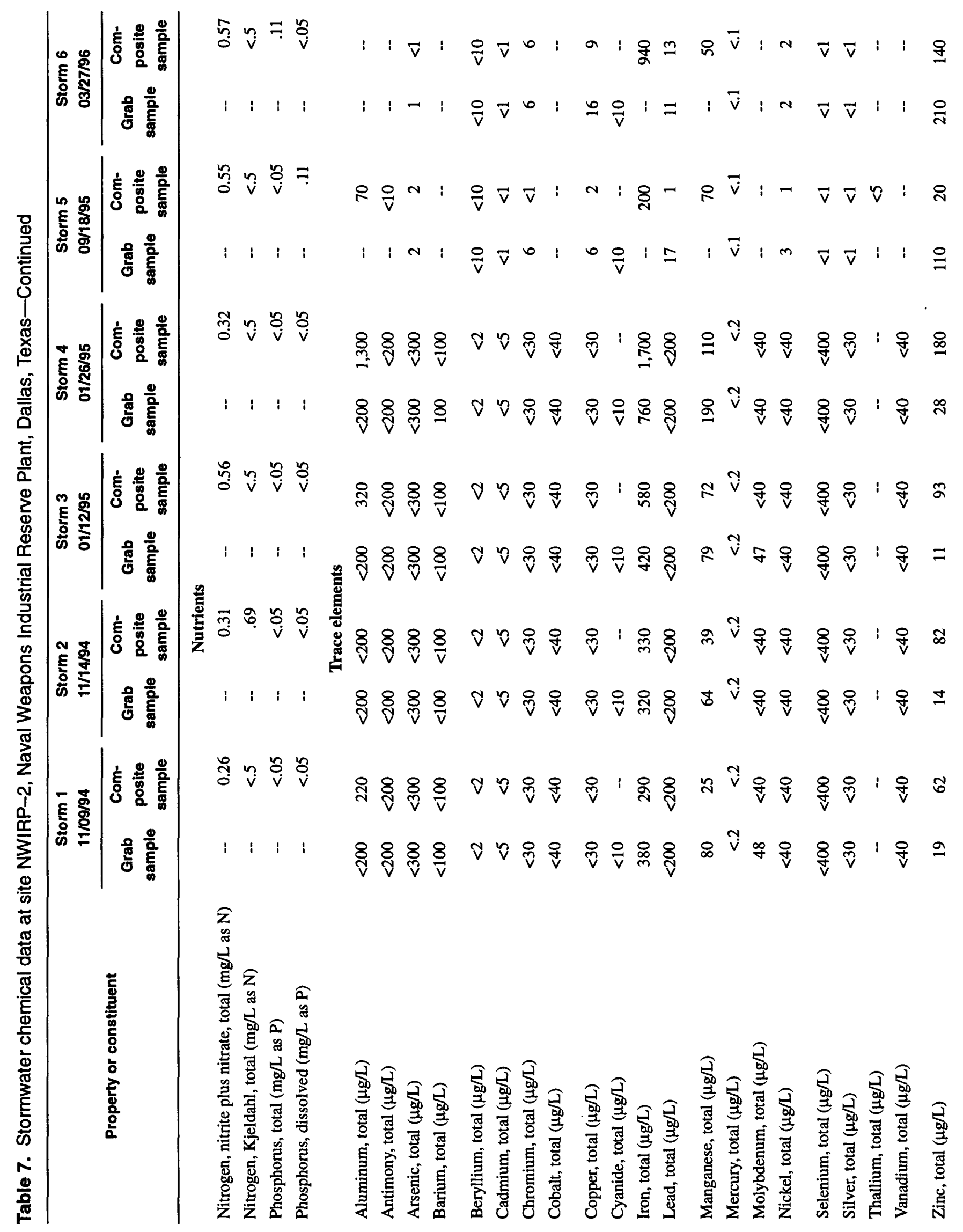




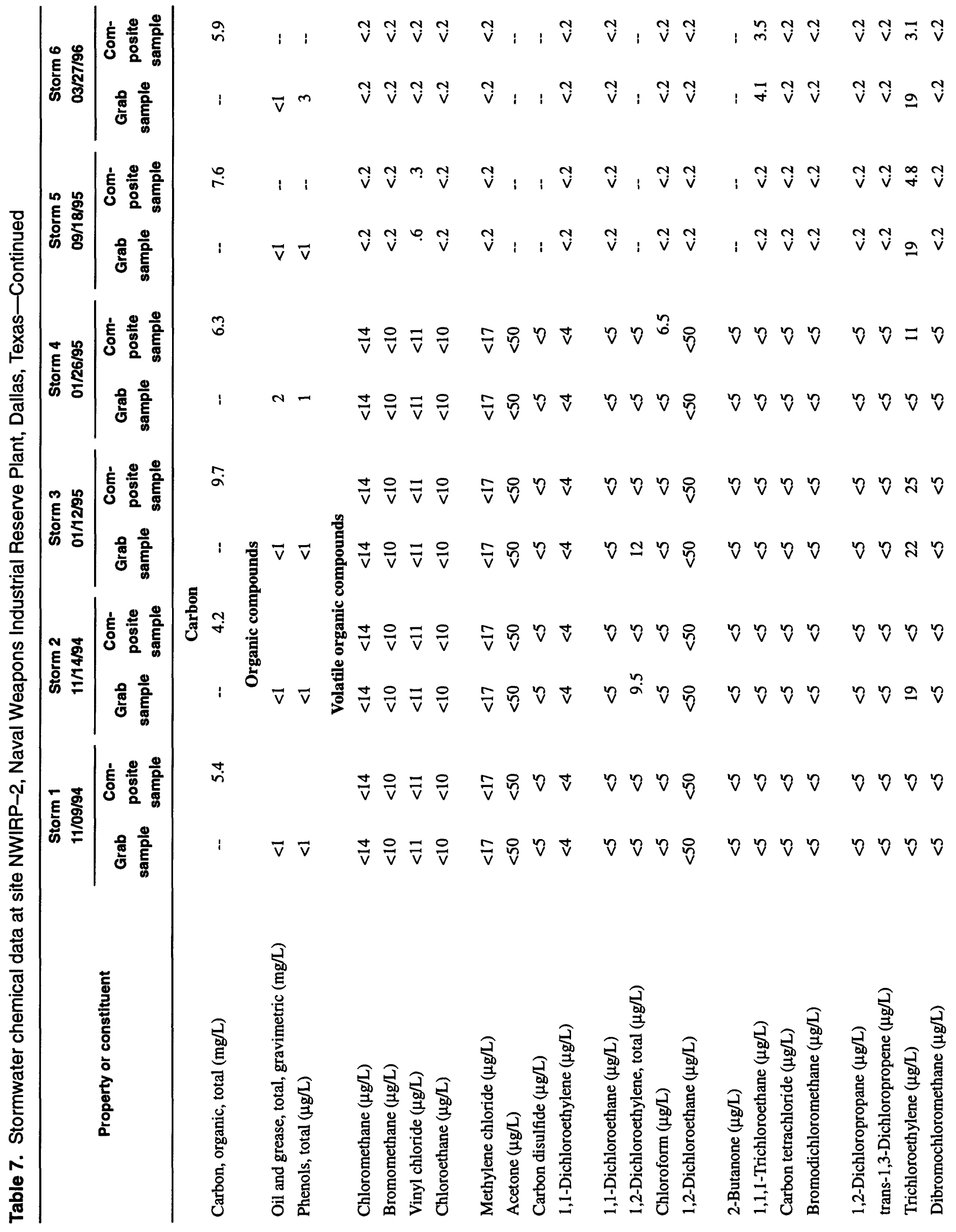




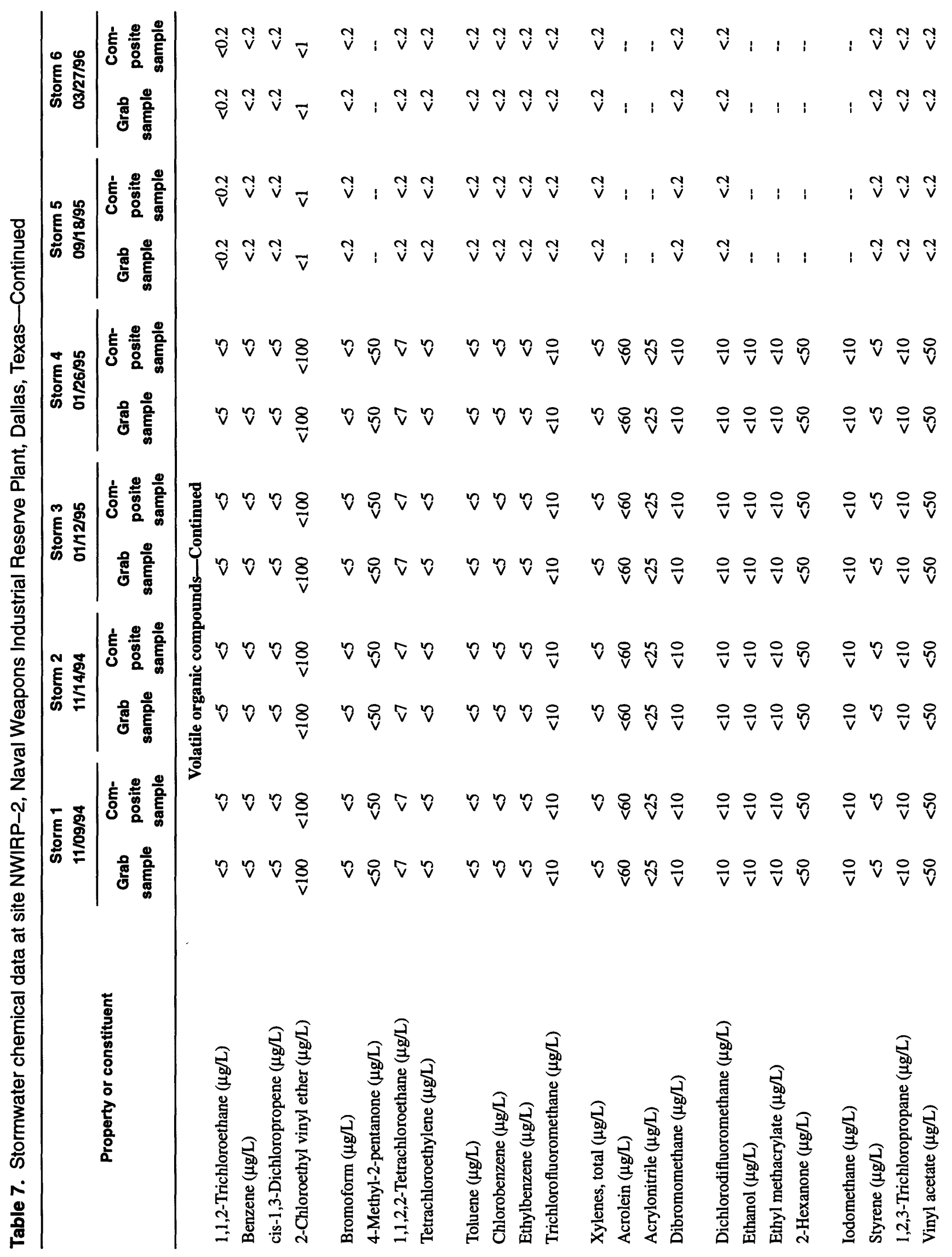




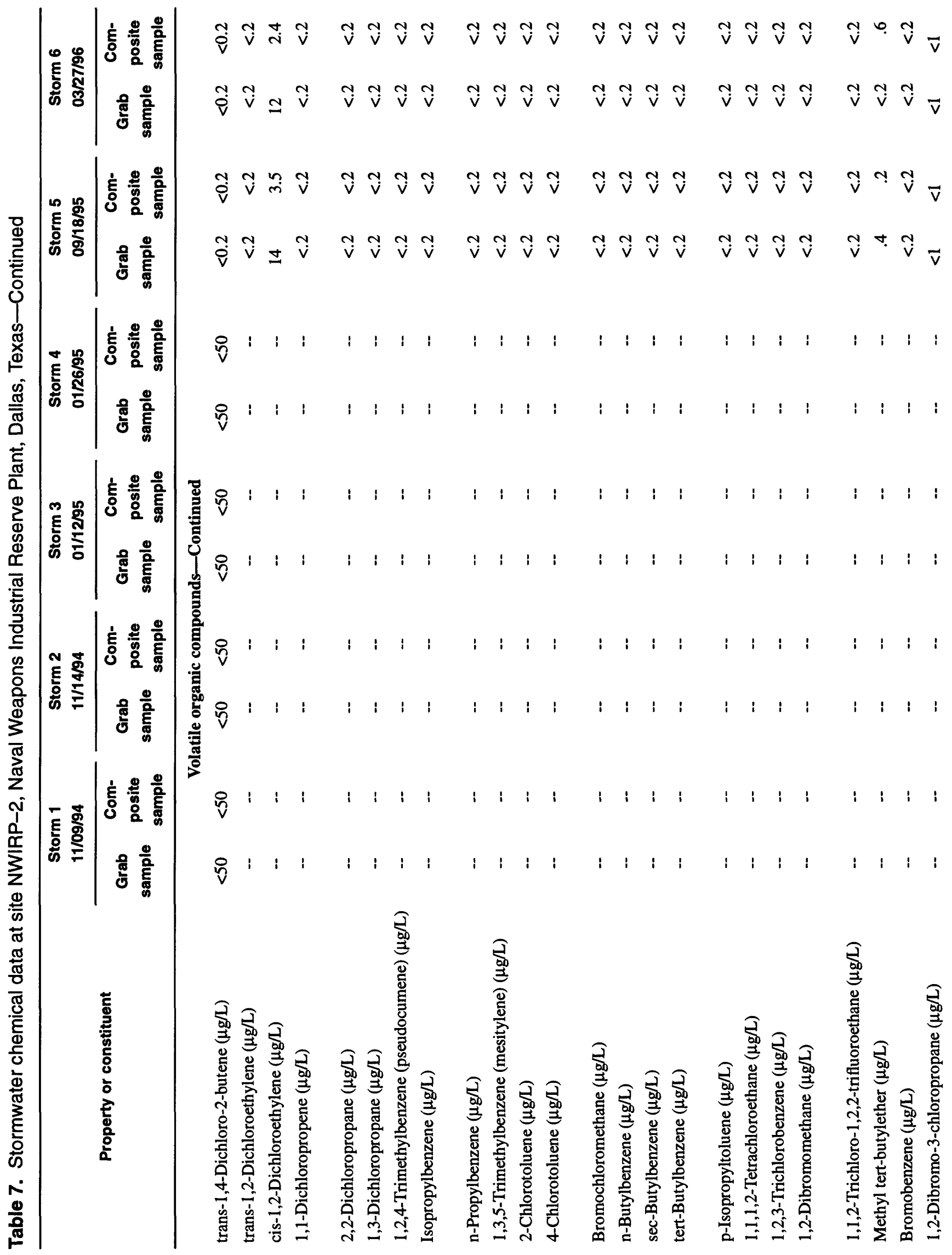




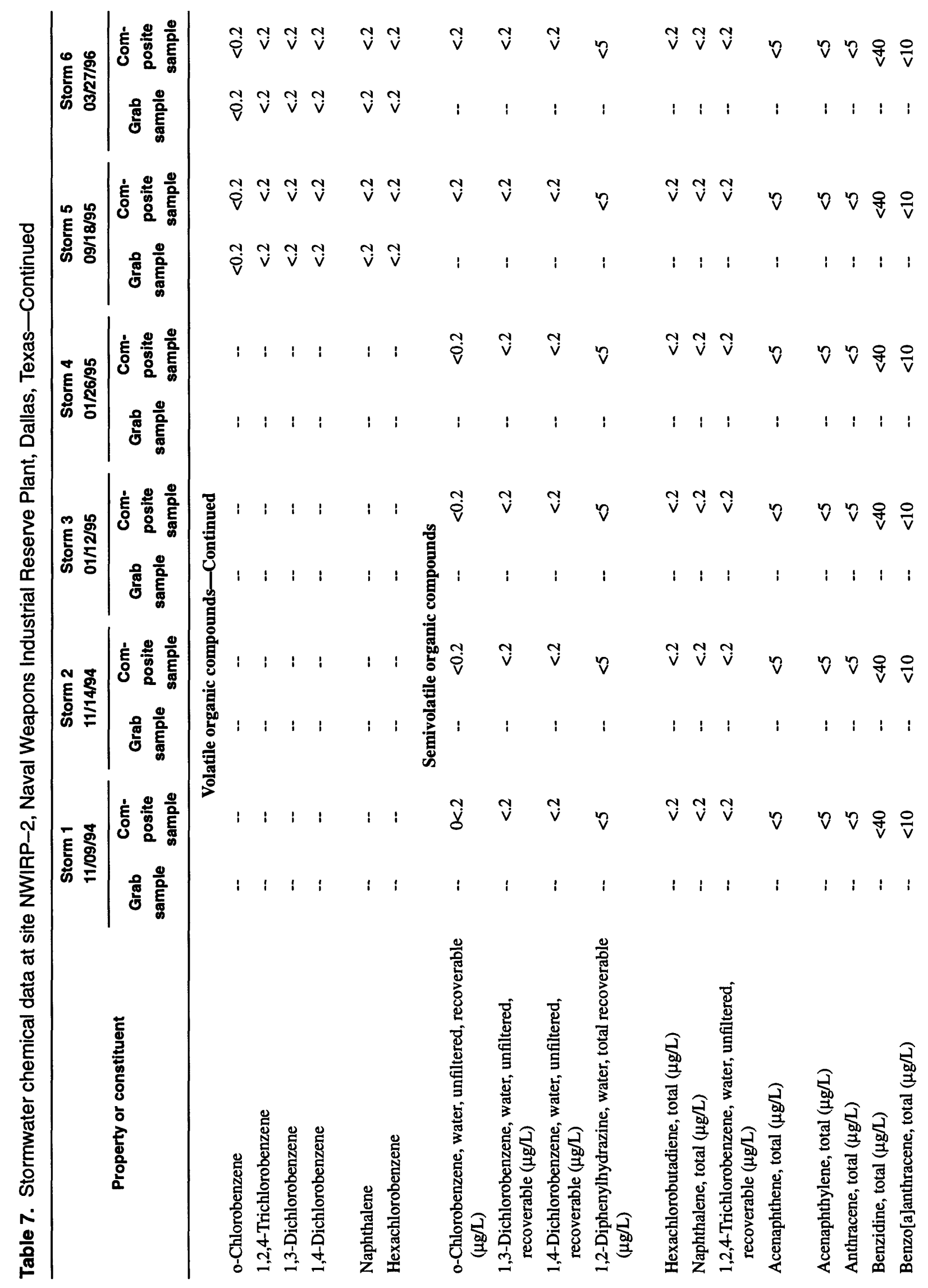




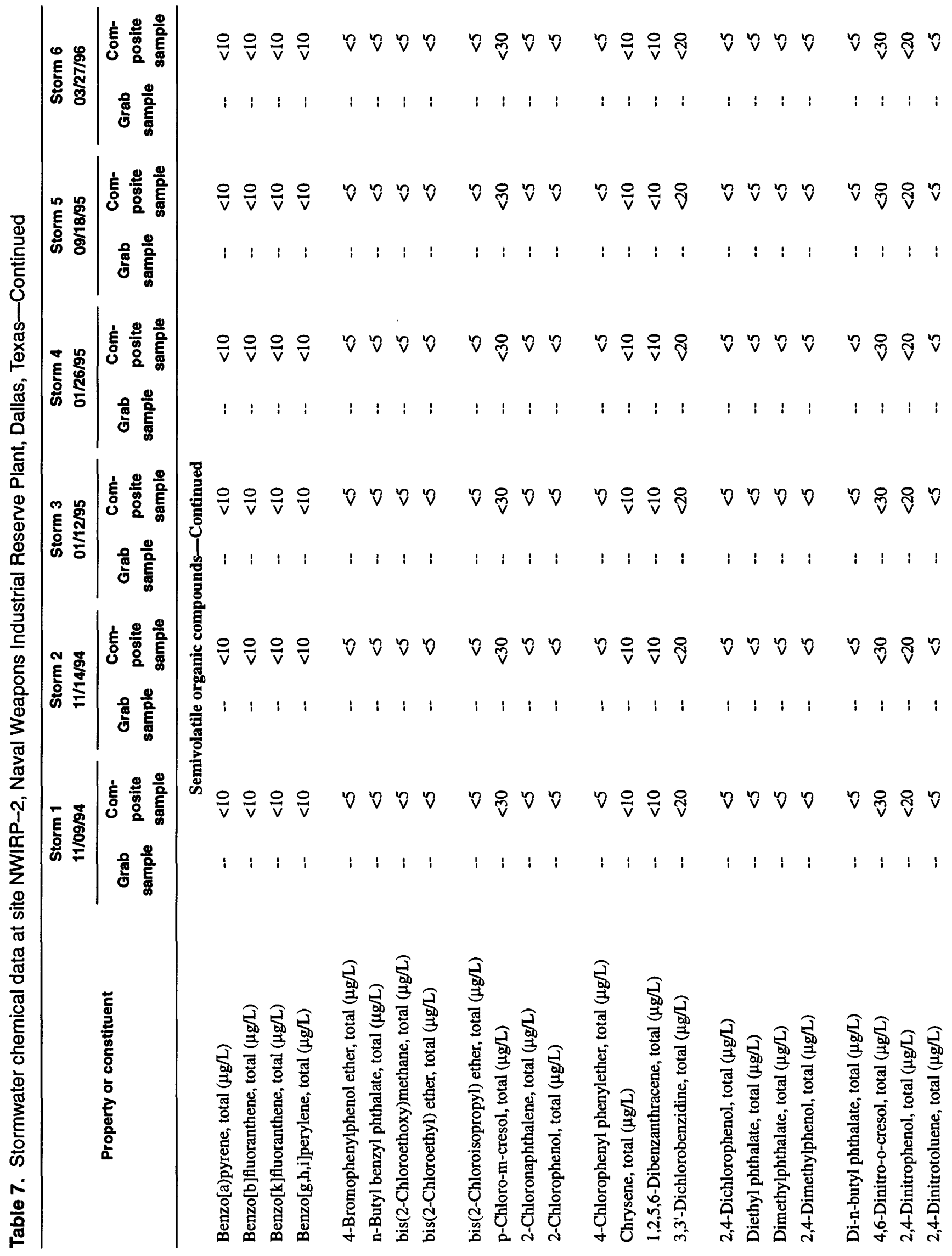




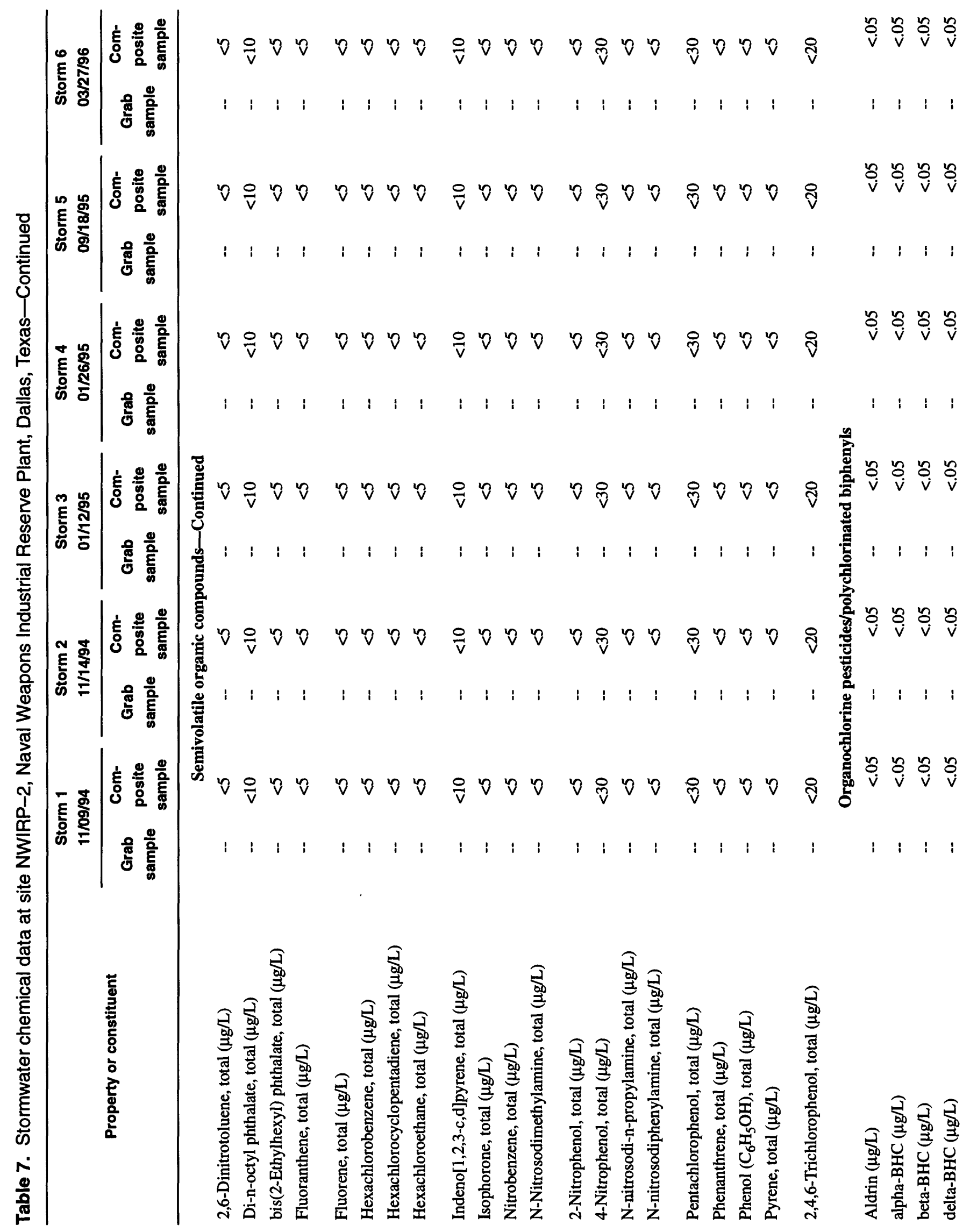




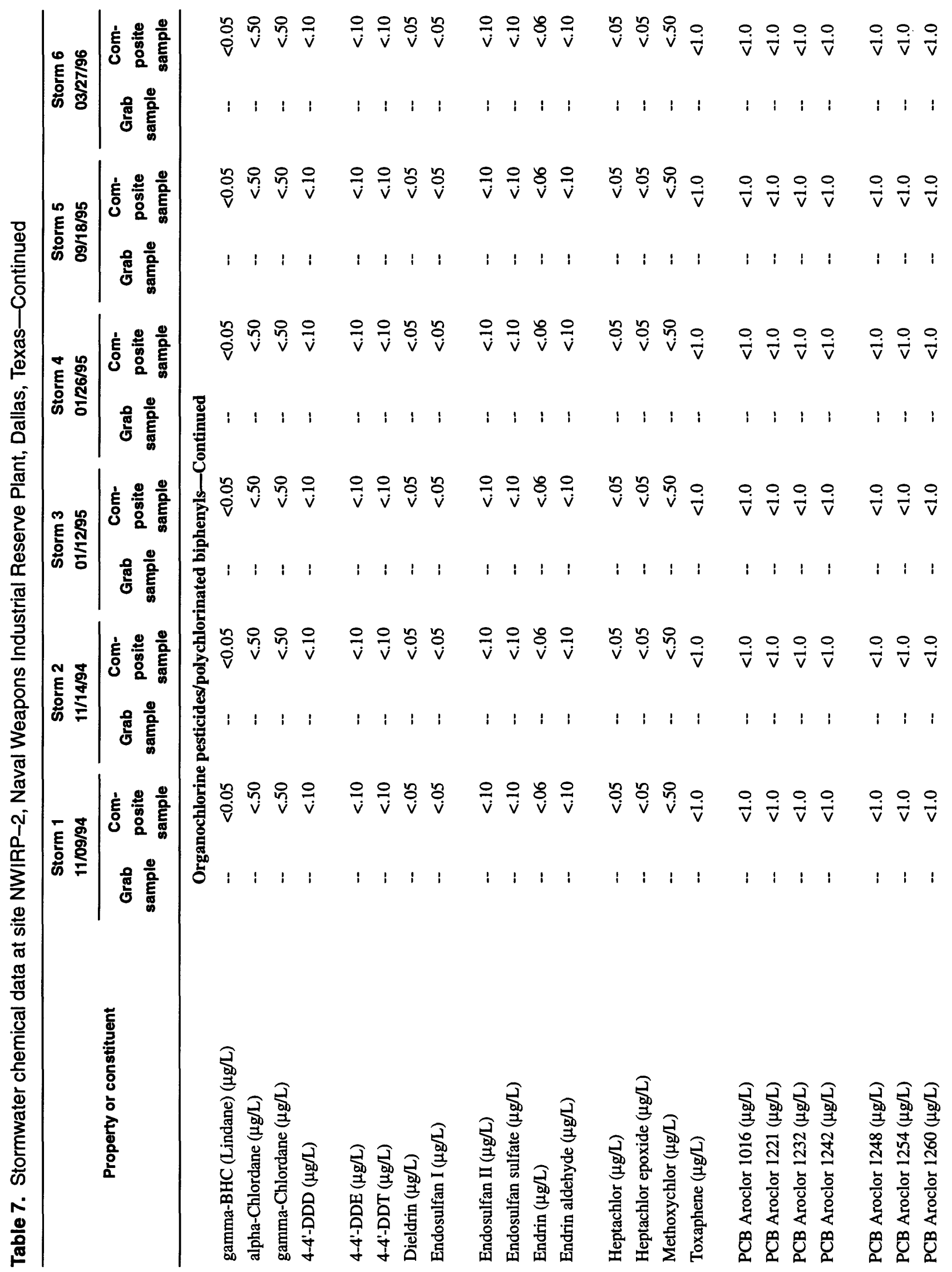




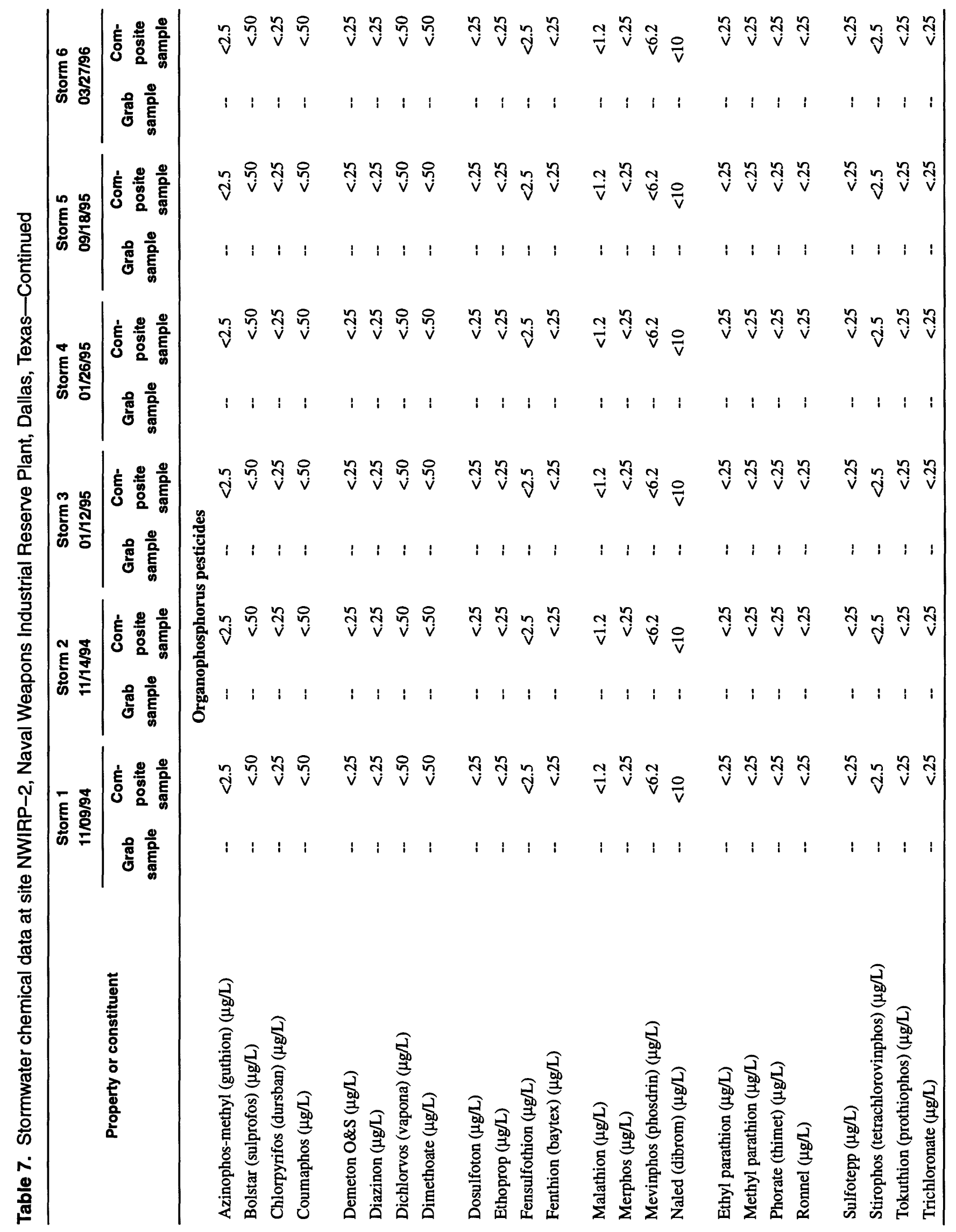




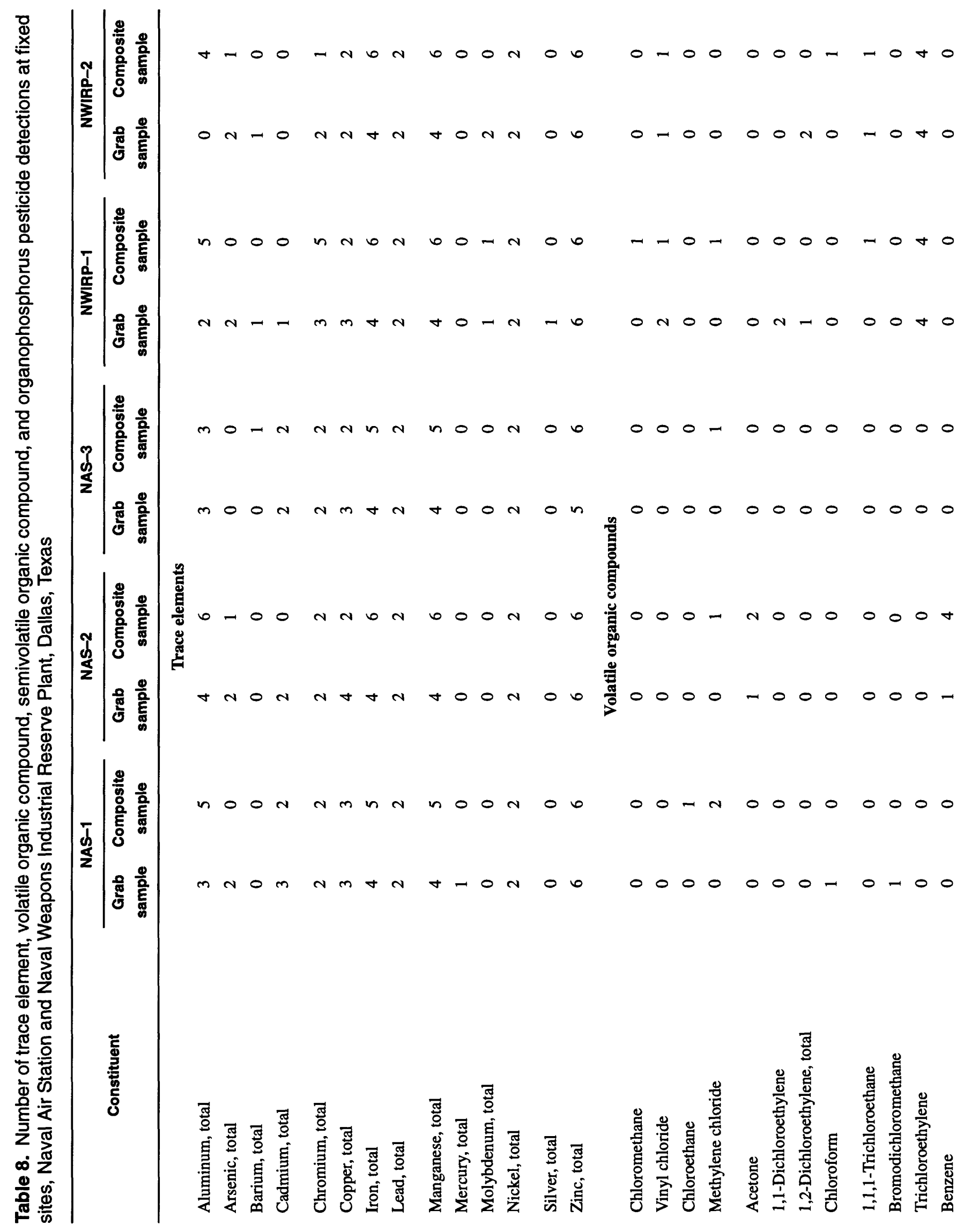




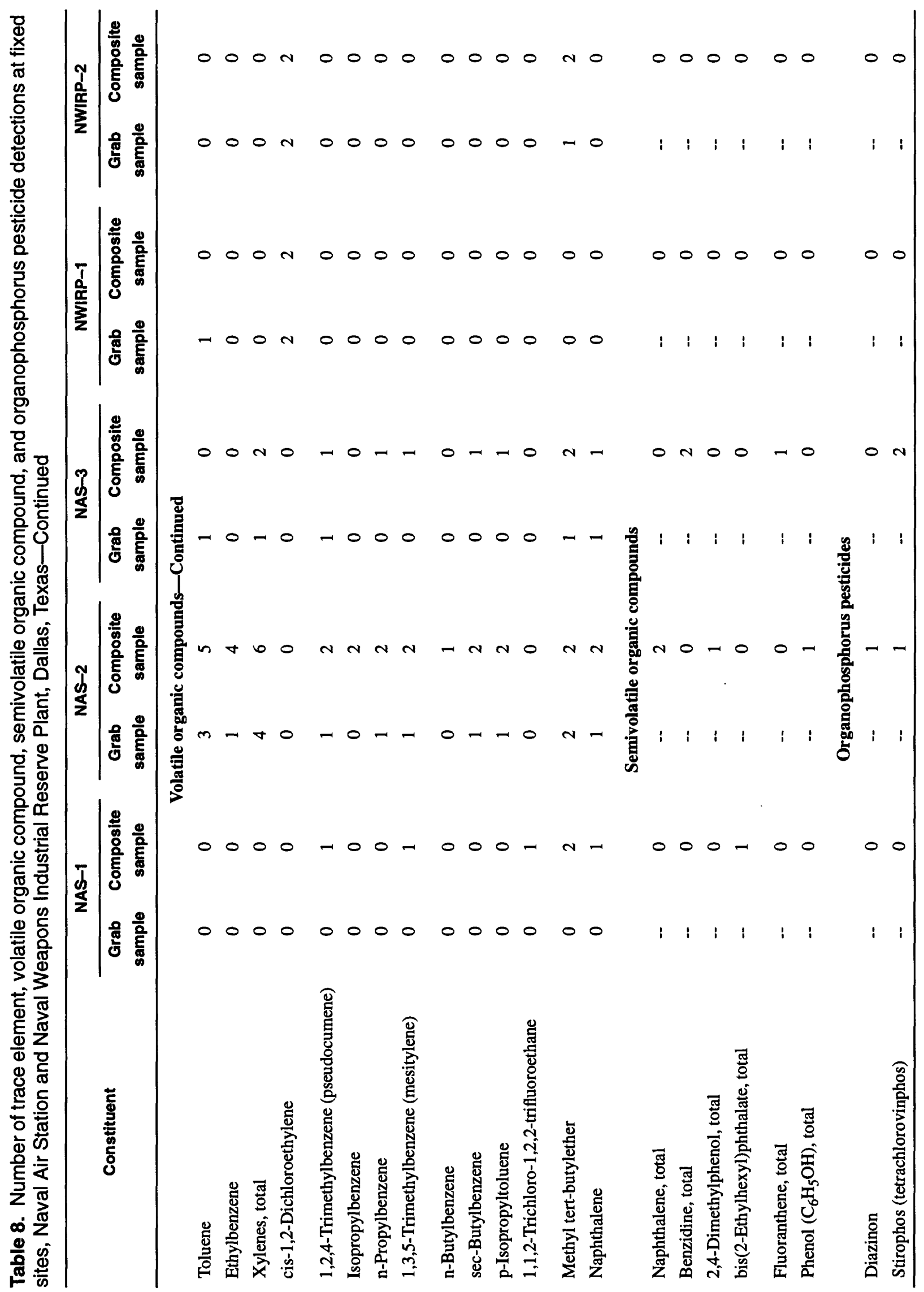




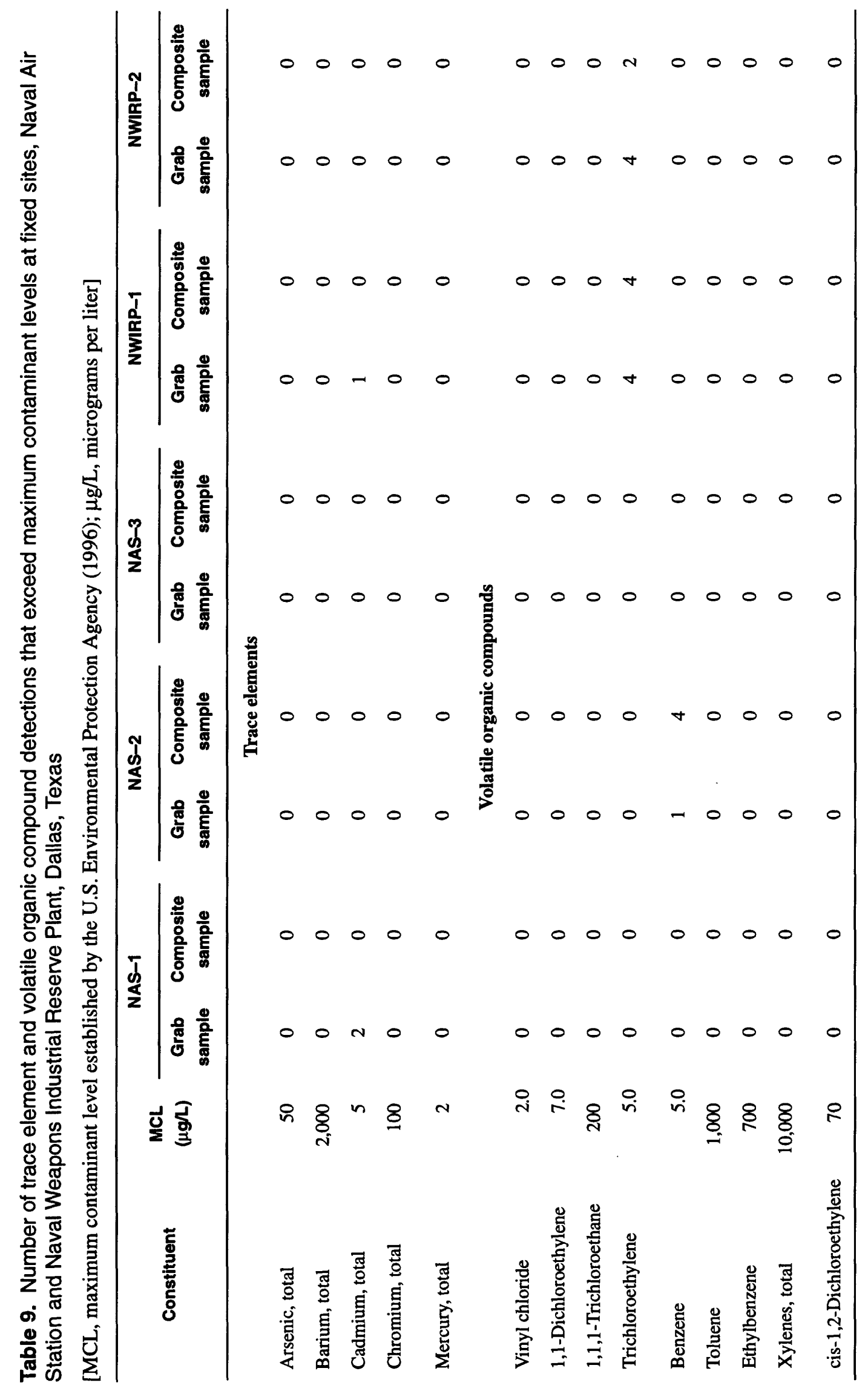




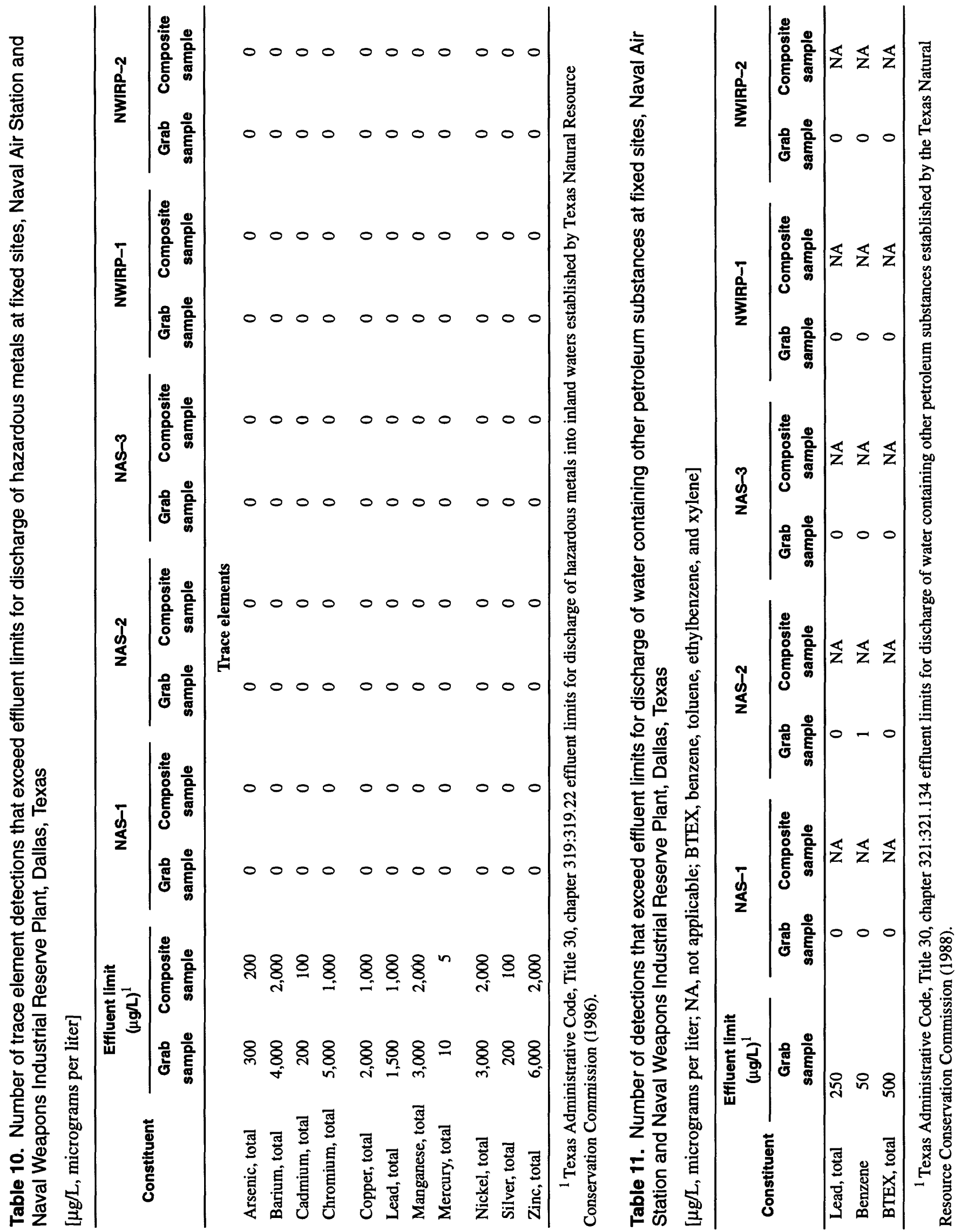




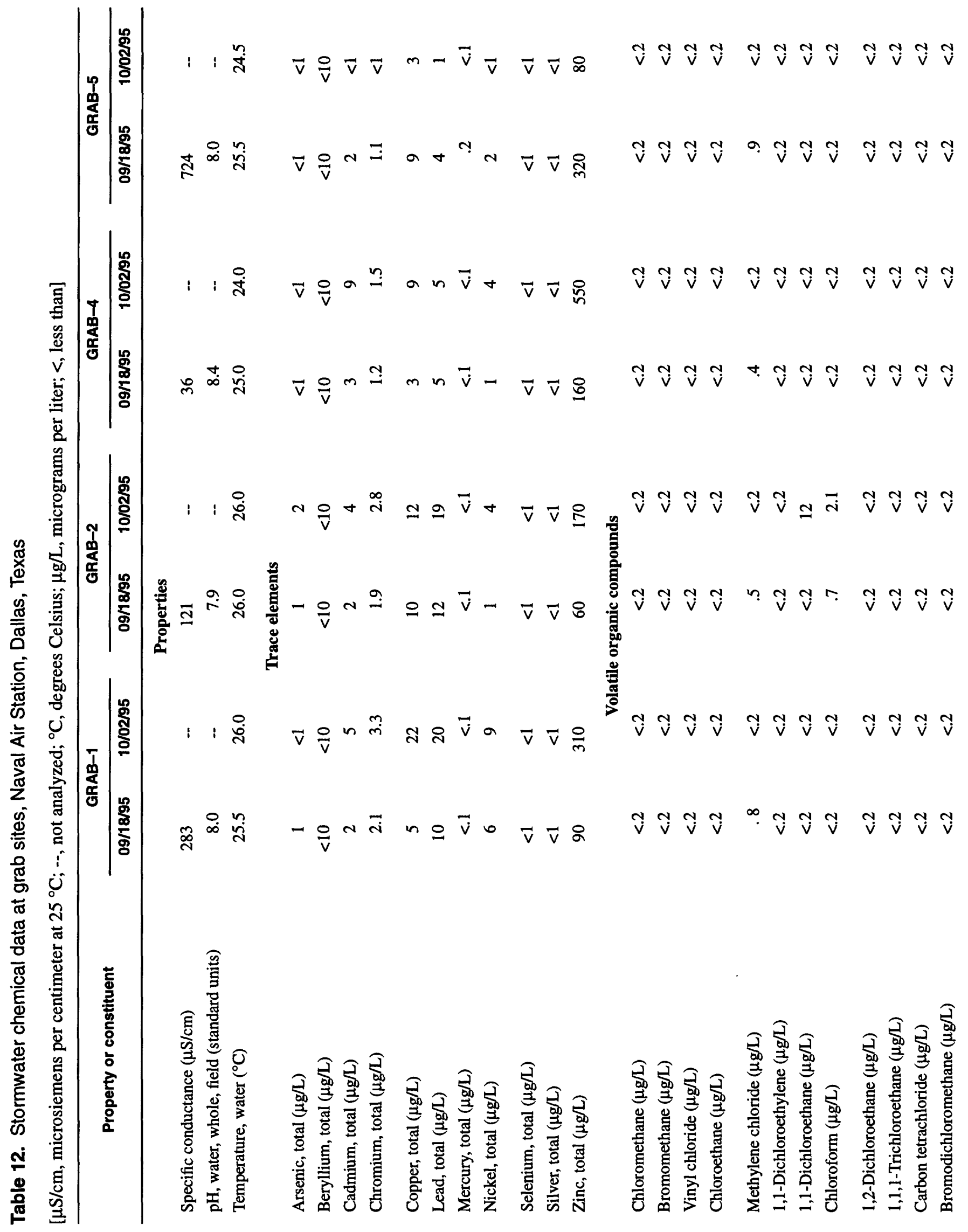




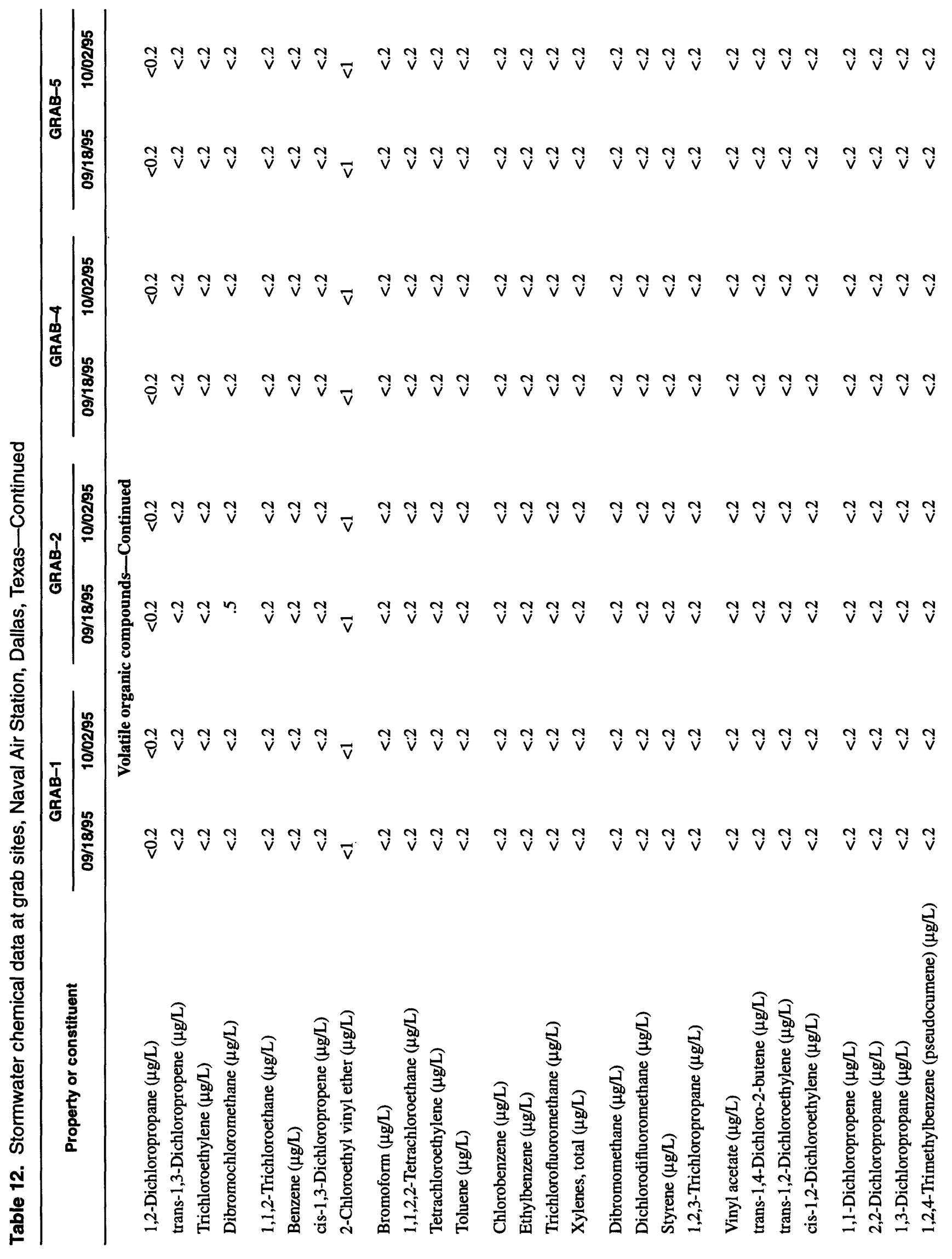




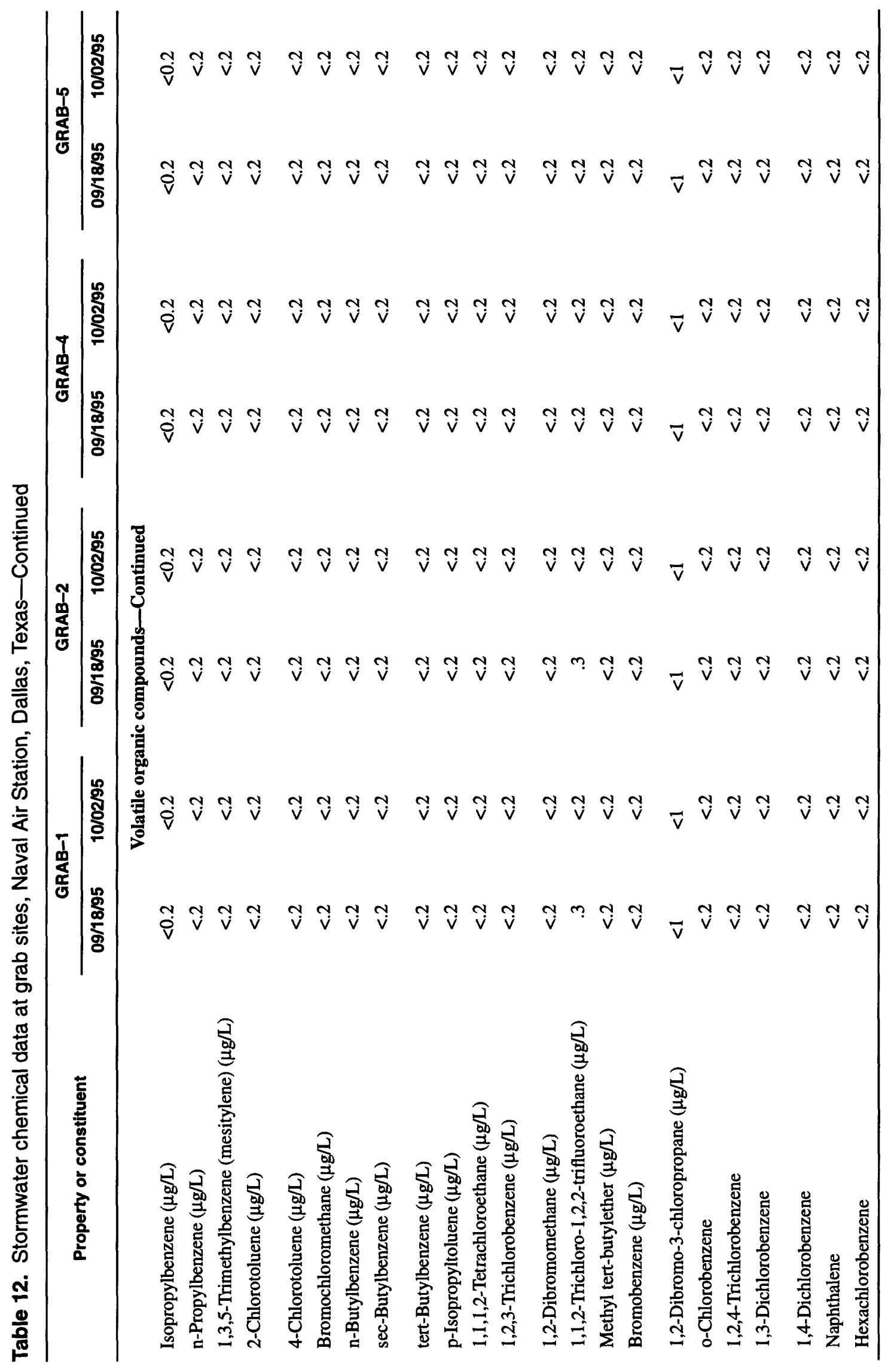




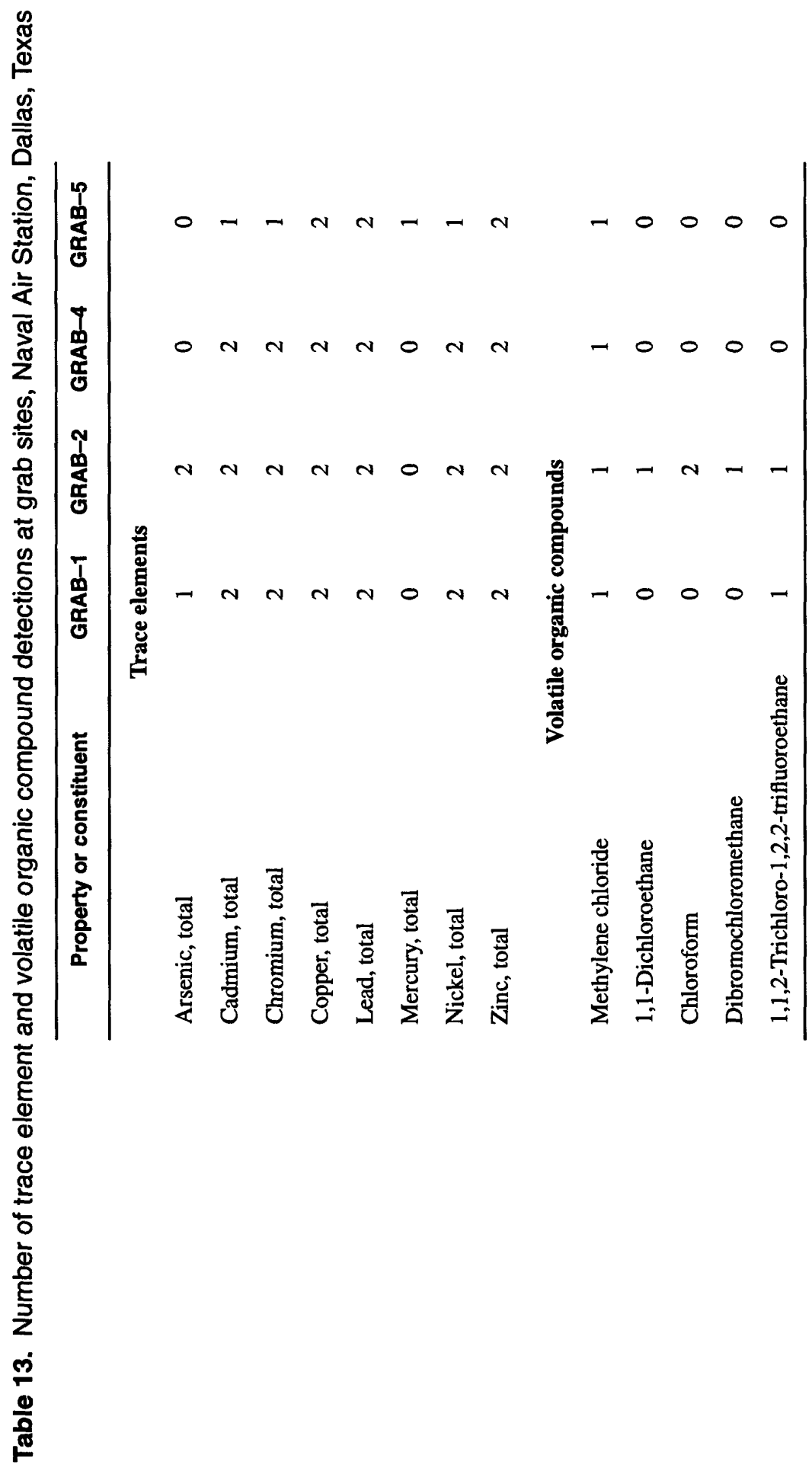




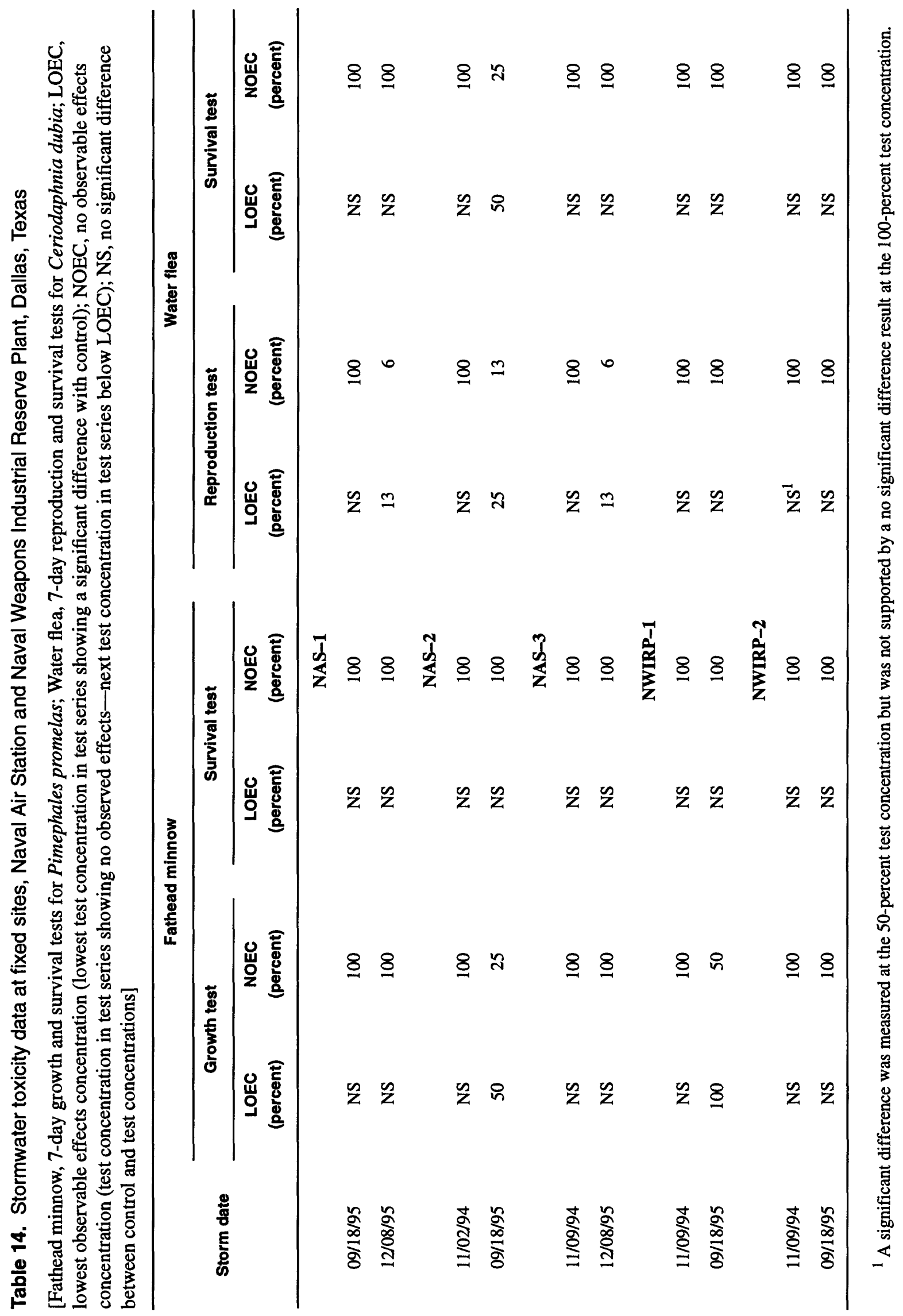




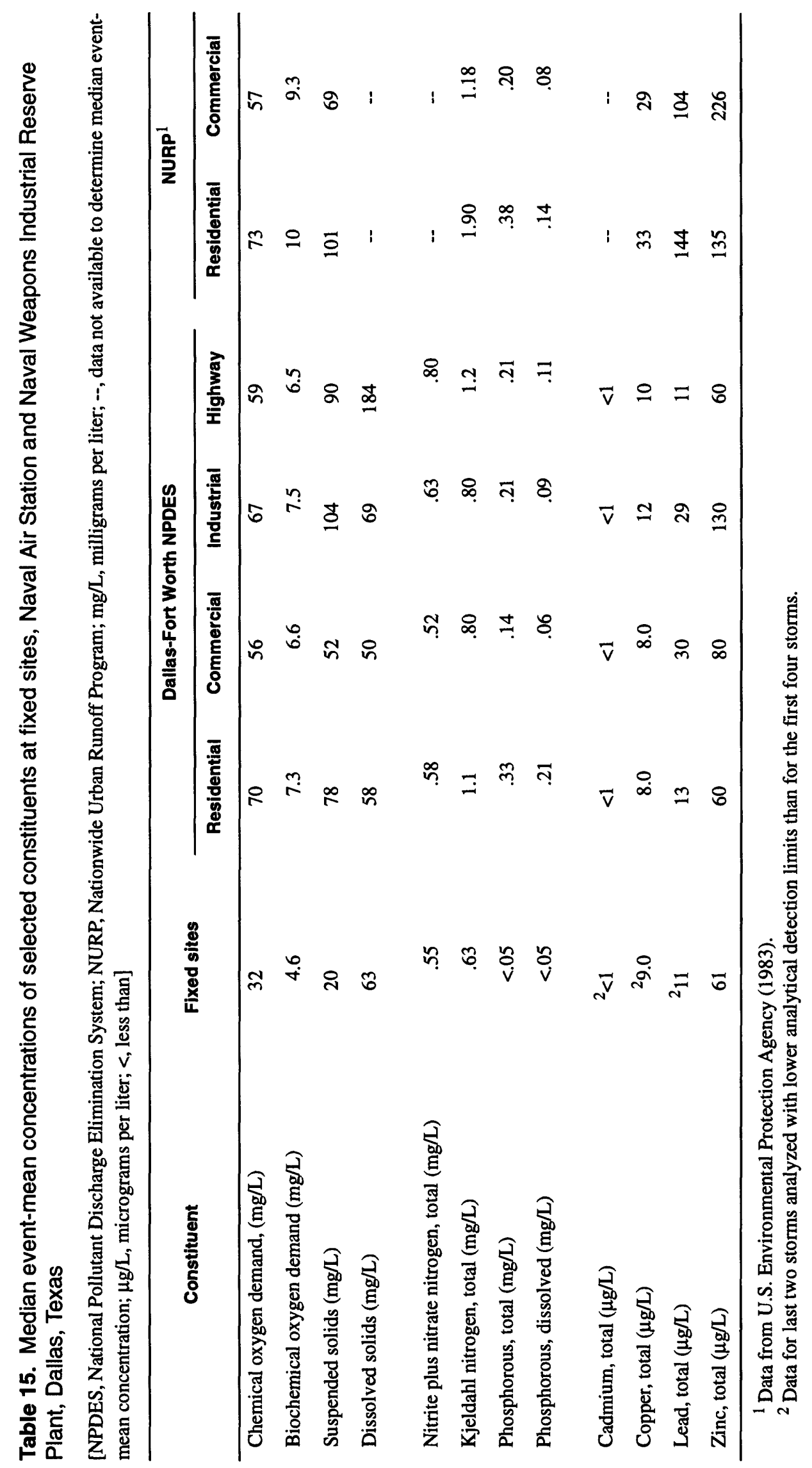

